Pengantar : Prof. Dr. H. Akhyak, M.Ag.

1N
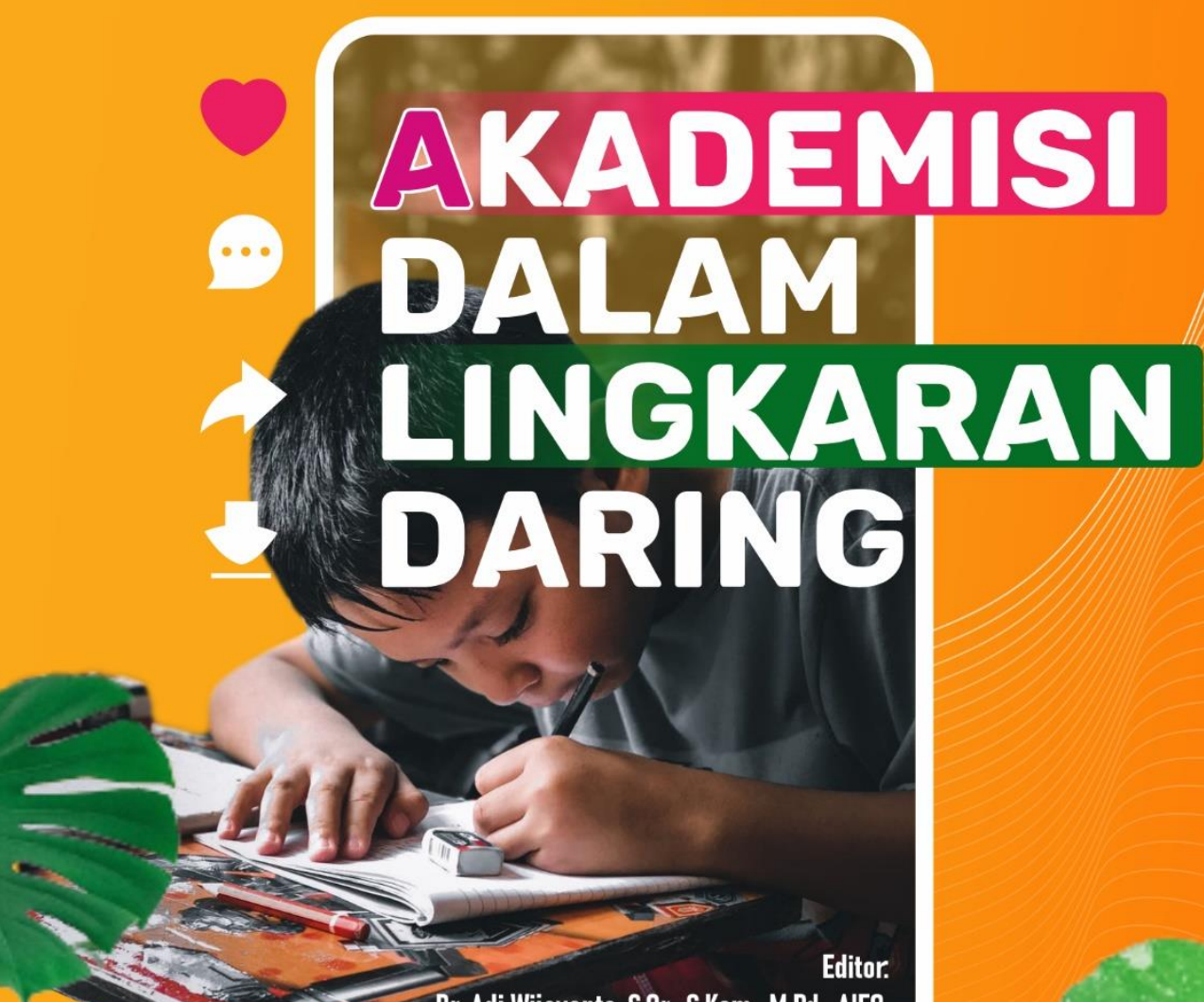

Dr. Adi Wijayanto, S.Or., S.Kom., M.Pd., AlFO. Dr. Nurul Aryanti, M.Pd. Yulianti, S.Sos., M.I.Kom. Dr. Saidna Zulfiqar Bin Tahir, Lc., M.Pd., Ph.D
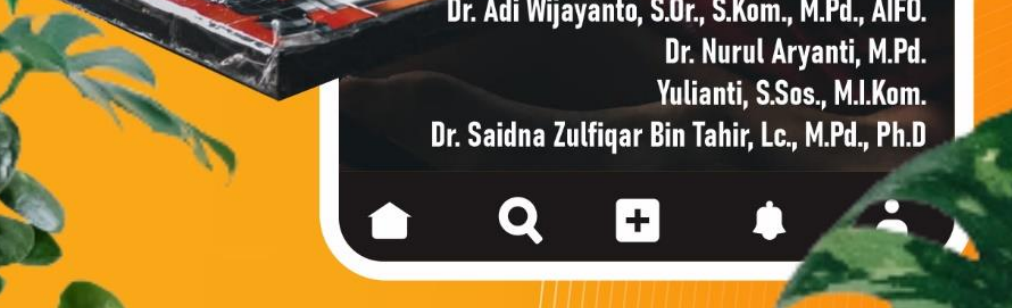

Jonnt Stahaan [ Rora Rilzky Wandini [ Wahab Syakhirul Alim 6. Wahyon Wugroho I Lorena Dara Pưd Karsono [ Nur Faizin I Ahmad Fawaid

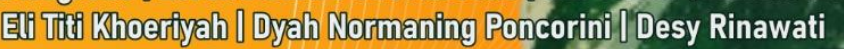
Faricha Andriant ITrie Nadilla I Mochammad Ronaldy Afi Saputra Dwt Martiningsth I Whing Prasetya Kurwilawan I Andriani Paulin Nalle Danni Nursalim [ Topo Yono [ EFni Raster Klau [ Gumilar Mulya

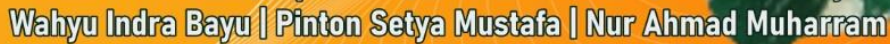

Muhammad Soleh Fudin I Stivt Aryanti I Fegie Rilzzka Mulyana

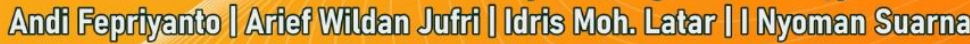


Pengantar:

Prof. Dr. H. Akhyak, M.Ag.

\title{
AKADEMISI DALAM LINGKARAN DARING
}

\author{
Jonni Siahaan - Rora Rizky Wandini - \\ Wahab Syakhirul Alim - Wahyu Nugroho - \\ Lorena Dara Putri Karsono - Nur Faizin - Ahmad Fawaid - \\ Eli Titi Khoeriyah - Dyah Normaning Poncorini- \\ Desy Rinawati - Faricha Andriani - Trie Nadilla - \\ Mochammad Ronaldy Aji Saputra - Dwi Martiningsih - \\ Wing Prasetya Kurniawan - Andriani Paulin Nalle - \\ Danni Nursalim - Topo Yono - Erni Raster Klau - \\ Gumilar Mulya - Wahyu Indra Bayu - \\ Pinton Setya Mustafa - Nur Ahmad Muharram - \\ Muhammad Soleh Fudin - Silvi Aryanti - \\ Fegie Rizkia Mulyana - Andi Fepriyanto - \\ Arief Wildan Jufri - Idris Moh. Latar - I Nyoman Suarna
}

\section{Editor:}

Dr. Adi Wijayanto, S.Or., S. Kom., M.Pd., AIFO.

Dr. Nurul Aryanti, M.Pd.

Yulianti, S.Sos., M.I.Kom.

Dr. Saidna Zulfikar Bin Tahir, Lc., M.Pd., Ph.D 


\section{Akademisi dalam Lingkaran Daring}

Copyright (C) Jonni Siahaan, dkk., 2021

Hak cipta dilindungi undang-undang

All right reserved

Editor: Adi Wijayanto, dkk.

Layouter: Muhamad Safi'i

Desain cover: Dicky M. Fauzi

Penyelaras akhir: Saiful Mustofa

$\mathrm{x}+238 \mathrm{hlm}: 14 \mathrm{x} 21 \mathrm{~cm}$

Cetakan: Pertama, Juni 2021

ISBN: 978-623-6704-99-8

\section{Anggota IKAPI}

Hak cipta dilindungi undang-undang. Dilarang memplagiasi atau memperbanyak seluruh isi buku ini tanpa izin tertulis dari penerbit.

Diterbitkan oleh:

\section{Akademia Pustaka}

Perum. BMW Madani Kavling 16, Tulungagung

Telp: 081216178398

Email: redaksi.akademia.pustaka@gmail.com

Website: www.akademiapustaka.com 


\section{Kata Pengantar}

Droses pendidikan yang sudah terbiasa dilakukan di sekolah dan perguruan tinggi harus mampu juga diwujudkan ketika harus belajar dari rumah. Kondisi ini tentu menjadi tantangan bagi profesi bidang pendidikan. Buku dengan judul "AKADEMISI DALAM LINGKARAN DARING" ini hadir tentunya untuk menjadi salah satu referensi bagaimana seharusnya para profesi bidang pendidikan menjalankan profesinya. Prediksi berbagai pihak bahwa belajar di rumah secara digital (online) diperkirakan relatif tidak dapat mewujudkan hasil belajar yang optimal, seperti diketahui bahwa hasil belajar di sekolah secara umum diukur melalui tiga domain yaitu kognitif (pengetahuan), psikomotor (keterampilan atau penguasaan gerak atau keahlian) dan afektif (perubahan sikap atau perilaku atau kharakter). Domain kognitif, afektif dan psikomotor diyakini masih dapat diwujudkan melalui online meskipun relatif kurang optimal hasil belajarnya.

Terobosan yang banyak disarankan melalui berbagai metode belajar daring (dalam jaringan) atau secara digital (online) di tengah badai Covid-19. Upaya untuk mempertahankan kualitas pendidikan yang diukur dari tingkat capaian hasil belajar di tengah Pandemi Covid19 tentu menjadi target dari para penulis Bunga Rampai ini yang dijabarkan dalam berbagai topik sebagaimana tututan kurikulum Merdeka Belajar di sekolah dimana ketiga domain tersebut saling terkait untuk mewujudkan capaian hasil belajar. Secara garis besar ukuran yang dapat digunakan dari tiga domain tersebut 
adalah meningkatnya pengetahuan murid melalui apa yang dipelajari. Hal ini tidak luput dari pemikiran penulis untuk membahasnya sehingga buku Bunga Rampai menjadi menarik bagi setiap pembaca.

Demikianlah beberapa hal yang dapat disampaikan sebagai penguatan dan penutup kata pengantar pada buku ini, semoga dengan hadirnya buku bunga rampai ini dapat menambah wawasan dan pengetahuan para pembaca secara khusus para guru, dosen dan pemerhati pendidikan serta kami berharap agar terus-menerus dapat menuliskan pemikiran empirisnya dalam buku bunga rampai lainnya. Buku adalah jendela dunia, dan kelak buku ini menjadi harta warisan yang sangat berharga buat tunas bangsa Indonesia di masa akan datang.

Tulungagung, 5 Mei 2021

Prof. Dr. H. Akhyak, M.Ag. Direktur Pascasarjana UIN Sayyid Ali Rahmatullah Tulungagung 


\section{Daftar Isi}

KATA PENGANTAR............................................................. ii

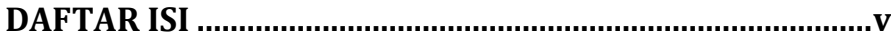

\section{BAB I}

EKSTRAORDINARY PEMBELAJARAN DARING

PARADIGMA BARU GURU DALAM

PENGEMBANGAN PENDIDIKAN DI ERA PANDEMI

COVID-19

Prof. Dr. Jonni Siahaan.,M.Kes.,AIFO. \& Dr. Rif'iy

Qomarullah.,S.Pd.,M.Or. (Universitas Cenderawasih

Papua)

“MIKIR” DI MASA PANDEMI COVID-19

Rora Rizky Wandini, M.Pd.I. (UIN Sumatera Utara

Medan)

KEMANDIRIAN BELAJAR BAHASA INGGRIS

MELALUI ARTIFICIAL INTELLIGENCE PADA MASA

PANDEMI COVID-19.

Wahab Syakhirul Alim, M.Pd. (IAIN Madura)

STRATEGI GURU DALAM MEMANFAATKAN PEMBELAJARAN BERBASIS DIGITAL PADA KURIKULUM DARURAT

Wahyu Nugroho, M.Pd. (STKIP PGRI Trenggalek)

PEMULIHAN UMKM PASCA PANDEMI DENGAN AKSELERASI DIGITALISASI

Lorena Dara Putri Karsono. M.M (IAIN Kudus) 
MELAWAM PANDEMI DENGAN SCREEN RECORDER TOOL UNTUK MEMBUAT VIDEO

PEMBELAJARAN

Dr. Nur Faizin, MA. \& Dr. M. Wahid Dariyadi, M.Pd.I, \& Muhammad Lukman Arifianto, SS., MA. (Universitas Negeri Malang)

PENGUATAN KOMPETENSI GURU PADA MASA PANDEMI COVID-19.

Ahmad Fawaid, M.Pd.I (Fakultas Tarbiyah IAIN Madura)

OPTIMALISASI PENDEKATAN PEMBELAJARAN STEM SECARA DARING SAAT PANDEMI

Eli Titi Khoeriyah, S. Pd.M.Sc. (MAN 2 Cilacap)

KOLABORASI ANTARA GURU DAN ORANG TUA DALAM PROSES PEMBELAJARAN SELAMA PANDEMI

Dyah Normaning Poncorini, S.Pd (SMP Negeri 06 Batu)

MEMBIASAKAN HAL YANG TIDAK BIASA DALAM MATA PELAJARAN PRODUK KREATIF DAN KEWIRAUSAHAAN

Desy Rinawati, S.Pd. (SMKN 1 Dringu, Probolinggo)

BAB II

TANTANGAN DAN PERMASALAHAN SELAMA PEMBELAJARAN DARING

APLIKASI KONSELING “MY COUNSELOR” UNTUK MENJAWAB TANTANGAN PEMBELAJARAN DARING DI MASA PANDEMI COVID-19 81

Faricha Andriani, M.Psi (Institut Agama Islam Negeri (IAIN) Kudus)

MENGAJAR AKUNTANSI DI ERA NEW NORMAL ....87 Trie Nadilla, M.Si,Ak,CA,CAPF (IAIN Lhokseumawe) 
PELUANG DAN TANTANGAN PEMBELAJARAN DARING MASA PANDEMI COVID-19 93

Mochammad Ronaldy Aji Saputra, S.Pd. (MAN Sumenep)

TANTANGAN PERAN GURU DALAM E-LEARNING: MANDIRI BELAJAR DI MASA PANDEMI COVID-19 101

Dwi Martiningsih, S.Psi, M.A. (Lajnah Pentahsihan Mushaf Al-Qur'an (LPMQ) Kementerian Agama RI)

WABAH COVID-19 MEMBERIKAN ANCAMAN MENJADI SEBUAH PELUANG DALAM PARADIGMA PENDIDIKAN 4.0: SOLUSI PEMBELAJARAN JARAK JAUH 109

Wing Prasetya Kurniawan, M.Pd. (Universitas Nusantara PGRI Kediri)

KENYAMANAN BELAJAR SISWA MENGHADAPI PEMBELAJARAN ONLINE DI MASA PANDEMIC COVID-19.

Andriani Paulin Nalle (Universitas Nusa Cendana)

KAJIAN MAHASISWA DARING: SOLUSI

PENDIDIKAN KARAKTER DI MASA PANDEMI .... 125

Danni Nursalim, Lc. Dipl. I.S. (Yayasan Bakti Anam Harning (BINAR) Bandung)

PEMBELAJARAN DARING YANG EKONOMIS DAN BERAHLAK MULIA PADA ERA PANDEMI COVID-19 131

Topo Yono, M.Pd. (Pendidikan Olahraga Universitas Muhammadiyah Jember)

GAMBARAN KEJENUHAN MAHASISWA MENGIKUTI PEMBELAJARAN DARING DI MASA PANDEMI..... 137 Erni Raster Klau (Universitas Nusa Cendana) 
BAB III

ILMU KEOLAHRAGAAN DALAM

PEMBELAJARAN DARING

PENDIDIKAN JASMANI DAN PERSOALAN

OLAHRAGA NASIONAL

Dr. Gumilar Mulya, M.Pd. (Jurusan Pendidikan

Jasmani, FKIP Universitas Siliwangi)

HIGHER ORDER THINKING SKILLS DALAM

PENDIDIKAN JASMANI

Dr. Wahyu Indra Bayu, M.Pd. (Universitas Sriwijaya)

MOTIVASI DAN KEPERCAYAAN DIRI DALAM

MELAKUKAN AKTIVITAS FISIK MELALUI

PEMBELAJARAN DARING 165

Pinton Setya Mustafa, M.Pd (Universitas Islam Negeri

Mataram)

PERAN SPORTS PSYCHOLOGY DALAM

PEMBELAJARAN PENDIDIKAN JASMANI DI MASA

PANDEMI COVID 19

Nur Ahmad Muharram, M.Or. (Universitas Nusantara PGRI Kediri)

MODEL PEMBELAJARAN PORTOFOLIO BERBASIS MEDIA INTERAKTIF SEBAGAI ALTERNATIF PEMBELAJARAN DARING PENDIDIKAN JASMANI OLARAGA DAN KESEHATAN 183

Muhammad Soleh Fudin, M.Pd. (STKIP PGRI

Trenggalek)

STRATEGI PEMBELAJARAN PENDIDIKAN JASMANI

BERBASIS DARING DI ERA NEW NORMAL 193

Silvi Aryanti (Universitas Sriwijaya)

TIPS DAN TRIK MENGAJAR MATA KULIAH

PRAKTIK (PEMBELAJARAN SENAM) SELAMA

PANDEMI

Fegie Rizkia Mulyana, M.Pd. (Universitas Siliwangi) 
EVALUASI PEMBELAJARAN PJOK MELALUI PORTFOLIO ASSESMENT DI MASA PANDEMI ........ 207 Andi Fepriyanto, M.Pd. (STKIP PGRI Sumenep)

IMPLEMENTASI PERMAINAN TRADISIONAL RABKERRABEN SAPE DALAM MENINGKATKAN MOTORIK SISWA DI MASA PANDEMI.................... 215 Arief Wildan Jufri, S.Pd (SDN Pangarangan III Kec. Kota Sumenep)

TEKNIK PRAKTIS BELAJAR PENJASORKES DI MASA PANDEMIC 19

Dr. Idris Moh. Latar, S.Pd, M.Pd. (Program Studi Penjaskesrek FKIP Unpatti)

KESADARAN HUKUM , KESEHATAN MASYARAKAT DALAM AGAMA HINDU DI TENGAH PANDEMI COVID-19 231

I Nyoman Suarna (IAHN Gde Pudja Mataram) 


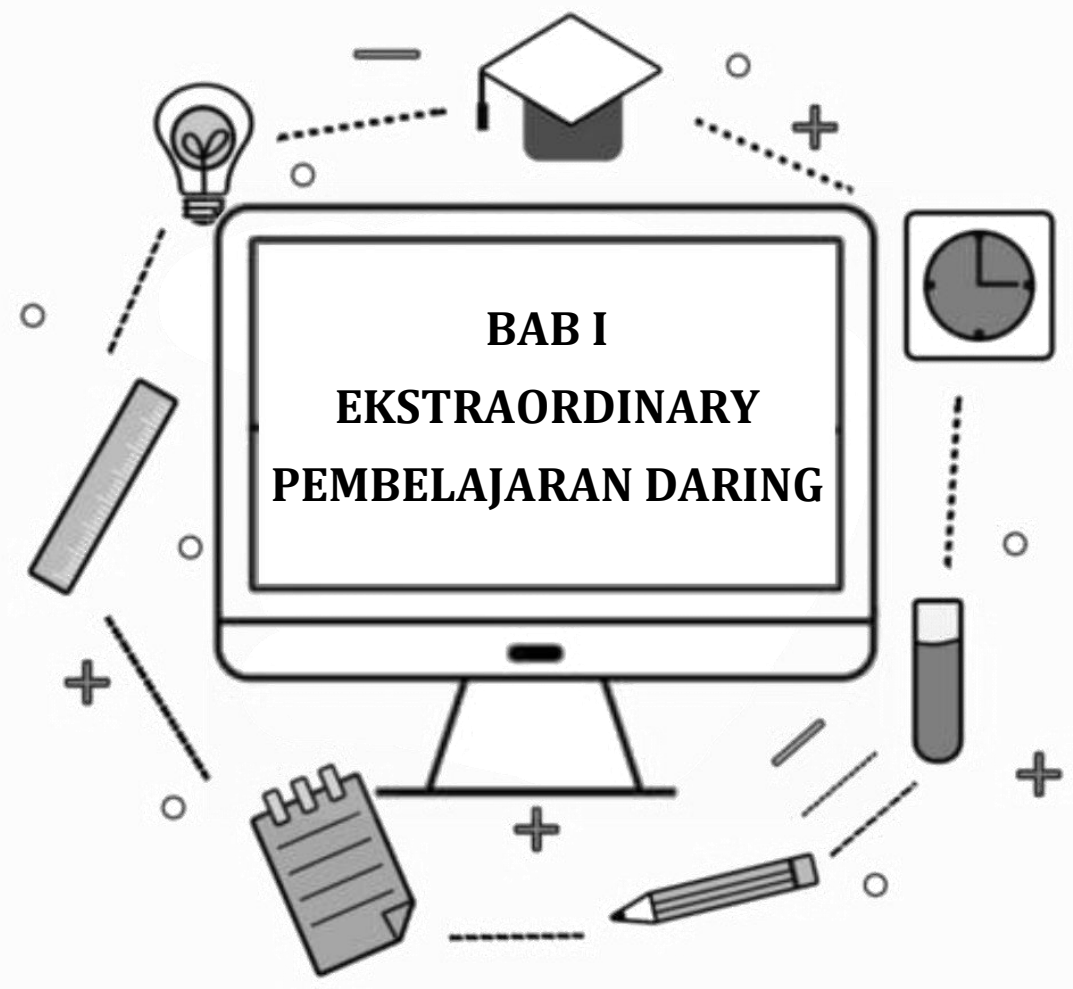





\section{PARADIGMA BARU GURU DALAM PENGEMBANGAN PENDIDIKAN DI ERA PANDEMI COVID-19}

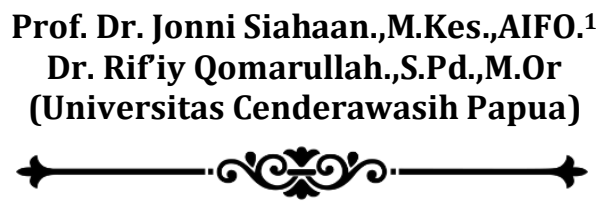

"Pendekatan program merdeka belajar secara sadar dapat membangun paradigma baru baik pada guru maupun murid Paradigma baru guru sebagai loncatan mewujudkan generasi muda bangsa yang kompetitif menuju Indonesia emas 2045"

Presiden Republik Indonesia Bapak Ir. H. Joko
Widodo bersama Menteri Pendidikan dan

1 Penulis lahir di Martubung (Medan), 13 Desember 1965. Beliau Guru Besar/Profesor dalam bidang Ilmu Pendidikan Olahraga Universitas Cendrawasih Papua. Saat ini menjabat sebagai Sekretaris Dewan Pakar Pengurus Pusat ISORI (Ikatan Sarjana Olahraga Indonesia). Tamat SMAN 3 Medan (1984). Strata 1 Pendidikan Kepelatihan FPOK/IKIP Medan (1990). Strata 2 Gizi Masyarakat Pascasarjana Universitas Airlangga/Unair Surabaya (1999). Strata 3 Pendidikan Olahraga Pascasarjana Universitas Negeri Semarang (2008). 
Kebudayaan Riset dan Teknologi, Bapak Nadiem Anwar Makarim pada Hari Pendidikan Nasional (Hardiknas) tanggal 2 Mei 2021 mengambil Tema "Serentak Bergerak Wujudkan Merdeka Belajar". Program merdeka belajar ini bermaksud untuk mempercepat terjadinya loncatan-loncatan dalam pengembangan pendidikan di Indonesia. Loncatan yang dimaksud adalah mengubah kebiasaan dalam dunia pendidikan yang biasa-biasa saja menjadi sesuatu yang luar biasa dan berdampak pada kemajuan seluruh rakyat Indonesia.

Kemajuan teknologi digital harus dapat dimanfaatkan untuk melakukan loncatan-loncatan dalam penyelenggaraan pendidikan terutama dalam proses belajar baik di sekolah maupun di rumah seperti saat ini dalam kondisi daring (online), tidak boleh biasabiasa saja, tetapi harus ada sesuatu yang baru atau yang luar biasa sebagai wujud dari pengembangan pendidikan melalui metode belajar, gaya mengajar, materi ajar, pemanfaat media belajar dan sumber belajar yang variatif dan lain-lain dan semuanya harus dapat dioptimalkan dengan target belajar adalah murid memiliki kecerdasan, kompetensi, berakhlak mulia, berkharakter aktif, kreatif dan inovatif, sebagai modal beradaftasi dengan kemajuan zaman.

Serentak bergerak mewujudkan merdeka belajar bermaksud agar seluruh generasi muda bangsa Indonesia memiliki tingkat kecerdasan atau keahlian yang relatif sama, meskipun disadari bahwa untuk wilayah tertentu di Nusantara ini akan mendapatkan kesulitan berbeda dalam mensikapi program merdeka belajar. Meskipun demikian sangat diharapkan melalui merdeka belajar secara perlahan tapi pasti seluruh generasi bangsa Indonesia dapat mengikuti setiap kemajuan yang terjadi sebagai akibat dari 
perkembangan revolusi Industri 4.0 yang ditandai dengan lahirnya teknologi digital dan robotik yang kecepatan kerjanya masif dan sangat cepat bahkan dapat menggantikan sekian banyak pekerjaan profesional manusia.

Semua bangsa di dunia termasuk Indonesia, mau tidak mau harus menghadapi cepatnya dan canggihnya kemajuan teknologi digital. Sistem kerja digital yang sangat canggih dan akan semakin canggih, secara sadarmenuntut kecepatan manusia berpikir dan bertindak secara profesional. Di era kemajuan teknologi digital ini, mau tidak mau manusia harus dapat beradaptasi, dan apabila tidaksanggup atau tidak mau maka dengan sendirinya akan terlindas menjadi insani yang tak berdaya. Perkembangan digital tidak dapat dihentikan dan akan terus berkembang bahkan dapat melebihi kemampuan nalar manusia. Olehkarena itu, loncatan pengembangan pendidikan harus terus menerus dilakukan secara masif dan sangat cepat. Segala sesuatu yang sudah terbiasa dilakukan dalam dunia pendidikan dan hasilnya masih biasa-biasa saja, harus secepatnya diubah untuk menghasilkan sesuatu yang baru.

Merdeka belajar adalah program kebijakan baru Pemerintah RI yang diwujudkan oleh Mendikbud-Ristek dengan maksud untuk melakukan loncatan yang tinggi dalam dunia pendidikan. Ada banyak program pendidikan yang dikembangkan melalui program merdeka belajar. Posisi guru dalam program merdeka belajar ini sebagai penggerak, dengan kata lain guru berada digarda terdepan dalam pengembangan pendidikan. Guru dengan kemerdekaan berpikir dan bertindak menghasilkan sesuatu yang baru dan pengembangannya dilakukan peserta didik. Merdeka belajar pada prinsipnya memberi kebebasan bagi guru 
dan murid untuk berproses memenuhi tuntutan kurikulum sekolah dan yang juga harus mengalami perubahan mengikuti kemajuan teknologi industri 4.0 baik saat ini dan dimasa akan datang. Guru sangat dituntut kebebasannya mewujudkan program merdeka belajar dengan merdeka berpikir dan bertindak dan selanjutnya diikuti anak didik. Artinya guru yang harus berani memulai berbuat sesuatu, bagaimana mendisain proses belajar yang baik dan mampu memotivasi anak didik untuk turut berpikir dan bertindak secara merdeka dan mengembangkannya dalam proses belajarnya. Dalam konteks ini, guru harus memiliki paradigma baru atau pemikiran baru yang maju atau gagasan yang selalu berkembang dalam mengikuti setiap kemajuan teknologi dan merelasikannya dengan tuntutan kompetensi dasar dalam kurikulum sekolah.

Program merdeka belajar di era Pandemi Covid-19 ini sebaiknya dapat diwujudkan tidak hanya di dalam gedung atau ruangan kelas tetapi juga bisa di luar gedung atau ruangan kelas (outing class). Program merdeka belajar ini sesungguhnya memberikan kesempatan seluas-luasnya kepada murid untuk berdiskusi dengan guru dan posisi murid tidak hanya mendengarkan penjelasan guru, tetapi diberi kebebasan untuk menggali berbagai informasi dari berbagai sumber belajar terkait dengan apa yang sedang dipelajari. Proses belajar seperti ini secara langsung akan membentuk sumber daya manusia yang unggul dan berkharakter berani, mandiri, cerdas (smart), bergaul baik, beradap, berprilaku sopan santun, mampu berkompetisi tanpa beban psikis karena dalam proses belajar di sekolah, tidak mengandalkan sistem ranking.

Berdasarkan penjelasan diatas berarti pendekatan program merdeka belajar secara sadar dapat membangun paradigma baru baik pada guru maupun 
murid. Kondisi ini tentu membuat Proses belajar lebih nyaman, karena setiap anak didik diberi kebebasan secara mandiri mengembangkan potensi dirinya sesuai dengan bakat dan kecerdasannya. Sebagai akibat dari program merdeka belajar ini tentu sudah tidak diperlukan lagi ujian nasional yang cenderung menyamaratakan semua bakat dan kecerdasan murid, yang sesungguhnya masing-masing berbeda. Ujian nasional selama ini digunakan untuk menentukan kelulusan peserta didik, akibatnya peserta didik yang tidak memiliki kecerdasan dalam mata pelajaran yang diujikan di ujian nasional sangat mungkin tidak lulus.

Perubahan berpikir kearah pengembangan potensi bakat dan kecerdasan murid dengan pendekatan merdeka belajar dipastikan menimbulkan paradigma baru baik pada guru maupun murid. Kebebasan berpikir pada murid untuk mengembangkan potensi dan kecerdasannya akan membuatnya mampu beradaftasi dengan perkembangan Industri 4.0. Dunia ini seakan terbuka lebar tanpa batas dan seakan hampir tidak ada yang tersembunyi.Sebagai dampaknya kondisi riil di negara lain dapat dilihat oleh semua manusia di muka bumi, termasuk setiap kemajuan teknologi di negara lain. Sebagai dampak lain dari kemajuan digital adalah sumber materi belajar tersedia cukup banyak, semua ada dalam google. Di era digital ini sangat dituntut kemampuan adaftasi anak didik dengan kecepatan sistem kerja digital. Selanjutnya anak didik mendapat fasilitas untuk mengembangkan potensinyadengan cepat baik potensi akademik maupun suatu kompetensi atau keahlian khusus yang ingin dimilikinya (skill). Kemampuan anak didik memiliki sebuah kompetensi (skill) merupakan salah satu parameter keberhasilan memanfaatkan digital. 
Paradigma baru yang dituntut di era pandemi Covid19 dan kemajuan digital, salah satunya berupa perubahan berpikir seperti bagaimana bertahan hidup dalam kondisi pandemi Covid-19. Dalam dunia pendidikan diperlukan perubahan berpikir, bagaimana proses belajar bisa berlangsung dengan baik meskipun muridbelajar di rumah secara daring (online), dan sudah banyak informasi yang diperoleh melalui webinar bahwa belajar secara daring sebagai akibat dari pandemi Covid-19 sangat menjenuhkan baik pada guru maupun murid, walaupun guru dan murid berusaha mencari tempat melaksanakan dari di tempat-tempat yang nyaman sekalipun. Proses belajar secara tatap muka adalah yang terbaik untuk meningkatkan mutu pendidikan di muka bumi ini. Paradigma manusia di dunia saat ini secara bertahap sudah berubah dari kebiasaannya selama Pandemi Covid-19 ini.Perubahan sikap dan perilaku ini harus disikapi dengan munculnya paradigma baru baik pada guru maupun murid yang lahir dari aturan-aturan yang diberlakukan dalam protap kesehatan selain wajib mendapatkan vaksin. Semua insan manusia pastilah sangat menginginkan hidup sehat dan bugar tanpa covid. Olehkarena itu sepanjang protap kesehatan itu mampu membuat manusia sehat dan bugar, dapat dipastikan akan menjadi social culture di masyarakat. Kepatuhan dan kesadaran untuk mematuhi protap covid-19 secara sadar akan menjaga diri dari masuknya virus-virus yang banyak di udara, selain virus Covid-19 tersebut.

Paradigma baru seperti selalu cuci tangan, berolahraga secara teratur, mengkonsumsi makanan yang sehat dan bergizi, menjaga kebersihan tubuh, pakai masker setiap berada di luar rumah, selalu menjaga jarak ketika sedang berdiskusi, dan lain-lain akan sangat baik bila menjadi suatu kebiasaan (budaya) yang baru sebagai oleh-oleh dalam kehidupan manusia 
setelah bebas dari pandemi virus covid-19. Paradigma baru dalam pengembangan pendidikan seperti terus menggali informasi dengan bantuan digital untuk meningkatkan pengetahuan, keterampilan dan kharakter menjadi suatu keharusan. Metode belajar yang memadukan daring dan tatap muka menjadi kondisi yang sangat ideal di era pandemi Covid-19 dan kemajuan digital yang sangat cepat. Kondisi seperti inilah yang menjadi salah satu bukti bahwa manusia di muka bumi ini secara bertahap akan mengalami perubahan paradigma. Demikian halnya para guru di sekolah wajib harus berubah paradigmanya dalam menyelenggarakan program pendidikan secara khusus program merdeka belajar yang menjadi program prioritas Pemerintah untuk memajukan sumber daya manusia (SDM) Indonesia.

Sehubungan dengan adanya penurunan epidemi penderita covid-19, maka ada rencana pemerintah Indonesia di semester ganjil bulan Juli tahun ajaran 2021/2022 mencoba akan mulai memberlakukan proses belajar tatap muka di sekolah, meskipun sewaktu-waktu bisa berubah bila ditemukan lonjakan penderita Covid.Paradigma yang dibangun guru adalah bagaimana menciptakan proses belajar yang menarik dan menyenangkan ketika proses belajar dari dipadukan dengan tatap muka. Pendekatan proses belajar di sekolah yang memadukan daring dan tatap muka secara optimal harus diupayakan menjadi paradigma baru bagi anak didik dan para guru di sekolah, meskipun disadari bahwa ada keuntungan dan kelemahan dari sisi anak didik, memperoleh pengalaman belajar selama mengikuti proses belajar. Belajar secara tatap muka secara psikis akan sangat menguntungkan dibandingkan dengan daring. Sentuhan sosial dari guru ke murid dan dari murid ke murid memiliki nilai-nilai positip yang sangat kuat untuk 
membuat anak didik kuat dalam menghadapi berbagai problema hidup. Kualitas anak didik tidak hanya di ukur dari kemampuan menguasai pengetahuan, keterampilan tetapi memiliki kharakter yang tangguh dalam menghadi berbagai perubahan baik akibat kemajuan teknologi maupun segala perubahan yang terjadi dalam lingkungan sosialnya.

Kemajuan teknologi digital harus dapat dimanfaatkan secara optimal untuk melakukan perubahan atau loncatan yang berdampak pada peningkatan kualitas sumber daya manusia yang handal dan berkharakter Indonesia. Olehkarena itu, perubahan paradigma pada guru dan murid harus bersinergis dan mampu melakukan sesuatu yang berbeda kearah yang lebih baik.Keberhasilan mengembangkan pendidikanberdaya saing tinggidari Sabang sampai Merauke dan dari Miangas ke Pulau Rote menjadi citacita luhur seluruh rakyat Indonesia.

Pendidikan secara etimologi berasal dari bahasa Latin disebut Ducure yang artinya menuntun, mengarahkan, memimpin. Pendidikan dapat juga diartikan sebagai pondasi dalam membangun hidup yang berkualitas dan berdaya saing. Pendidikan dalam proses belajar mewujudkan tiga domain yaitu kognitif, psikomotor dan afektif. Pendidikan dalam proses belajar gerak diwujudkan dalam tiga tahapan yaitu kognitif, asosiatif dan otonom.Pendidikan dalam undang-undang sistem pendidikan nasional Nomor 20 tahun 2003 adalah usaha sadar dan terencana untuk mewujudkan suasana belajar dan proses pembelajaran agar peserta didik secara aktif mengembangkan potensi dirinya untuk memiliki kekuatan spiritual keagamaan, pengendalian diri, kepribadian, kecerdasan, akhlak mulia serta keterampilan yang diperlukan dirinya, masyarakat, bangsa dan negara. Berdasarkan uraian 
diatas, maka perubahan paradigma baru guru untuk menyesuaikan dengan kondisi riil sebagai akibat dari perkembangan revolusi industri 4.0 sangat diperlukan dalam pengembangan pendidikan di Indonesia menuju Indonesia emas 2045. 
12 | Akademisi dalam Lingkaran Daring 


\title{
“MIKIR” DI MASA PANDEMI COVID-19
}

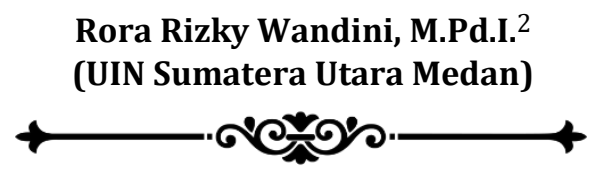

"MIKIR adalah singkatan dari mengalami (dalam proses melakukan ini siswa mengamati dan melakukan), interaksi, komunikasi dan refleksi. Pendekatan MIKIR ini adalah pendekatan yang dikenalkan oleh Tanoto Foundation pada tahun 2019 dalam kegiatan pelatihan guru-guru di beberapa kota besar di Indonesia."

\begin{abstract}
Covid-19 yang berlangsung di Indonesia sudah sekitar 1 tahunan lebih. Selama masa pandemi covid ini proses pembelajaran baik ditingkat sekolah dasar sampai diperguruan tinggi dilakukan dengan menggunakan pembelajaran jarak jauh (PJJ). Model pembelajaran yang ditawarkan oleh pemerintah yaitu berbasis online (daring). Banyak bantuan kuota yang diberikan pemerintah untuk mendukung kegiatan pembelajaran tersebut dapat berjalan dengan baik. Namun, apa daya kemampuan rakyat Indonesia terkait hal tersebut tidak sebanding dengan harapan yang diinginkan pemerintah. Selain bantuan kuota banyak pelatihan-pelatihan yang diberikan kepada pendidik khususnya guru sekolah dasar terkait bagaimana

2 Penulis adalah dosen di UIN Sumatera Utara Medan. Penulis bisa dikontak di email rorarizkiwandini@uinsu.ac.id
\end{abstract}


menjalankan pembelajaran jarak jauh ini. Namun karena fasilitas yang dimiliki siswa yang tidak merata, yang menjadi salah satu kendala dalam tercapainya tujuan pembelajaran. Adanya keterbatasan fasilitas siswa ini maka penulis menawarkan sebuah pendekatan yang masuk kedalam model pembelajaran aktif, yaitu MIKIR. MIKIR adalah singkatan dari mengalami (dalam proses melakukan ini siswa mengamati dan melakukan), interaksi, komunikasi dan refleksi. Pendekatan MIKIR ini adalah pendekatan yang dikenalkan oleh Tanoto Foundation pada tahun 2019 dalam kegiatan pelatihan guru-guru di beberapa kota besar di Indonesia yaitu di Medan, Jakarta, Jambi dll.

MIKIR yang merupakan singkatan dari kegiatan; 1. Mengalami yaitu kegiata siswa dalam proses pembelajaran harus terlibat aktif dengan mengoptimalkan fungsi indera yang dimiliki sehingga dapat memahami konsep yang lebih joss. Pada kegiatan mengalami ini siswa dapat melakukan dua kegiatan yaitu kegiatan mengamati dan kegiatan melakukan. Pada kegiatan mengamati merupakan kegiatan awal yang dilakukan pada proses pembelajaran dan fokus pada kegiatan mengamati ini terletak pada siswa. Dalam proses mengamati kegiatan pembelajaran lain yang dapat dilakukan siswa ada kegiatan bertanya, mengumpulkan informasi dan mengasosiasi. Kegiatan mengamati ini bertujuan untuk melatih siswa mencari informasi secara teliti dan bersungguh-sungguh. Dalam Permendikbud No 103 tahun 2014 proses mengamati dalam kegiatan pembelajaran berupa kegiatan yang diakumulasi oleh panca indera seperti kegiatan melihat, mendengar, dan menyimak dengan bantuan media atau tanpa media. Pada kegiatan mengamati ini akan membawa siswa untuk memperoleh keterampilan dalam mengidentifikasi kosep, fakta dan prosedural. Setelah siswa melakukan kegiatan mengamati lalu siswa 
melakukan. Kegiatan melakukan ini dapat diinterpretasikan dengan betanya jawab, mendemonstrasikan sesuatu, wawancara, melakukan percobaan atau meminta siswa melakukan dan membuat sesuatu sesuai materi yang diajarkan. Pada kegiatan melakukan ini siswa dilatih untuk memperoleh data-data yang telah didapat dari kegiatan mengamati; 2. Interaksi, interaksi merupakan kegiatan yang dilakukan dua orang atau lebih dalam memperoleh, mengulas, mengidentifikasi, menanggapi sebuah informasi dan gagasan. Kegiatan interaksi dalam prose pembelajaran dapat dilakukan antara guru dengan siswa, siswa dengan siswa, siswa dengan sumber belajar, guru dengan sumber belajar, siswa dengan guru dan sumber belajar. Dalam kegiatan interaksi ada beberapa yang harus diperhatikan oleh seorang guru yaitu kondisi psikologis siswa dan kondisi kelas. (Djamarah, 2010). Proses interaksi yang baik akan memberi manfaat pada siswa dalam mengembangkan kemampuan yang dimilikinya baik dalam kognitif, afektif maupun psikomotoriknya. ( Sanjaya, 2006); 3. Komunikasi, kegiatan komunikasi merupakan kegiatan menyampaikan informasi, ide maupun gagasan, dari sesorang kepada orang lain. Kegiatan komunikasi ini tidak terlepas dari kiegiatan interaksi. Pada kegiatan komunikasi dapat dilakukan dengan lisan maupun tulisan. Kegiatan komunikasi dengan lisan maupun tulisan ini dapat diinterpertasikan dengan kegiatan tanya jawab, menyampaikan hasil diskusi, menyapaikan laporan percobaan, menyampaikan hasil diskusi, menyampaikan hasil wawancara dll.; 4. Refleksi, kegiatan refleksi adalah kegiatan meriview kembali pengalaman belajar siswa, dengan cara menanyakan bagaimana perasaan siswa ketika dalam proses pembelajaran, apa yang diperoleh siswa ketika sudah melakukan kegiatan pembelajaran yang dilakukannya 
hari ini. Dengan kata lain pada kegiatan refleksi ini siswa tau apa manfaatnya ia mempelajari materi hari ini.Kegiatan pembelajaran dengan MIKIR ini guru dapat melakukannya secara terpisah tahapannya atau juga bisa dimunculkan sekaligus dalam satu kegiatan.

Adapun kelebihan dari pendekatan MIKIR yaitu : 1 . Siswa belajar aktif karena kegiatan pembelajaran berfokus kepada siswa 2. Siswa akan mudah dalam memahami materi, 3. Siswa dapat belajar mandiri tanpa kehadiran guru, 3. Orang tua tau cara bagaimana mendampingi anaknya belajar. Sedangkan kelemahan dalam penerapan pendekatan MIKIR ini yaitu 1. Guru harus lebih kreatif dalam memunculkan ide-ide pembelajaran. 2. Guru harus memiliki banyak referensi sumber belajar. Berikut adalah gambaran sknario pembelajaran menggunakan pendekatan MIKIR di masa pandemi covid 19.

\section{SKNARIO PEMBELAJARAN MENGGUNAKAN PENDEKATAN MIKIR DI MASA PANDEMI COVID}

\begin{tabular}{|c|c|c|}
\hline Kegiatan & \multicolumn{1}{|c|}{ Deskripsi } & $\begin{array}{c}\text { Alokasi } \\
\text { Waktu }\end{array}$ \\
\hline Pembukaan & $\begin{array}{l}\text { Persiapan sebelum pembelajaran on line } \\
\text { - Membuat WAG kelas II dan mengirimkannya } \\
\text { kepada WA grup orang tua dengan } \\
\text { memberitahukan bahwa ada group kelas II } \\
\text { untuk belajar bersama siswa. }\end{array}$ & \\
& $\begin{array}{l}\text { Kegiatan Awal } \\
\text { - Mengecek apakah semua siswa sudah masuk } \\
\text { ke WAG klas II sambil mengisi daftar hadir } \\
\text { kelas-jika diperlukan difoto dan ditampilkan } \\
\text { dilayar hp. } \\
\text { - Siswa diminta membuka vidio tentang } \\
\text { kontrak belajar (memulai dan mengakhir } \\
\text { pembelajaran, tugas belajar yang akan }\end{array}$ & \\
\hline
\end{tabular}




\begin{tabular}{|l|l|l|}
\hline dilakukan secara individu maupun kelompok, \\
serta penilaian danpembobotanya) \\
- Siswa diberi kesempatan untuk menanyakan \\
hal yang belum dipahami terkait dengan \\
kontrak belajar melalui chatsms \\
- Kemudian dilanjutkan dengan pembacaan \\
tujuan pembelajaran dan langkah belajar \\
yang akan dilalui siswa dalam pembelajaran \\
online
\end{tabular}




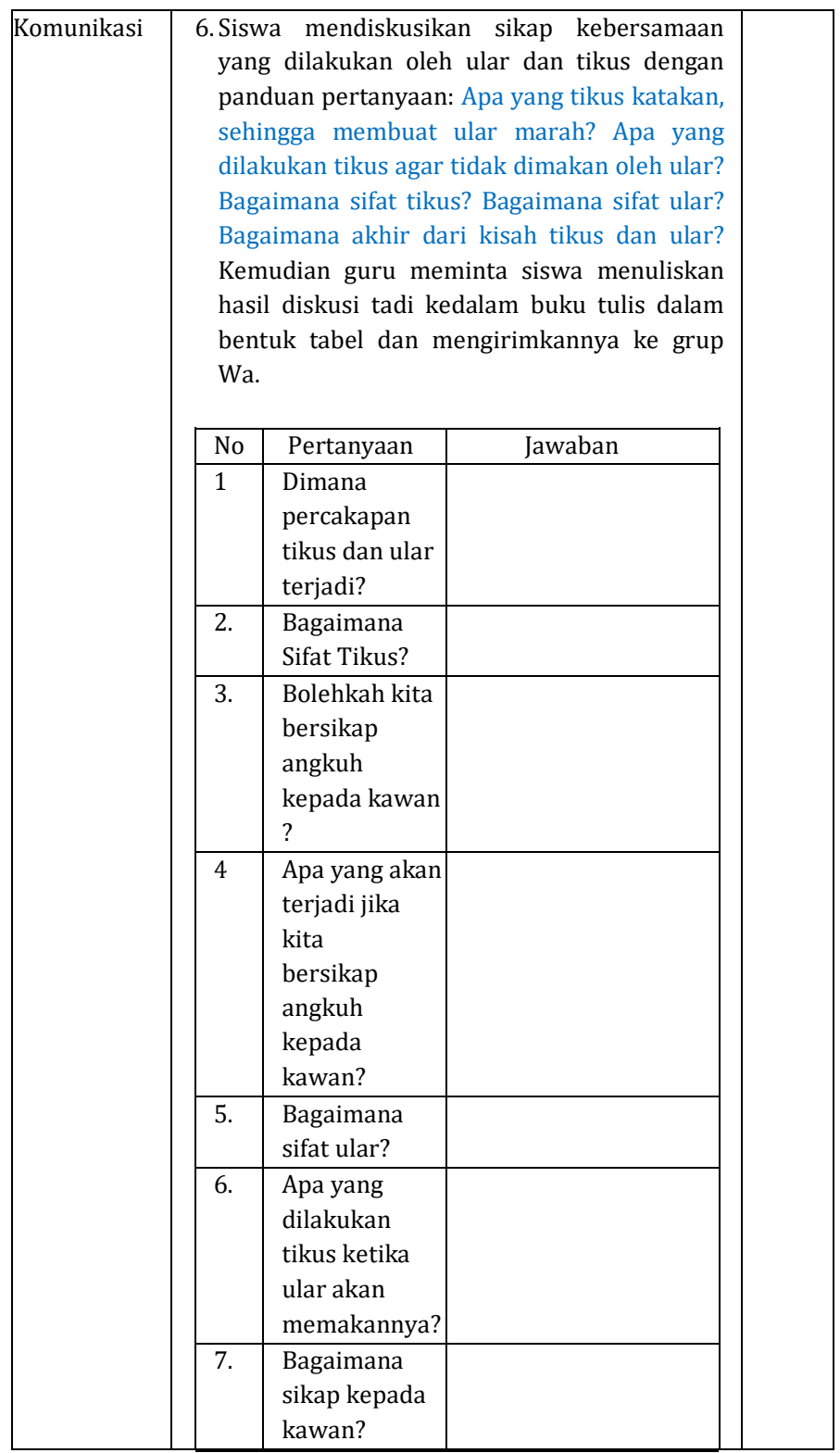

18 | Akademisi dalam Lingkaran Daring 


\begin{tabular}{|l|l|}
\hline Penutup & Siswa bersama guru melakukan refleksi dengan \\
\hline Refleksi & panduan pertanyaan : Apa saja yang telah \\
& dipelajari dari kegiatan hari ini?, Apa yang akan \\
dilakukan untuk menghargai perbedaan di & sekitar? Bagaimana perasaan setelah melakukan \\
pembelajaran hari ini. (siswa diminta & \\
& menuliskannya \\
dibuku tulis dan mengirinmkannya ke grup Wa)
\end{tabular}


20 | Akademisi dalam Lingkaran Daring 


\section{KEMANDIRIAN BELAJAR BAHASA INGGRIS MELALUI ARTIFICIAL INTELLIGENCE PADA MASA PANDEMI COVID-19}

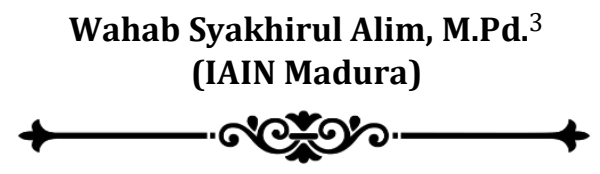

"Penggunaan beberapa aplikasi dari AI dalam bidang pembelajaran Bahasa Inggris sudah mulai berkembang.

Pendidik sudah tidak lagi disibukkan dengan beban administrasi serta pengkoreksian hasil kerja peserta didik. Namun AI tidak akan pernah mampu menggantikan posisi seorang pendidik dalam menanamkan nilai moral dan karakter kepada peserta didik dalam proses pembelajaran."

Dada masa pandemi yang dialami oleh seluruh lapisan masyarakat global mempercepat terjadinya era disrupsi teknologi, dimana terjadinya lompatan teknologi secara massif dari sistem lama ke sistem baru.

\footnotetext{
${ }^{3}$ Penulis adalah dosen IAIN Madura pada Prodi Tadris Bahasa Inggris. adapun buku yang pernah ditulis bersama adalah English For Islamic Studies, Adaptasi Kebiasaan Baru Masyarakat Indonesia Pada Era Pandemi Covid 19`: Tinjauan Berbagai Disiplin Ilmu, Pendidikan Karakter, Mudahnya Memahami Metode Penelitian. Penulis dapat dihubungi melalui email: wahab-alhabsy@iainmadura.ac.id. Sinta ID: 6745562. Orchid ID: 0000-0003-4286-1418 dan Google Scholar: SjOq4mQAAAAJ
} 
Perihal tersebut juga membuat perubahan yang sangat fundamental pada proses iklim pembelajaran yang semula menggunakan metode pengajaran tradisional, dimana tidak lagi mampu memenuhi kebutuhan masyarakat kontemporer,maka dengan cepat beralih pada pembelajaran online(Han, 2019). Model pembelajaran Bahasa Inggris selama ini tidak berjalan efektif dan hanya memberikan dampak kecil terhadap kualitas keterampilan Bahasa Inggris peserta didik karena ia dilaksanakan secara tradisional yang cakupannya dan kemampuan seorang pengajar terbatas dalam memeriksa ketepatan, dan keakuratan suatu keterampilan bahasa Inggris. Sehingga banyak kemampuan bahasa Inggris peserta didik yang jauh dari kata baik. Oleh karenanya perlu adanya perubahan yang mendasar dalam proses pembelajaran, yakni dengan mengintegrasikan teknologi komputer dan teknologi kecerdasan buatan sehingga mampu menarik minat belajar mahasiswa serta mampu mengurangi beban mengajar tenaga pendidik (Han, 2019). Hal tersebut merupakan win-win solution dari persoalan yang ada, dimana siswa akan sangat tertarik mengikuti proses pembelajaran dengan senang hati serta mampu meningkatkan kemampuan keterampilan Bahasa mereka dan juga seorang tenaga pendidik akan juga terbantukan dengan adanya teknologi computer dan teknologi kecerdasan buatan tersebut.

Di masa pandemi ini, seluruh stakeholder pendidikan sudah mulai memanfaatkan teknologi sebagai media pelestarian kegiatan belajar mengajar, selain karena ketaatan pada protocol kesehatan mereka juga mencoba banyak hal baru dengan menggunakan berbagai teknologi kecerdasan buatan. Benko \& Sik Lányi, (dalam Suryana, Asrianto, \& Murwantono, 2020) mengemukakan bahwa Artificial Intelligence (AI) diciptakan oleh John McCarthy dalam workshop 
Dartmouth College yang diadakan pada musim panas tahun 1956. AI merupakan salah satu cabang ilmu komputer yang menekankan pada penciptaan mesin cerdas yang bekerja dan bereaksi seperti manusia meliputi: pengenalan ucapan, pembelajaran, perencanaan, pemecahan masalah(Habeeb, 2017). Secara sederhana AI dapat diartikan sebagai proses simulasi kecerdasan manusia pada sebuah mesin yang telah diprogramkan melalui sistem computer.

\section{Dampak AI Pada Bidang Pendidikan}

Kehadiran AI diakui mampu memberikan banyak manfaat dalam berbagai bidang. AI tidak hanya mampu memudahkan kerja manusia, tetap juga mampu menyelesaikan pekerjaan yang banyak dan berulang dengan waktu yang ringkas. Berikut beberapa dampak positif dari hadirnya AI pada bidang pendidikan, yaitu:

1. Memudahkan dalam hal manajemen

2. Membantu pembelajaran yang lebih menarik, isi lebih smart, lebih disesuaika dengan situasi nyata

3. Mengelompokan dan mendeteksi siswa yang mengalami kesulitan dalammenangkap pelajaran di kelas, sehingga guru nantinya dapat membantu lebih tepat

4. Siswa/mahasiswa lebih senang dan bersemangat karena dibantu sesuai dengan kebutuhan, kelemahan, dan apa yang mereka belum tahu. Mereka juga dapat belajar dari apa yangmereka senangi. Dengan cara itu mereka dapat maju lebih cepat.

5. Model trial dan error bagi mereka juga tidak menakutkan karena dilakukan sendiri denganprogam, dan tidak dengan guru. 
6. Belajar menjadi lebih personal, dan siswa dapat lebih bervariasi untuk menemukan datadan mengolahnya.

7. Mereka lebih senang karena pada akhir selalu ada feedback dan langsung diperbaiki

8. Membantu menjadi tutor bagi siswa dan mahasiswa (Kusumadewi, 2003)

9. Mempermudah para guru dalam menggandakan dan menyebarluaskan data pembelajaran

10.Mampu dikerjakan dengan relative lebih cepat serta menyimpan data lebih banyak

11.Menggantikan tugas manusia yang berulang-ulang

Sedangkan berikut beberapa dampak negative dari AI, yakni:

1. Menghilangkan pekerjaan konvensional

2. Tidak memiliki common sense seperti halnya manusia

3. Memiliki resiko dibobol

Dengan memperhatikan dampak yang diberikan AI sangat besar terhadap dunia pendidikan, maka sangat besar potensi yang dimiliki peserta didik dan pendidik untuk berkembang dan mencapai batasan maksimal produktivitas, oleh karenanya dorongan kemandirian belajar sangat memainkan peran penting disini. Kesadaran akan segala kemudahan yang telah ada di depan mata maka akan menjadi mesin penggerak utama dalam mencapai keinginan yang diimpikan.

\section{AI Pada Pembelajaran Bahasa Inggris}

Pembelajaran Bahasa Inggris yang meliputi speaking, listening, writing, dan reading merupakan kemampuan dasar yang harus dimiliki seorang pembelajar Bahasa 
Inggris. Penggunaan beberapa aplikasi dari AI dalam bidang pembelajaran Bahasa Inggris sudah mulai semakin tumbuh dan berkembang, pendidik sudah tidak lagi disibukkan dengan beban administrasi serta pengkoreksian hasil kerja peserta didik. Demikian juga peserta didik, mereka terbantukan dengan hadirnya AI yang mampu memfasilitasi kebutuhan dasar mereka akan pengetahuan beserta kemudahannya.Penerapan AI pada pembelajaran Bahasa Inggris yang telah banyak dipergunakan adalah:

1. AI pada Pronunciation

Padapemberlajaran pronunciation terdapat beberapa aplikasi mobile AI yang dapat digunakan yakni LearnEnglish Sounds Right, Pronunciation App, ELSA Speak, Pronunroid - IPA Pronunciation, Say it: English Pronunciation, Forvo Pronunciation guide (Disri, 2020), Computer Assisted pronunciation instruction (Liu \& Hung, 2016) and spell checker (Noviyanti, 2020).

2. AI pada Writing:

Pembelajar dapat menggunakan AI pada writing berupa Writesonic, Wordsmith, AI Writer, QuillBot, Article Forge (Nicholas, 2021), Narrative Science, ScriptBook, Persado, Phrasee (Ankur, 2019), ProWritingAid. Gumawang Jati dalam materinya di seminar ELITE (2021) juga menyebutkan beberapa aplikasi pada pembelajaran writing, yakni Essaybot, Writing Revisor, Padlet, SAA Writing Reviser, paperrater. Namun demikian AI tidak akan memeriksa arti kata-kata yang kita berikan, bagaimana yang dimiliki bisa terstruktur atau tidak, dan seberapa baik argumen yang kita miliki bisa didukung. 


\section{AI pada Reading}

Berikut beberapa website dan aplikasi yang bisa digunakan, yaitu

http://www.teachthought.com/pedagogy/literacy/ 15-of-the-best-educational-apps-for-improvedreading-comprehension/, http://www.readingrockets.org/literacyapps, http://blog.ed.ted.com/2015/09/19/25-awesomeapps-for-teachers-recommended-by-teachers/, and https://www.popsugar.com/ tech/Best-ReadingApps-38193336(Jati, 2018), Readlang (reading text from website), Padlet (berbagi daftar kosa kata dan pemahaman teks bacaan), dan Quillionz (Guru membuat pertanyaan dari teks bacaan).

4. AI pada Listening

Beberapa alikasi mobile AI yang dapat digunakan adalah TuneIn - NFL Radio, Free Music, Sports \& Podcasts, Netflix, Joox Music, dan VOA Learning English Listening (Suryana et al., 2020).

Dengan adanya masa pandemi sekarang ini, maka seorang pelajar dan pendidik secara otomatis memiliki waktu yang banyak untuk secara mandiri mengembangkan potensi yang dimiliki melalui beberapa tawaran yang diberikan oleh AI.

\section{Posisi AI Pada Bidang Pembelajaran}

Pada hakekatnya AI memposisikan diri dalam membantu pekerjaan manusia menjadi lebih mudah dan efektif, serta meningkatkan pemikiran manusia guna meningkatkan proses pendidikan bukan untuk menguranginya menjadi serangkaian prosedur berupa isi penyampaian, control dan penilaian (Popenici \& Kerr, 2017). Dengan kata lain, AI tidak memiliki otoritas pengambilan keputusan dalam melaksanakan suatu 
proses pembelajaran masih dioperasikan oleh manusia oleh karena AI tidak memiliki common sense. AI juga tidak akan pernah mampu menggantikan posisi seorang pendidik dalam menanamkan nilai moral dan karakter kepada peserta didik dalam proses pembelajaran.

\section{DAFTAR PUSTAKA}

Ankur. (2019). Artificial Intelligence in Writing. Retrieved May 16, 2021, from https://www.unsupervisedlearningbook.com/the blog/2019/10/21/artificial-intelligence-inwriting

Disri, N. (2020). 6 Aplikasi Ini Bisa Ningkatin Kemampuan Pronunciation Kamu, Lho! Retrieved May 16, 2021, from https://teknologi.id/insight/6-aplikasi-ini-bisaningkatin-kemampuan-pronunciation-kamu-lho

Habeeb, A. (2017). Artificial Intelligence. Research Gate, $7(2)$.

https://doi.org/10.13140/RG.2.2.25350.88645/1

Han, B. (2019). Application of Artificial Intelligence in Autonomous English Learning Among College Students. International Journal of Emerging Technologies in Learning, 14(6), 63-74. https://doi.org/10.3991/ijet.v14i06.10157

Jati, G. (2018). The Use of Smartphone Applications in English Language Teaching and Learning. Jurnal Sosioteknologi, 17(1), 144-153.

Jati, G. (2021). Artificial Intelligence in ELT. Bandung. Retrieved from https://www.canva.com/design/DAET3xAWMfM /PMhkDPqkR0QmrguDbmCjKg/view\#1 
Kusumadewi, S. (2003). Sri Kusumadewi. 2003. Artificial Intelligence (Teknik dan Aplikasinya). Yogyakarta: Graha Ilmu.

Liu, S.-C., \& Hung, P.-Y. (2016). Teaching Pronunciation with Computer Assisted Pronunciation Instruction in a Technological University. Universal Journal of Educational Research, 4(9), 1939-1943. https://doi.org/10.13189/ujer.2016.040902

Nicholas, G. (2021). 5 AI Tools that Can Think and Write Like Humans. Retrieved May 16, 2021, from https://www.zdnet.com/article/5-ai-tools-thatcan-think-and-write-like-humans/

Noviyanti, S. D. (2020). Artificial Intelligence (AI)-Based Pronunciation Checker: An Alternative for Independent Learning in Pandemic Situation. ELT Echo: The Journal of English Language Teaching in Foreign Language Context, 5(2), 162. https://doi.org/10.24235/eltecho.v5i2.7246

Popenici, S. A. D., \& Kerr, S. (2017). Exploring The Impact of Artificial Intelligence on Teaching and Learning in Higher Education. Research and Practice in Technology Enhanced Learning, Vol. 12. https://doi.org/10.1186/s41039-017-0062-8

Suryana, I., Asrianto, \& Murwantono, D. (2020). Artificial Intelligence To Master English Listening Skills for Non-English Major Students. Journal of Languages and Language Teaching, 8(1), 48. https://doi.org/10.33394/jollt.v8i1.2221 


\section{STRATEGI GURU DALAM MEMANFAATKAN PEMBELAJARAN BERBASIS DIGITAL PADA KURIKULUM DARURAT}

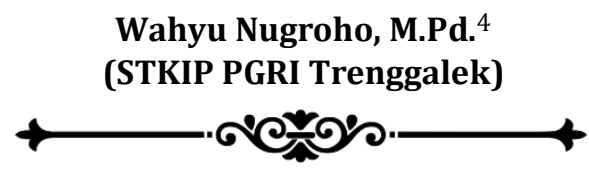

"Pembalajaran dengan menggunakan digitalisasi dapat diartikan sebagai proses melek teknologi yang mendorong dalam pembelajaran yang lebih aktif, inovatif dan interaktif agar peserta didik mampu mengkonstruk pengetahuan dan pengembangan diri, oleh sebab itu guru wajib membuat gagasan nyata di lapangan dalam bentuk strategi pembelajaran yang tepat sasaran."

\section{A. Pendahuluan}

Genomena perkembangan dunia era digital memberikan banyak pengaruh terhadap berbagai kehidupan yang cukup signifikan. Banyak perubahan yang di alami masyarakat terlebih profesi seorang guru

4 Penulis lahir di Kabupaten Trenggalek, 26 April 1992, penulis merupakan Dosen STKIP PGRI Trenggalek dalam bidang Pendidikan Guru Sekolah Dasar. Penulis menyelesaikan gelar Sarjana Guru Sekolah dasar di Universitas Kanjuruhan Malang (2016), sedangkan gelar Magister Pendidikan diselesaikan di Universitas Negeri Malang (2019). Email: nugrohowahyu.wn93@gmail.com 
dalam mengembangkan pembelajaran. Terlebih pada saat fenomena corona virus disease pada tahun 2019 sampai saat ini, memaksa guru harus mengikuti perkembangan teknologi dan informasi yang sering digunakan khususnya dalam pembelajaran berbasis digital untuk menentukan strategi yang efektif agar pendidikan tetap berjalan di tengah keterbatasan skala nasional.

Keterbatasan ruang lingkup pelaksanaan di dunia pendidikan yang muncul akibat penyebaran corona virus disease mendorong pemerintah untuk mengeluarkan kebijakan kurikulum pada kondisi khusus (darurat). Melalui permendikbud nomor 719/P/2020 tentang pedoman pelaksanaan kurikulum pada satuan pendidikan dalam kondisi khusus, menjadi salah satu produk kebijakan pemerintah dalam melaksanakan kurikulum di satuan pendidikan untuk memberikan fleksibilitas pelaksanaan kurikulum yang sesuai dengan kondisi di wilayah satuan pendidikan masing-masing. Ada tiga opsi pilihan yang di tawarkan pemerintah agar tetap melangsungkan kegiatan pelaksanaan pembelajaran, yakni 1) tetap mengacu pada kurikulum nasional, 2)menggunakan kurikulum darurat, 3) melakukan penyederhanaan kurikulum secara mandiri( Mendikbud, 2020).

Fleksibilitas pelaksanaan kurikulum dalam kondisi khusus perlu di laksanakan dengan strategi khusus agar ketercapaian tujuan pembelajaran tetap terpenuhi sesuai harapan, salah satunya dengan meningkatkan sumber daya manusia khususnya guru sebagai ujung tombak dalam memberikan pengalaman, dan pengetahuan kepada siswa walaupun di tengah pandemi, salah satu langkah yang perlu dilakukan guru adalah dengan pemanfaatan pembelajaran berbasis Digital. Pemanfaatan pembalajaran dengan 
menggunakan digitalisasi dapat diartikan sebagai proses melek teknologi yang mendorong dalam pembelajaran yang lebih aktif, inovatif dan interaktif agar peserta didik mampu mengkonstruk pengetahuan dan pengembangan diri, oleh sebab itu guru wajib membuat gagasan nyata di lapangan dalam bentuk strategi pembelajaran yang tepat sasaran. Pembelajaran dapat dikatakan efektif apabila pembelajaran yang telah di lakukan mampu menjawab kebutuhan siswa dan perkembangan jaman, tentu agar strategi yang di susun oleh guru tepat, maka perlu adanya peningkatan literasi digital.

\section{B. Strategi Guru dalam pemanfaatan ICT pada Kurikulum Darurat}

Terdapat salah satu cara yang dapat dilakukan guru dalam pemanfaatan Information and Communication Technology (ICT) saat pra dan pasca pembelajaran pada kurikulum kondisi khusus. Namun sebelum membahas terkait strategi yang dapat dilakukan, seorang guru harus tahu bahwa dalam menyusun suatu kegiatan atau strategi dalam pembelajaran ada tiga poin, yakni: 1) bagaimana seseorang belajar, 2) apa yang akan di pelajari, dan 3) kapan dan dimana pembelajaran akan berlangsung (Resnick, 2011). Tiga pertanyaan tersebut wajib di telaah guru sebagai bahan penguat strategi yang akan di gunakan dalam melaksanakan pembelajaran. Setelah merumuskan bagaimana siswa belajar guru juga perlu menyiapkan materi apa yang akan di belajarkan, selanjutnya tinggal kapan dan dimana sarana atau tempat yang digunakan sebagai keberlangsungan proses pembelajaran.

Setidaknya terdapat dua strategi yang dapat diterapkan oleh guru dalam pemanfaatan pembelajaran berbasis digital, yaitu: 


\section{Menyusun platform dengan menggunakan aplikasi sendiri}

Dalam menyusun dan menciptakan aplikasi sendiri yang nantinya akan di gunakan dalam proses pembelajaran memang tidak mudah, dan melalui proses yang cukup rumit bagi sebagian besar kalangan guru, namun tidak menutup kemungkinan guru dapat mengembangkan dan membuat aplikasi sederhana yang akan digunakan dalam menunjang pembelajaran, terlebih jika guru tersebut memiliki pemahaman, kemampuan dan kualitas yang baik dalam memanfaatkan teknologi, adapun langkah secara umum adalah dengan penguasaan dalam merancang aplikasi berbasis data, kemudian merancang aplikasi pembelajaran sesuai platform yang akan digunakan seperti aplikasi berbasis web, learning tool, multimedia, dan tutorial. Pada aplikasi berbasis web guru dapat menggunakan platform yang sudah di sediakan seperti blogg, wordpress, serta pemanfaatan konten kreator bagi guru untuk mengembangkan potensi diri melalui channel youtube pribadi.

\section{Menggunakan platform aplikasi yang sudah tersedia}

Penggunaan aplikasi yang sudah tersedia platformnya perlu di maksimalkan guru dalam mengembangkan potensi siswa dalam pembelajaran. Selain tingkat kesukaran yang relatif mudah, stategi dengan menggunakan aplikasi yang sudah siap pakai akan mempermudah guru untuk memanfaatkanya. Adapun aplikasi yang digunakan dalam learning managemen system (LMS) secara open source sebagai berikut.

a. Google Classroom

Pembelajaran dengan menggunakan LMS jenis ini lebih banyak digunakan oleh guru dalam 
mengaplikasikan strategi pembelajaran yang sudah di susun. Perusahaan ternama Google yang menjadi penyedia desain sistem pembelajaran ini dan dapat di akses secara gratis. Dengan menggunakan akun G-mail, seorang guru dapat mendaftarkan akunnya dalam sistem google classroom, banyak kemudahan dan fitur yang cukup mudah digunakan pendidik, seperti tersediannya kelas khusus yang bisa di olah dan di kembangkan berdasarkan fitur kalender, kemudian pengiriman tugas untuk setiap peserta didik sesuai kelas yang telah di tautkan, pemberian pertanyaan sebagai forum diskusi, pengecekan daftar hadir, serta kemudahan berbagi file dalam Drive, maupun link video pembelajaran.

b. Moodle

Pada aplikasi web ini sering di gunakan di seluruh dunia pendidikan karena lebih popular. Kelebihan aplikasi web bisa di akses lebih dari seribu materi untuk pembelajaran, selain itu aplikasi berbasis web ini juga memiliki fitur pelindung keamanan data pengguna. Kelebihan lain yang ada pada Moodle adalah tersedianya modul chat bot dengan tampilan seperti halnya jurnal, modul kuis, modul survei, polling, dan workshop.

c. PowerSchool (Schoology)

Provider ini memiliki yang hampir mayoritas oleh pengguna di Amerika Utara. Tampilan desain LMS ini lebih menarik perhatian para penggunanya secara visual, terlebih memiliki tampil seperti sebuah buku penilaian secara online, pencatat penggunaan fitur oleh peserta didik, daftar hadir yang interaktif, LMS ini cocok di gunakan siswa untuk pembelajaran jarak jauh selama pandemi. 


\section{d. Kahoot}

Fitur pada LMS Kahoot lebih banyak di manfaatkan untuk melakukan pembelajaran yang tidak hanya terfokus pada ranah kognitif namun juga motorik, seperti melaksanakan prettest-posttest, latihan soal, remidial, penguatan materi, serta pengayaan. Ranah motorik bisa di implementasikan dalam bentuk permainan yang memuat pertanyaan yang di sesuaikan dengan tingkat kesulitan dan waktu dari masing-masing pertanyaan dengan jawaban yang diwakili dalam bentuk gambar dan warna, sehingga siswa tidak merasa terbebani dalam belajar.

e. Edmodo

Edmodo membantu guru dalam memberikan tugas atau memberikan infromasi dalam berita grup dalam bentuk online. Fitur pengiriman tugas juga disediakan dalam aplikasi web Edmodo, sehingga siswa ataupun mahasiswa dapat mengirim tugas sesuai dengan petunjuk dari guru, selain itu siswa juga bisa berdiskusi di dalam forum untuk membahas topik materi yang telah di tentukan.

f. Quizizz

Aplikasi web ini cenderung ringan dalam penggunaannya, selain mudah di gunakan Quizizz memberikan kemudahan dan berguna untuk pemberian tugas atau pelaksanaan ujian tes. Guru bisa membentuk kelas secara online untuk membedakan kelas yang di ampunya, selain itu progres pembelajaran dapat di pantau secara bertahap. LMS ini sering di gunakan guru untuk memberikan butir soal baik dalam bentuk pilihan ganda maupun soal essay. Fitur dalam Quizizz memudahkan proses evaluasi soal karena jika 
siswa salah memjawab soal maka jawaban yang benar bisa di tampilkan beserta penjelasannya, hal ini hampir mirip dengan google form. Jika siswa telah selesai mengerjakan soal, maka pada akhir kuis akan di tampilkan tinjauan pertanyaan (review).

Selain LMS yang dapat di gunakan guru dalam mengaplikasikan strategi dalam pemanfaatan pembelajaran perlu adanya aplikasi pendukung sebagai sarana tatap muka secara maya, adapun aplikasi online yang dapat digunakan guru untuk Video Conference sebagai berikut: 1) Google Meet, 2) Zoom Meeting, 3) Microsoft Teams, 4) Facetime, 5) Whatsapp, 6) Cisco Webex, 7) Free Conference Call

Kegiatan pelatihan dalam meningkatkan pemanfaatan digital pembelajaran guru meliputi, pemberian materi terkait strategi mengajar, memberikan petunjuk fokus dalam proses perencanaan pembelajaran, memetakan faktor apa saja yang dapat mempengaruhi keberhasilan pelaksanaan pembelajaran, melakukan proses diskusi tanya jawab terkait kendala atau permasalahan yang ditemukan selama penyusunan startegi, kemudian yang terakhir perencanaan solusi yang tepat berdasarkan kajian (Purnasari, Sadewo 2020).

Semua bentuk LMS dan Fitur pendukung untuk Video Conference merupakan bagian perangkat dalam memaksimalkan strategi guru dalam memanfaatkan pembelajaran berbasis digital. Tidak ada yang lebih baik antara LMS yang satu dengan yang lainnya, sebab semua LMS tersebut hanya digunakan berdasarkan kebutuhan dan strategi yang diperlukan guru. Untuk memaksimalkan setiap LMS yang akan di kaji guru perlu melakukan pendalaman dan analisis kebutuhan terlebih dahulu. 


\section{DAFTAR PUSTAKA}

Halliday \& Resnick. 2011. Fundamentalis of Physics. Cleveland State University

Hidayat, Nandang., Khotimah, Husnul. 2029.

Pemanfaatan Teknologi Digital dalam Kegiatan PembelajaranJurnal unpak: Jurnal Pendidikan dan Pengajaran Sekolah dasar : . 2(1):10-15 (2019)

Kemendikbud. 2020. Pedoman Penyesuaian kebijakan pembelajaran di masa pandemi Covid-19.

Purnasari, Pebria., Sadewo, Yosua. (2020). Pemanfaatan Teknologi dalam Pembelajaran Sebagai Upaya Peningkatan Kompetensi Pedagogik. Jurnal Publikasi Pendidikan.Okt 20 vol.10 No.3

Sri Gusty, dkk. 2020. Belajar Mandiri: Pembelajaran Daring di Tengah Pandemi Covid-19. Yayasan Kita Menulis. 


\title{
PEMULIHAN UMKM PASCA PANDEMI DENGAN AKSELERASI DIGITALISASI
}

\author{
Lorena Dara Putri Karsono, M.M ${ }^{5}$ \\ (IAIN Kudus)

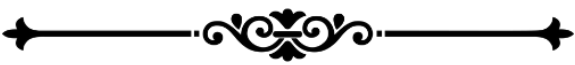

"Inilah momentum paling pas untuk mengasah kemampuan kita dalam hal entrepreneurial marketing. Digitalisasi akan terus mendorong banyak perusahaan, khususnya pelaku bisnis seperti UMKM (Usaha Mikro Kecil Menengah) untuk terus bertransformasi di masa mendatang"

Seperti yang telah kita rasakan bersama, pandemi Covid-19 dalam setahun belakangan ini telah mengubah secara signifikan kehidupan kita sehari-hari dalam berbagai aspek, baik secara individual maupun sosial. Banyak sekali penyesuain yang harus dilakukan, misalnya para profesional harus melakukan work-fromhome, kebiasaan sosial baru social distancing, sampai dengan penyesuaian strategi perusahaan agar bisa tetap bertahan dalam kondisi yang serba sulit ini. Penghujung tahun 2020 sudah terlewati dan sampai tulisan ini

${ }^{5}$ Penulis lahir di Karanganyar, 04 Oktober 1991, penulis merupakan Dosen IAIN Kudus dalam bidang ilmu Manajemen, penulis menyelesaikan gelar Sarjana Pendidikan Matematika di Universitas Sebelas Maret (2013), sedangkan gelar Magister Manajemen diselesaikan di Universitas Muhammadiyah Surakarta Program Studi Manajemen (2015). 
disusun, masih belum ada kepastian bagaimana menyudahi pandemi terbesar selama beberapa dekade ini. Ibarat menerjang kabut, kita tidak dapat melihat dengan jelas apa yang ada di depan kita. Tahun 2021 ini menjadi moment of truth pertama yang menjadi penentu apakah kita dapat benar-benar memiliki pencapaian tinggi di tahun 2030 apalagi di tahun emas 2045. Tahun yang akan datang tersebut menjadi momentum unik yang harus dimanfaatkan untuk memperkuat fondasi bisnis yang akan datang.

Sebab itu di tahun 2021, kita dituntut untuk memiliki strategic-flexibility. Artinya kita harus bisa mengidentifikasikan perubahan pada lingkungan eksternal, mengenali, dan mengambil langkah yang paling tepat dalam meresponnya. Kita harus memiliki sikap entrepreneurial marketing. Sehingga kita terlatih untuk lebih peka dalam mengambil peluang, menerima resiko yang terkalkulasi, dan berkolaborasi dengan pihak lain. Strategic flexibility harus kita ibaratkan seperti bermain catur, di mana ada rumus-rumus pembuka langkah catur yang sudah pakem. Di tengah permainan, kita harus menyesuaikan diri dengan situasi. Langkah per langkah kita tidak hanya merespons tetapi juga membuat rencana panjang mengenai kemungkinan yang akan terjadi. Hal yang sama pun berlaku untuk strategic flexibility. Kita diharuskan bisa menyesuaikan pada peraturan, etika dan moralitas. Tidak hanya merespons, kita perlu memikirkan langkah-langkah ke depan secara strategis. Sehingga ketepatan menganalisa situasi dan mengambil tindakan yang cermat menjadi kunci di sini.

Inilah momentum paling pas untuk mengasah kemampuan kita dalam hal entrepreneurial marketing. Tidak hanya bekerja secara profesional, namun juga berani mengambil resiko di masa yang sulit. Ada lima 
komponen yang perlu diperhatikan dalam mengambil resiko tersebut, yaitu digital, human, local, global, dan balance. Untuk kesempatan ini, akan kita kupas dalam hal digital. Digitalisasi akan terus mendorong banyak perusahaan, khususnya pelaku bisnis seperti UMKM (Usaha Mikro Kecil Menengah) untuk terus bertransformasi di masa mendatang. Walaupun pandemi sudah terlewati di suatu saat nanti. Kondisi makro ekonomi yang sebagian telah dituliskan sebelumnya, tentunya berdampak pada ranah mikro ekonomi, termasuk juga fungsi pemasaran yang dijalankan oleh perusahaan. Sebenernya sejumlah shifting di dalam pemasaran sudah nampak fenomenanya, namun tidak banyak yang menduga bahwa semua itu akan terealisasi secepat ini.

Salah satu fenomena yang sering ditemui adalah akselerasi digitalisasi. UMKM dipaksa go-digital agar dapat bertahan di kondisi sekarang. Segala aspek, tidak hanya bisnis, seperti dunia pendidikan, interaksi sosial bahkan pemerintahan menjadi sangat tergantung pada teknologi. Untuk itu di era 2021 ini sebagai new normal, new marketing, peran pemasaran digital akan semakin menguat. Hal ini menjadi kabar baik bagi para pelaku bisnis karena memang konektivitas masyarakat Indonesia melalui berbagai platform media sosial memang sudah cukup kuat. Oleh karena itu peran media sosial akan menjadi semakin penting dalam menciptakan awareness masyarakat terhadap suatu merek dan produk. Bahkan tak sampai disitu, media sosial pun menciptakan appeal dan menjadi sarana untuk mencari berbagai informasi. Teknologi daring pun akan berperan dalam melakukan transaksi pembelian.

Teknologi digital menjadi sangat diperhatikan para pelaku UMKM. Content marketing juga akan disoroti 
karena peran besarnya dalam hal memperkuat kehadiran merek sekaligus membentuk reputasi yang menjadikan langkah awal pembentukan kepercayaan masyarakat terhadap suatu merek. Kemampuan penguasaan perangkat digital dan internet ini merupakan hal mutlak yang harus dikuasai oleh UMKM jika ingin bertahan dalam persaingan (Purwana, Rahmi, \& Aditya, 2017). Tim pemasaran di berbagai perusahaan harus serius dalam mempersiapkan konten yang sifatnya edukatif, menghibur, meyakinkan, dan menginspirasi. Storytelling, termasuk melalui video marketing, menjadi semakin relevan. Akses untuk konten di beberapa platform, seperti Facebook, Instagram, Youtube, dan lain sebagainya juga harus jelas tujuannya apa, untuk siapa, kapan saatnya, dan seperti apa intensitasnya. Selain itu, konsistensi dan komunikatif diperlukan dalam membuat konten. Hal ini sangat penting untuk menciptakan engagement yang kuat dan menghasilkan retensi pelanggan sebagaimana diharapkan dan menjadi dasar dalam pembentukan loyalitas.

Berbagai perusahaan yang masih menggunakan offline, diharapkan dapat menerima kehadiran online marketing. Namun, sebagai catatan bahwa kehadiran secara bersamaan antara luring dan daring haruslah benar-benar terintegrasi dan konsisten. Pendekatan menggunakan daring marketing akan memberikan efisiensi pada perusahaan karena merupakan bagian dari konsep pemasaran direct-to-customer (D2C) yang merupakan tren populer di tahun 2021 ini. Penelitian Delloitte Economics (2015) menyatakan bahwa konsumen semakin terbiasa mengambil keputusan berdasarkan konten digital dan melakukan online dalam pembelian barang. Dengan demikian, pemulihan UMKM pasca pandemi dengan akselerasi digitalisasi 
merupakan langkah tepat untuk menjaga UMKM agar tetap sustainable dan meningkatkan volume penjualan.

\section{DAFTAR PUSTKA}

Delloitte Access Economics. 2015. UKM Pemicu Kemajuan Indonesia Instrumen Pertumbuhan Nusantara.

Purwana, D., Rahmi, \& Aditya, S. 2017. Pemanfaatan

Digital Marketing Bagi Usaha Mikro, Kecil, Dan Menengah (UMKM) Di Kelurahan Malaka Sari, Duren Sawit. Jurnal Pemberdayaan Masyarakat Madani (JPPM) 1(1): $1-17$

Slamet, R., Nainggolan, B., Roessobiyatno, Ramdani, H., Hendriyanto, A., \& Lu'ul, I. L. 2016. Strategi Pengembangan UKM Digital Dalam Menghadapi Era Pasar Bebas. Jurnalmanajemen Indonesia 16(2): $136-147$

Sunarsi, D., Wijoyo, H., Prasada, D., \& Andi, D. (2020, September). Pengaruh Lingkungan Kerja Terhadap Kinerja Karyawan Pada Pt. Mentari Persada Di Jakarta. In Seminar Nasional Manajemen, Ekonomi, Akuntansi (Vol. 5, No. 1, Pp. 117-123).

Wijoyo, H., Handoko, A. L., Santamoko, R. \& Sunarsi, D. (2020). Strategy Model for Character Education through Digital Media for Courses And Training Participants E- Prosiding Pascasarjana Universitas Negeri Gorontalo, 1-8.

https://www.marketeers.com/category/digital/

Diakses tanggal 8 Mei 2021 
42 | Akademisi dalam Lingkaran Daring 


\title{
MELAWAM PANDEMI DENGAN SCREEN RECORDER TOOL UNTUK MEMBUAT VIDEO PEMBELAJARAN
}

\author{
Dr. Nur Faizin, MA.; Dr. M. Wahid Dariyadi, M.Pd.I, \\ Muhammad Lukman Arifianto, SS., MA. ${ }^{6}$ \\ (Universitas Negeri Malang)

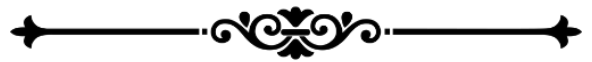

"Salah satu hikmah pandemi Covid-19 di masa perkembangan teknologi ini adalah terbukanya hati dan pikiran para guru sebagai manusia pendidik tentang betapa pentingnya mengembangkan diri"

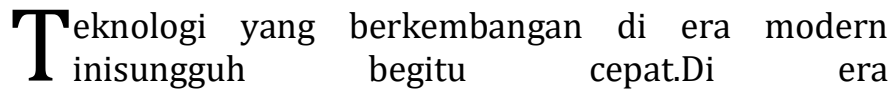
ini,teknologidirasakan telah memberikan berbagai faedah untuk kemajuan di dalam banyak lini kehidupan manusia. Perkembanganteknologi itubukanlagi dalamangka pertahun, perbulan, atauperhari, melainkandapat dikatakan perjam, bahkan permenit khususnya yang ada kaitannya dengan iptekom (ilmu pengethauan, teknologi informasi dan komunikasi). Inilah era manusia berkembang melalui teknologi

\footnotetext{
${ }^{6}$ Tiga orang ini adalah dosen di Universitas Negeri Malang atau yang lebih dikenal belakangan ini dengan nama Kampus UM. Kami mengucapkan terima kasih yang sebesar-besarnya kepada Fakultas Satra Jurusan Sastra Arab yang telah memberikan dukungan dalam pelaksanaan pengabdian kepada masyarakat tahun 2021 ini.
} 
elektronika dan digital. Manusia sekarang tidak dapat lepas dari penggunaan iptekom untuk agar dapat menyelesaikan tugas dan pekerjaan yang merupakan keharusan dan kewajibannya dalam kehidupan, akan tetapi yang harus disadari adalah cepatnya perkembangan iptekom itu harus didukung oleh Sumber Daya Manusia (SDM) yang juga berkembang sehingga manusia pun dapat segera mengikuti perkembangan iptekom tersebut, lebih-lebih di tahuntahun pandemi Covid-19 sekarang ini.

\section{Guru, Orangtua, dan Teknologi}

Para guru di daerah-daerah yang jauh dari pusat kota adalah SDM yang paling sulit mengikuti cepatnya laju perkembangan iptekom di atas. Para guru, terutama guru yang daerah pinggiran, banyak sekali yang menghadapi kesulitan dalam mendapatkan akses online. Bantuan paket data kepada guru dan wali murid pun sering tidak sampai pada waktu yang diharapkan sehingga mereka harus menggunakan media pembelajaran online yang paling memungkinkan, yaitu WA. Para orangtua wali juga sering menjadi guru dadakan, mereka harus menjadi guru di rumah masingmasing dan mengerjakan tugas-tugas yang diberikan para guru anak-anaknya melalui online WA. Yang cukup memprihatinkan adalah ternyata hampir semua guru itu hanya memberikan tugas dan tugas. Mereka jarang sekali memberikan penjelasan kepada peserta didiknya dalam pembelajaran online itu dan tidak lain alasannya adalah para guru itu belum mengerti cara menjelaskan secara online melalui video yang menarik dan interaktif.

Pada era pandemi Covid-19 ini terjadi banyak perubahan dalam kehidupan. Hingga saat ini, masyarakat Indonesia khususnya para guru harus melakukan pembelajaran secara daring. Mereka sangat membutuhkan teknologi sebagaimedia dalam 
pembelajaran secara daring. Hal ini tidak lain adalah agar proses pembelajaran terus bisa berjalan secara lebih baik dari sebelumnya yang hanya dalam bentuk tugas, kerjakan, dan kirimkan.

\section{Media Pembelajaran}

Media pada umumnya dipahami sebagai sesuatu yang mampu menyampaikan informasi antara sumber informasi dan penerima informasi. Dengan kata lain, media merupakan bentuk-bentuk dan saluran-saluran yang dipergunakan dalam menyampaikan informasi atau pesan (Arsyad, 2011: 8). Dalam Kamus bahasa Indonesia, medium artinya adalah "antara atau interval". Media adalah sarana untuk mengekspresikan pesan dan informasi. Menurut Heinich, et al (1982:17-18) media adalah mediator yang menyambungkan informasi antara pengirim dan penerima.Pada umumnya, media pembelajaran berarti semua alat yang dapat digunakan oleh guru untuk menyampaikan materi ajar kepada siswa dalam proses belajar mengajar untuk mencapai tujuan pembelajaran tertentu.Dalam proses belajar mengajar, media diperlukan agar proses pembelajaran dapat berjalan secara efektif dan menarik.

Media pembelajaran dapat digunakan dalam skala besar misalnya media yang berupa radio dan televisi atau dalam kelompok kecil seperti film, slide, video, atau individu seperti modul, komputer, perekam video. Penelitian menunjukkan bahwa media visual membuat pembelajan lebih dapat diterima oleh siswa daripada sekadar media teks dan lebih membantu dalam mengingat kembali nanti. Pertanyaan sederhana yang muncul, "mengapa siswa dapat mengingat apa yang ada di televisi dan melupakan apa yang di buku pelajaran mereka? Jawabnnya adalah karena media visual berperan membantu siswa mempertahankan ide secara kognitif. Bransford, Browning, dan Cocking juga 
mencatat peran penting dari teknologi untuk menciptakan lingkungan belajar dalam bentuk media komunikasi, seperti film, dokumenter, acara televisi yang memberikan pembelajaran secara interaktif dan dalam bentuk visualisasi.

Pembelajaran dengan media pembelajaran yang multimedia memang memiliki beberapa segi kekurangan dibandingkan secara bertatap muka langsung: perhatian dan motivasi semakin berkurang, artinya perhatian dan motivasi antara guru dan siswa serta semangat siswa dalam belajar lebih rendah dibandingkan dengan belajar yang dilakukan secara luring (tatap muka); seorang peserta didik dapat merasa kurang diperhatikan dan akhirnya menjadi malas sehingga dia akan cenderung bersifat pasif serta merasa tidak ingin mengikuti pelajaran materi yang sedang disampaikan; perbedaan individu guru yang lebih pasif dan tidak bisa memberikan kesan menyenangkan ketika di dalam pembelajaran.

\section{Sofware Perekam Video}

Untuk membuat video pembelajaran dapat digunakan beberapa software yang gratis maupun berbayar. Di antara software itu adalah Camtasia Studio. Software ini adalah program aplikasi yang diciptakan untukrecording, editing, dan publishingketika memproduk video tutorial dan presentasi yang tampak di layar (screen) computer atau laptop. Melalui manfaat Software Camtasia Studiokita dapat membuatsuatu video tutorialdengan tanpa camera video tambahan sebagaitambahan alatuntuk merekam (recording). Softwareini berfungsi multi, yaitu berfungsi menjadi softwareuntuk merekamdan sekaligus sebagai program editinguntuk membuat video tutorial. 


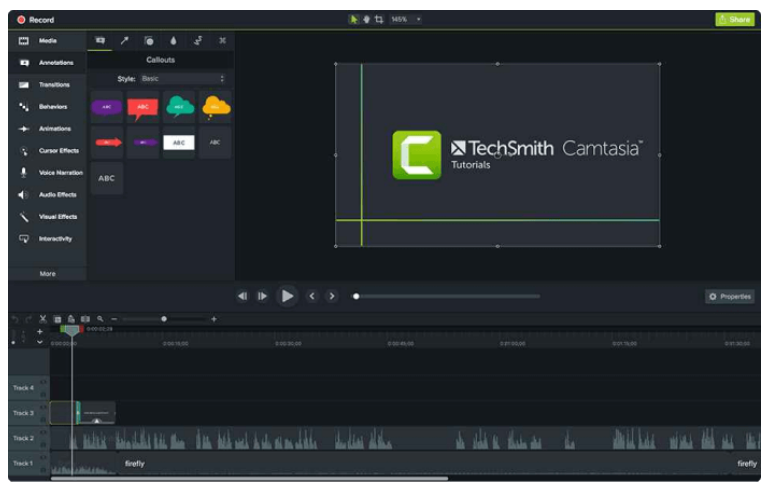

Gambar 1: aplikasi Camtasia

CamStudio, sebuah software pilihan yang cukup baik untuk perekaman dengan kebutuhan pengeditan minimal. Software ini cukup ringan digunakan khususnya dalam membuat video dalam format avi yang nantinya dapat dikonversi ke swf. Kelebihan software menarik bagi sejumlah orang meskipun masih memerlukan pengembangan lebih lanjut dan peningkatan dukungan teknis yang lain.

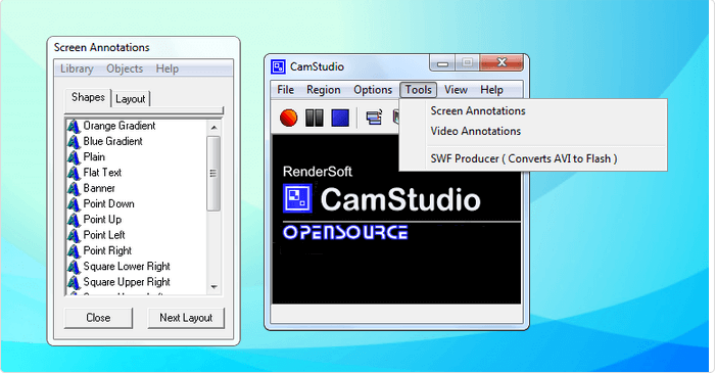

Gambar 2: aplikasi CamStudio

Screencast-O-matic yaitu alat pembuat video yang mudah untuk membantu agar lebih fokus pada hal yang penting. Digunakan untuk membuat tutorial atau pelajaran untuk instruksi kelas. Software ini 
memungkinkan pendidik untuk menggunakannya seperti waktu di dalam kelas dengan lebih efisien. Dengan alay ini guru dapat membangun hubungan dua arah (guru dan murid) secara otentik dengan siswa. Video bimbingan dapat dipersonalisasi dengan mudah dan membantu agar siswa memahami materi yang diajarkan dengan lebih muda dan berfikir secara kolaboratif.

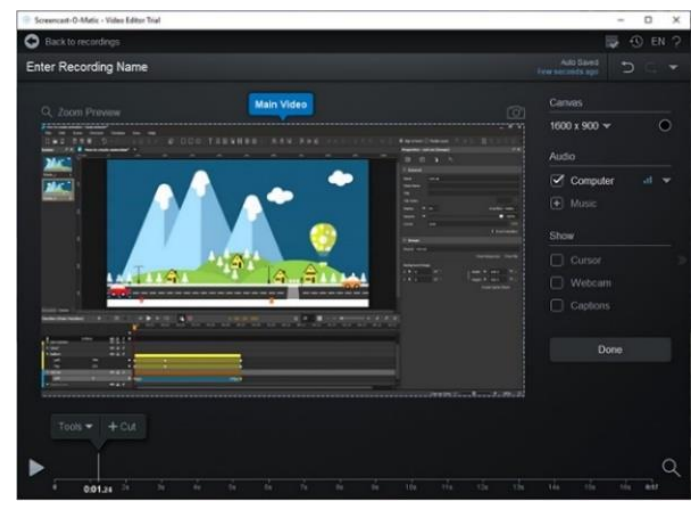

Gambar 3: aplikasi Screencast-0-matic

Keniscayaan bagi guru untuk selalu berkembang seiring laju cepatnya teknologisemakin tidak terbantahkan di masa pandemi Covid-19 ini. Sebelum pandemi ajakan untuk mengembangkan teknologi kepada para guru seakan jalan di tempat, namun pada saat pandemi ini, mereka pun harus "dipaksa" mengembangkan diri demi untuk bisa memberikan pembelajaran yang terbaik kepada peserta didik mereka.

Apabila boleh dikatakan, salah satu hikmah pandemi Covid-19 di masa perkembangan tekonolgi ini adalah terbukanya hati dan pikiran para guru sebagai manusia pendidik tentang betapa pentingnya mengembangkan diri, terutama mengikuti perkembangan iptekom di 
masa kini. Guru yang tidak mau membuka diri dengan perekmbangan iptekom tidak mungkin dapat memberikan pembelajaran terbaiknya kepada peserta didik.

\section{DAFTAR PUSTAKA}

ArsyadAzhar. M.A. 2006. Media Pembelajaran. Jakarta: PT Raja Grafindo.

Heinich, dkk. 1982. Instructional Media and The New Technologies of Instruction. New York: John Willey \& Sons.

Mokhtar, S. B. 2017. Teaching-Learning Model of Islamic Education at Madrasah Based on Mosque in Singapore. International Journal of Asian Social Science, 7(3), 218-225. 
50 | Akademisi dalam Lingkaran Daring 


\title{
PENGUATAN KOMPETENSI GURU PADA MASA PANDEMI COVID-19
}

\author{
Ahmad Fawaid, M.Pd.I ${ }^{7}$ \\ (Fakultas Tarbiyah IAIN Madura)

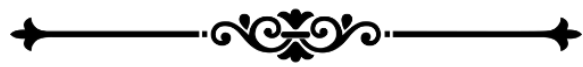

"Dibutuhkan kompetensi guru untuk menjamin pembelajaran baik. Guru menjadi aspek utama yang memastikan proses pendidikan bermutu atau pun tidak, sebab guru berhadapan langsung dengan peserta didik dalam proses pembelajaran. Kompetensi yang harus dimiliki guru adalah kompetensi kepribadian, professional dan sosial"

\begin{abstract}
$\mathrm{D}$ alam masa pandemi covid-19, peran guru dalam proses pembelajaran menjadi lebih berat. Guru dituntut melaksanakan proses pembelajaran yang berkualitas, inovatif dan bermutu yang tidak pernah terpikirkan sebelum-sebelumnya. Guru didorong melaksanakan pembelajaran secara daring yang membutuhkan keahlian dalam menggunakan teknologi.
\end{abstract}

\footnotetext{
${ }^{7}$ Penulis lahir di Sumenep Madura Pada Tanggal 12 Agustus 1988. Sekarang Berdomisili di Bugih Pamekasan, Dosen di IAIN Madura Pada Fakultas Tarbiyah, Menyelesaikan Sarjana Pendidikan pada Tahun 2011 di STAIN Pamekasan (Sekarang IAIN Madura) dan Mendapatkan Gelar Magister Pendidikan Pada Tahun 2013 di IAIN Surabaya (Sekarang UINSA). Sekarang menjabat sebagai Sekretaris Prodi Pendidikan Guru Madrasah Ibtidaiyah (PGMI) Fakultas Tarbiyah IAIN Madura.
} 
Disisi lain, seringkali guru dihadapkan pada kondisi dimana banyak dari peserta didiknya mengeluh dalam melaksanakan pembelajaran daring. Kendati demikian, guru harus tetap berusaha menjalankan peran, tugas dan fungsinya sebagai pendidik serta menjamin terpenuhinya kebutuhan siswa dalam proses pembelajaran dengan sebaik-baiknya.

Dan untuk menjamin pembelajaran dengan baik seperti demikian, dibutuhkan suatu kompetensi guru. Dimana kompetensi merupakan perpaduan dari pengetahuan, keterampilan, nilai dan sikap yang direfleksikan dalam kebiasaan berpikir dan bertindak (Mulyasa: 2003-37). Sedangkan kompetensi guru merupakan kemampuan seorang dalam melaksanakan kewajiban kewajiban serta bertanggung jawab dan layak mengajar dan juga sebagai kemampuan dan kewenangan guru dalam menjalankan profesi keguruannya berdasarkan potensi keilmuan yang dimilikinya (Akmal Hawi, 2014:77). Kompetensi juga dapat diartikan sebagai suatu kemampuan yang harus dimiliki sesuai dengan standar kinerja yang diisyaratkan dan merupakan suatu keniscayaan bagi seorang guru dalam menjalankan pembelajaran.

Dalam pembelajaran, guru memiliki peranan yang besar serta strategis. Perihal ini dikarenakan gurulah yang terletak pada barisan terdepan dalam penerapan pembelajaran. Guru jadi aspek utama yang memastikan proses pendidikan bermutu ataupun tidak, sebab guru berhadapan langsung dengan peserta didik dalam proses pembelajaran. Dan dalam membentuk kecerdasan, kecakapan serta kepribadian siswa, butuh guru yang bertanggung jawab, terampil, serta berdedikasi besar dalam menjalankan kompetensinya.

Oleh sebab itu, guru dituntut mempunyai persyaratan kompetensi dasar supaya bisa dikatakan 
selaku orang yang handal dalam melakukan aktivitas belajar mengajar. Perihal ini sebab berkaitan dengan bagaimana memakai ilmu yang dimilikinya buat meningkatkan keahlian terpendam peserta didik. Sebagaimana tertuang dalam Undang- Undang Republik Indonesia No 20 Tahun 2003 tentang Sistem Pembelajaran Nasional, secara implisit disebutkan persyaratan seseorang guru, ialah mempunyai kualifikasi serta sertifikasi minimun dengan jenjang kewenangan mengajar, sehat jasmani, rohani, serta mempunyai keahlian mewujudkan tujuan pembelajaran nasional. Persyaratan tersebut merupakan:

a. Guru wajib mempunyai kualifikasi akademik, kompetensi, sertifikasi guru, sehat jasmani serta rohani dan mempunyai keahlian mewujudkan tujuan pembelajaran nasional

b. Kualifikasi akademik yang diperoleh lewat program sarjana pembelajaran besar ataupun program diploma empat

c. Kompetensi guru meliputi, kompetensi pedagogik, kompetensi karakter, kompetensi sosial serta kompetensi handal yang diperoleh lewat pembelajaran profesi.

d. Sertifikat pendidik diberikan kepada guru yang sudah penuhi persyaratan yang sertifikasinya dilaksanakan oleh akademi besar yang mempunyai program pengadaan tenaga kependidikan yang terakreditasi serta diresmikan. Sertifikasi ini dicoba secara obyektif, transparan serta akuntabel.

Dalam Pasal 8 UU Nomor. 14 Tahun 2005, kompetensi yang wajib dipunyai seseorang guru dalam mengajar, ialah seseorang pendidik/ guru wajib mempunyai kompetensi sosial, karakter, handal serta pedagogic (Mulyasa, 2007: 40). Dari keempat 
kompetensi tersebut bisa dijabarkan berikut: Pertama, Kompetensi sosial, dalam kompetensi ini diharapkan seseorang guru bisa jadi faktor semangat peserta didik dengan membagikan pengajaran tentang bahasa serta norma- norma dalam bersosialisasi baik di sekolah ataupun di luar sekolah. Kedua, Kompetensi keperibadian atau karakter, seseorang guru wajib mempunyai keperibadian yang berwibawa, sebab guru ialah sorotan serta teladan untuk peserta didiknya. Ketiga, Kompetensi profesional, dalam kompetensi ini seseorang guru wajib sanggup memahami kondisi dikala mengajar. Tidak hanya itu guru pula wajib memahami materi pelajaran dan mempunyai interpretasi yang besar supaya aktivitas belajar mengajar bisa berlangsung dengan baik. Keempat, Kompetensi Pedagogik, dalam perihal ini guru wajib memberikan pemahaman kepada peserta didik dengan mengaktualisasikan pengetahuan yang dimilikinya ke dalam pengajaran dialogis. Sanggup menggunakan teknologi, meningkatkan kurikulum serta mengevaluasi pendidikan.

Pada masa pandemi covid-19 ini, empat kompetensi yang harus dimiliki guru tesebut diperlukan penguatan kembali pada diri seorang guru terutama kompetensi professional dan kompetensi pedagogik. Kompetensi profesional merupakan penguasaan materi pembelajaran secara luas dan mendalam yang harus dikuasai oleh guru, termasuk penguasaan mata pelajaran kurikulum di sekolah dan substansi keilmuan yang meliputi materi, serta penguasaan struktur dan metodologi keilmuan. dengan kompetensi profesional ini, materi pelajaran bisa tersampaikan dan bisa dipahami oleh peserta didik dan juga terjaminnya kegiatan belajar mangejar dapat berlangsung dengan baik. (Suyanto dan Jihad Asep, 2013:41) 
Bagitu juga dengan kompetensi pedagogik, kompetensi ini sangat menentukan efektivitas dan efisiensi pembelajaran di masa pandemi yang mengharuskan penggunaan pendekatan teknologi. Seperti halnya perangkat computer, laptop, gadget yang terkoneksi dengan koneksi jaringan internet, peserta didik dapat belajar bersama secara mandiri. E-learning dilakukan secara bersamaan dengan menggunakan grup di media sosial seperti Whatsapp, telegram, aplikasi Zoom atau media sosial lainnya sebagai sarana pembelajaran sehingga dapat memastikan siswa belajar dalam waktu yang bersamaan meskipun berada di tempat yang berbeda (Rahayu, 2020:21)

Penguatan ranah kompetensi pedagogik merupakan suatu keniscayaan untuk menjawab perkembangan ilmu pengetahuan dan teknologi terutama pada masa pandemi covid-19 yang tentunya memiliki konsekuensi logis terhadap orientasi pengembangan kompetensinya yang jadi karakteristik seseorang guru yang handal. Sehingga dapat menjamin pembelajaran yang bermutu serta sesuai dengan tuntutan perubahan jaman, peningkatan kompetensi ini ialah proses yang berkelanjutan.

Sehingga dengan penguatan pada dua kompetensi diatas tersebut, meskipun pembelajaran berada pada masa pandemic covid-19 guru akan mampu mendesain pembelajaran, dan mengembangkan pengalaman belajar dengan menggunakan pendekatan teknologi, menjadi model cara belajar dan bekerja di era digital, mendorong dan menjadi model tanggung jawab dan masyarakat digital, berpartisipasi dalam pengembangan dan kepemimpinan professional.

Oleh karena itu, penguatan kompetensi guru, khususnya kompetensi profesional dan pedagogik pada masa pandemi ini tidak dapat dielakkan lagi guna 
tingkatkan kualitas pendidikan serta menggapai citacita pendidikan nasional. Guru diharapkan terus tingkatkan kompetensinya, harus memiliki keahlian khusus dalam menjalankan tugas profesionalnya, terutama penguasaan teknologi dan informasi. Mengingat peran strategis yang dimiliki seorang guru sangat urgen agar peserta didik tetap termotivasi untuk belajar dan dapat mengembangkan minat bakat dalam dirinya serta mencetak peserta didik yang unggul. Maka upaya penguatan untuk membekali dan mengembangkan profesionalisme guru sangat penting untuk terus dilakukan.

\section{DAFTAR PUSTAKA}

Hawi, Akmal. 2014. Kompetensi guru agama islam. Jakarta: Rajawali Press.

Mulyasa, E. 2003. Kurikulum Berbasis Kompetensi. Bandung: Remaja Rosdakarya.

........... .. 2007. Standar Kompetensi dan Sertifikasi Guru. Bandung: Remaja Rosdakarya.

Suyanto, Jihad Asep. 2013. Menjadi guru Profesional: strategi meningkatkan kualifikasi dan kualitas di era digital. Jakarta: Penerbit Erlangga. 


\title{
OPTIMALISASI PENDEKATAN PEMBELAJARAN STEM SECARA DARING SAAT PANDEMI
}

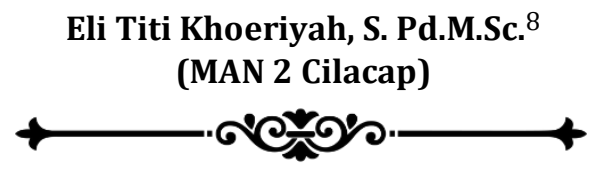

"Pembelajaran berbasis STEM (Science, Technology, Enginering and Mathematic) secara daring darirumah saat pandemi covid bisa mengoptimalkan peserta didik semakin berkreasi, kreatif dan trampil dalam kemampuan sains."

\begin{abstract}
Tirus Covid 19 telah menjadi disrupsi yang terbesar di abad ini yang telah membawa kita semua pada normal baru yang sekarang menjadi hal yang dalam kehidupan sehari - hari. Kehidupan manusia sangatlah berefek akibat adanya pandemi Covid 19 dalam segala bidang baik bidang pariwisata, perekonomian, beribadah, pendidikan ataupun bidang lainnya. Dibidang pendidikan sangatlah berefek mulai dari jenjang TK, SD, SMP, SMA bahkan perguruan tinggi. Kita semua menyadari bahwa pandemi covid 19 ini betul -

${ }^{8}$ Penulis kelahiran Cilacap 13 September 1979 ini merupakan guru pengampu Mata Pelajaran Fisika di MAN 2 Cilacap. Menyelesaikan pendidikan jenjang Sarjana di UNNES Semarang dan Pascasarjana di UGM Yogyakarta.
\end{abstract}


betul menciptakan satu kondisi baru yang belum pernah kita rasakan sebelumnya, dimana kita harus tinggal di rumah berminggu- minggu bahkan berbulan - bulan, menjaga jarak, tiba-tiba sadar tentang kebersihan,kesehatan tentang perilaku hidup bersih sehat.

Pemerintah menganjurkan setiap orang mengikuti protokol kesehatan physical distancing sehingga dibidang pendidikan mengalami perubahan pada pembelajaran terhadap peserta didik sangatlah signifikan dari pembelajaran konvensional tatap muka menjadi pembelajaran daring atau pembelajaran jarak jauh. Proses pembelajaran daring dirumah lebih ke arah bagaimana memaknai proses pembelajaran itu sendiri jadi tidak ditargetkan kurikulum atau target untuk konten - konten pembelajaran, tapi sebenarnya situasi tertentu yang harus dilakukan sementara itu kemudian partisipasi pendidikan milik kita semua. Selama ini pendidikan diserahkan kepada pendidik atau sekolah ,kini saatnya yang tepat bagaimana peran serta orang tua atau peran serta dari anggota keluarga yang lain. Memang butuh waktu dan penyesuaian. Proses pembelajaran antara pendidik dan peserta didik tidak bisa digantikan secara total, pembelajaran daring atau pembelajaran jarak jauh salah satu metode yang bisa dijadikan untuk bisa terjadinya proses pembelajaran tapi memang untuk penguatan karakter perlu adanya interaksi antara pendidik dan peserta didik. Buat evaluasi proses pembelajaran disekolah apakah siswa diajarkan untuk cara belajar kreatif, kritis didalam menghadapi berbagai situasi, kalau memang anak anak sudah terbiasa dengan cara berpikir kreatif dan pendidik atau guru nya terbiasa dengan modifikasi atau inovasi pembelajaran tertentu dengan situasi pandemi ini maka guru atau pendidik bisa menyesuaikan 
bagaimana proses pembelajaran apa yang kira- kira tepat disituasi saat ini.

Dari forum ekonomi dunia (2018) 65\% peserta didik yang saat ini duduk di bangku Sekolah Dasar (SD) akan bekerja pada bidang yang saat ini belum tercipta. Dengan demikian bisa disimpulkan bahwa peserta didik saat ini tidak bisa lagi disiapkan sebagai pencari kerja melainkan harus kita siapkan sebagai pencipta kerja atau sebagai inovator. Untuk bisa menjadi inovator tentunya tidak lepas dari taksonomi yang sering kita dengar HOTS (Higher Oerder Thinking Skills), dimana ada 6 level tingkat berpikir manusia dari mulai level rendah sampai level tinggi (C1 sampai C6) yaitu level mengingat, memahami, mengaplikasi, menganalisis, mengevaluasi dan mencipta. Melihat tantangan di abad 21 yang sering disebut revolusi industri 4.0 ternyata anak- anak atau peserta didik kita harus mencapai di level C 6 karena mereka harus bisa menjadi pencipta kerja. Proses pendidikan seperti ini adalah proses yang dibutuhkan di era revolusi 4.0 yaitu dari level C4 sampai C6 yang harus dimiliki setiap peserta didik yang sering muncul istilah HOTS (Higher Order Thinking Skills). Kalau kita sudah berpikir dilevel nalar tingkat tinggi kita membutuhkan ketrampilan - ketrampilan di abad 21 yang sering dikenal 4 C yaitu berpikir kritis, berkolaborasi, berkemampuan komunikasi dan kemampuan untuk kreatif. Empat skil atau ketrampilan ini yang disebut ketrampilan abad 21, ketrampilan yang harus dimiliki di era digital ini.

Berdasarkan kajian Bank Dunia ketrampilan yang dibutuhkan didunia kerja saat ini ada 8 ketrampilan ynag dikenal dengan istilah PRACTICS yaitu :Problem Solving (Memecahkan masalah), Resillience (Katangguhan), Achievemen Motivation (Motivasi berprestasi), Control (Mengendalikan), Team Work 
(Bekerja sama), Initiative (Prakarsa), Confidence (Kepercayaan diri) dan Ethics (Etika). Pendekatan pembelajaran di abad 21 yang paling cocok untuk diterapkan dalam kelas - kelas tradisional maupun kelas modern guna meningkatkan kecakapan abad 21 peserta didik adalah pendekatan pembelajaran STEM (Science, Technology, Enginering and Mathematic).

Selama pandemi Covid 19 ini bidang pendidikan telah melakukan pembelajaran secara daring atau online yaitu pembelajaran jarak jauh yang sesuai dengan kebijakan menteri pendidikan 9 maret 2020 dengan kita tetap mendorong semangat untuk merdeka belajar. Belajar dirumah selama pandemi ini bisa diwujudkan dalam berbagai cara salah satunya pembelajaran STEM (Science, Technology, Enginering and Mathematic) secara daring. Pembelajaran daring dirumah agar pembelajarannya bermakna dan kreatif maka peserta didik diharapkan dalam pembelajarannya berbasis STEM (Science, Technologi, Enginering dan Mathematic) sehingga dengan ketrampilannya bisa menghadapi perkembangan teknologi di abad 21. Secara garis besar semua daerah di Indonesia melakukan pembelajaran secara daring, untuk itu penting bagi pendidik dan peserta didik dalam mempersiapkan pembelajaran daring yang dilakukan dirumah dapat berjalan efektif dan efisien. Yang perlu disiapkan peserta didik yaitu tempat belajar yang nyaman sehingga akan membuat konsentrsi meningkat, usahakan belajar di meja, tata rapi dan siapkan perlengkapan, selalu membuat reminder karena sangat penting sehingga dapat membanatu mengatur waktu dengan baik, memastikan koneksi internet dengan belajar, koneksi internet yang baik akan membuat proses belajar menjadi lancar dan menjauhkan diri dari distraksi/ gangguan. 
Peran guru atau pendidik tidak akan lepas pada setiap kegiatan pembelajaran dari proses pelaksanaan pendidikan peserta didik belajar. Apa yang diajarkan pendidik akan sangat berpengaruh apa yang dipelajari peserta didik. Maka diperlukan kreativitas, kepiawaian pendidik dalam mengolah, mengemas pembelajaran daring menjadi efektif sehingga akan tercapainya tujuan kurikulum dengan menghasilkan aktivitas-aktivitas peserta didik dalam pembelajaran jarak jauh atau daring untuk membangun pengetahuan. Salah satu cara untuk mempermudah belajar sains, peserta didik dan guru dapat merancang dan membuat alat pelajaran sendiri dengan bahan sederhana yang ada disekitarnya sehingga akan menghasilkan produk yang sesuai dengan apa yang sedang dipelajari. Inovasi pendidik yang dapat mempermudah peserta didik memahami dan menguasai materi yang diajarkan dengan cara peserta didik membuat dan menggunakan alat peraga dalam proses pembelajaran. Peserta didik akan menerima pengalaman dalam belajar dan akan semakin memahami serta menguasai mendalami materi-materi pelajaran yang sedang diajarkan. Supaya lebih mudah memahami materi pelajaran peserta didik harus memiliki pengalaman belajar, seperti kejadian-kejadian yang sifatnya kongkrit, mengamati benda-benda secara langsung, dan mengetahui penerapan materi tersebut dalam kehidupan sehari-hari. Agar proses pembelajaran dapat mempermudah peserta didik menguasai apa yang disampaikan oleh pendidik akan memerlukan pendekatan pembelajaran yang tepat. Pendekatan yang tepat salah satunya adalah pembelajaran berbasis STEM (Science, Technoligy, Enginering and Mathematic) sehingga pembelajaran abad 21 tercapai. Pembelajaran berbasis STEM (Science, Technology, Enginering and Mathematic) dapat menghadirkan pembelajaran abad 21 karena bisa 
mengintegrasikan ilmu pengetahuan, teknologi, enginering dan matematik dalam pembelajaran sains.

Pembelajaran STEM (Science, Technology, Enginering and Mathematic) secara daring adalah salah satu pembelajaran yang efektif yang bisadilakukan dimasa pandemi covid. Pendidik berkreatif dalam memberikan proyek kepada peserta didik dengan melibatkan science, teknologi, enginering dan mathematic.Dengan pembelajaran STEM (Science, Technology, Enginering and Mathematic) secara daring dapat meningkatkan hasil belajar dan aktivitas peserta didik di masa pandemi sehingga akan tercipta pembelajaran yang bermakna.

Dengan adanya integrasi pembelajaran STEM (Science, Technology, Enginering and Mathematic) diharapkan dapat memaksimalkan penerapan dalam sehari hari mata pelajaran tersebut yang berupa alat peraga dengan menggunakan bahan sederhana sehingga pembelajaran menjadi efektif, efisien, sederhana dan mudah dipahami peserta peserta. Pendekatan pembelajaran STEM merupakan pembelajaran pada peserta didik agar dapat mempersiapkan dalam pengembangan skill atau ketrampilan yang diperlukan dalam berkompetisi pada kemajuan teknologi abad 21 (Sander, 2009,Becker dan Park , 2011).

Ada beberapa kerangka berpikir bagi peserta didik dalam pembelajaran STEM (Science, Technology, Enginering and Mathematic) :Peserta didik menemukan masalah dan mendiskusikannya, Peserta didik merencanakan rancangan eksperimen yang akan dilakkan, Peserta didik membuat langsung rangkaian percobaan, Peserta didik dapat menguji dan mendapatkan hasil dan dapat mengkomunikasikannya dengan peserta didik lainnya. 
Langkah -langkah yang harus dilakukan dalampembelajaran STEM (Science, Technology, Enginering and Mathematic) agar peserta didik aktif, kreatif, inovatif dan trampil sehingga akan dapat mengembangkan ketrampilan peserta didik dalammenghadapi kemajuan teknologi abad 21:

1. Identifikasi berbagai Kompetensi Dasar (pengetahuan dan ketrampilan) yang sesuai dengan pembelajaran berbasis STEM (Science, Technology, Enginering and Mathematic)

2. Identifikasi topik yang sesuai dengan Kompetensi Dasar

3. Rumuskan topik yang sesuai dengan Kompetensi Dasar

4. Analisi STEM (Science, Technology, Enginering and Mathematic) pada topik terpilih

5. Pikirkan masalah sehari - hari yang terkait dengan topik tersebut

6. Tentukan judul aktivitas berdasarkan rumusan masalah

7. Buat pemetaan konsep Sains, Teknologi, Enginering dan Matematik

8. Tetapkan variabel bebas dan terkait yang menantang peserta didik untuk bereksperimen

9. Pikirkan alat dan bahan yang perlu disiapkan

10.Desain urutan pembelajaran ( RPP)

Manfaat bagi peserta didik pada pembelajaran berbasis STEM ( Science, Technology, Enginering and Mathematic ) adalah :Melatih peserta didik menemukakn konteks masalah untuk mulai meneliti, menyelidiki, menginvestigasi; Melatih peserta didik memilih bacaan atau mengumpulkan informasi dari 
sumber yang relevan; Melatih peserta didik menemukan proses pembelajaran dan menentukan apa yang masih belum diketahui; Melatih peserta didik dalam menyelesaikan atau memecahkan suatu masalah yang terjadi;Peserta didik bisa menguji model yang dirancang berdasarkan hasil pengujian; Peserta didik bisa mengulang ke langkah sebelumnya; Peserta didik dapat mengembangkan ketrampilan berkomunikasi dan berkolaborasi serta mampu menerima dan menerapkan umpan balik yang membangun. Dengan pembelajaran STEM (Science, Technology, Enginering and Mathematic) secara daring darirumah saat pandemi covid bisa mengoptimalkan peserta didik semakin berkreasi, kreatif dan trampil dalam kemampuan sains.

\section{DAFTAR PUSTAKA}

Becker,K \& Park, K (2011),Effects of integrative approaches among science, technology, engineering an mathematics ( STEM) subjects on students' learning : A preminary meta-analysis, Journal of STEM Education, 12 ( 5 \& 6)

Sanders, M (2009) STEM, STEM education, STEM mania, The Technology Teacher,68 (4) 


\title{
KOLABORASI ANTARA GURU DAN ORANG TUA DALAM PROSES PEMBELAJARAN SELAMA PANDEMI
}

\author{
Dyah Normaning Poncorini, S.Pd ${ }^{9}$ \\ (SMP Negeri 06 Batu)

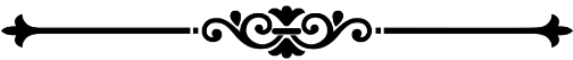

"Selain guru, orang tua memiliki peranan yang sangat penting dalam keberlangsungan kegiatan pembelajaran daring. Karena pada saat kegiatan daring berlangsung peserta didik berada di wilayah lingkungan orang tua dan orang tua secara langsung wajib memperhatikan kegiatan belajar anak di rumah.

$\mathrm{M}$ asa pandemi dimulai sejak bulan Maret 2020 ketika corona virus disease 2019 (Covid-19) ditetapkan sebagai wabah virus nasional. Wabah ini menular begitu cepat hampir ke seluruh Negara di dunia termasuk Indonesia. Akibat dari wabah ini, berbagai Negara melakukan berbagai perubahan besar di berbagai bidang, seperti ekonomi, teknologi, pariwisata, pendidikan, dll. Berbagai macam kebijakan telah diputuskan oleh pemerintah untuk menanggulangi

${ }^{9}$ Penulis lahir di Malang, 15 Januari 1982, penulis merupakan guru mata pelajaran Bahasa Daerah (Jawa) di SMP Negeri 06 Batu, penulis menyelesaikan gelar Sarjana Pendidkan Bahasa dan Sastra Indonesia dan Daerah di Universitas Negeri Malang (2005 
berbagai dampak yang bermunculan akibat penyebaran Covid-19 diantaranya pembatasan aktivitas, himbauan untuk selalu menjaga kebersihan diri, social distancing, physical distancing, karantina wilayah, bekerja dari rumah, hingga pembatasan mobilitas masyarakat (BBC.2020)

Pada sektor pendidikan, pemerintah menerapkan kebijakan belajar dari rumah atau yang sering kita sebut dengan BDR. Kebijakan ini diterapkan bagi seluruh pelajar mulai tingkat PAUD sampai dengan Perguruan Tinggi yang berada di zona merah, kuning, dan orange dengan mengacu pada keputusan bersama empat menteri tentang Panduan Penyelenggaraan Pembelajaran pada Tahun 2020/2021 di masa Covid19. Satuan pendidikan yang berada di zona berwarna hijau dapat melaksanakan kegiatan pembelajaran secara tatap muka dengan memperhatikan protocol kesehatan.

Sejalan dengan kebijakan belajar dari rumah tersebut munculah istilah belajar daring (dalam jaringan/online) dan luring (luar jaringan/offline). Pembelajaran daring bertujuan untuk menyediakan layanan pembelajaran secara online untuk menarik perhatian peserta didik. Dalam pembelajaran daring ada beberapa hal yang harus dipenuhi antara lain adanya peserta didik, guru, teknologi, dan orang tua. Selain guru, orang tua memiliki peranan yang sangat penting dalam keberlangsungan kegiatan pembelajaran daring. Karena pada saat kegiatan berlangsung peserta didik berada di wilayah lingkungan orang tua dan orang tua secara langsung wajib memperhtikan kegiatan belajar anak di rumah.

Menurut Baumrind dalam penelitian yang dilakukan Wiwin Yulianingsih, dkk. 2021 menyampaikan bahwa peran keluarga tidak dapat tergantikan meskipun anak 
telah belajar di lembaga pendidikan formal maupun nonformal. Sebagai pengasuh dan pembimbing dalam keluarga, meletakkan dasar-dasar perilaku bagi anak, sikap, dan kebiasaan orang tua akan selalu dilihat, dinila, dan ditiru oleh anak. Pada proses pembelajaran yang dilakukan secara daring, kegiatan belajar yang dilakukan anak menjadi tanggung jawab orang tua. Hal ini menuntut kesiapan orang tua dalam memberikan layanan kepada putra-putri mereka. Dari sini munculah hal baru bahwa tidak semua orang tua siap menjalankan pekerjaan rumah, pekerjaan kantor, sekaligus menjadi guru pengganti selama kegiatan belajar dari rumah berlangsung. Akhirnya sangat dibutuhkanlah kolaborasi antara guru dan orang tua dalam proses pembelajaran dari rumah.

Hal-hal yang dapat dilakukan orang tua antara lain membuat jadwal belajar anak di rumah, memberikan bantuan belajar, pemahaman spiritual, pengawasan, motivasi, dan fasilitas dalam belajar. Pemberian bantuan belajar dapat dilakukan dengan cara memperhatikan kesulitan putra-putrinya dalam menyelesaikan tugas/materi, kemudian memberikan penjelasan dan pemahaman atas materi tersebut. Dalam hal ini muncullah beberapa kendala yang dapat dialami oleh orang tua dalam memberikan pendampingan kepada putra-putrinya selama masa pandemi ini. Antara lain yaitu kurangnya waktu kebersamaan orang tua dengan putra-putrinya di rumah. Orang tua yang bekerja tidak bisa mendampingi putra-putrinya secara maksimal karena kesibukan dan jadwal pekerjaan yang terlalu lama. Sehingga putra-putri mereka tidak terlalu mengikuti proses pembelajaran dengan baik.

Kendala kedua bisa berupa kesulitan orang tua dalam memahami materi pembelajaran putra-putrinya. Hal ini disebabkan oleh latar belakang pendidikan orang 
tua yang berbeda-beda. Ada pesertadidik yang memiliki orang tua terpelajar, ada juga yang memiliki orang tua buta huruf, putus sekolah, atau yang lainnya. Berdasarkan ilustrasi masalah di atas, guru dapat bekerjasama dengan orang tua. Saling berkoordinasi melalui video call secara terjadwal atau melalui sms, watsapp group, maupun media social lainnya untuk mengatahui berbagai kendala yang dialami peserta didik selama proses pembelajaran daring berlangsung. Proses belajar di masa seperti ini sangat menuntut orang tua agar segera pulang ke rumah setelah pulang bekerja agar dapat memberikan pendampingan yang maksimal bagi putra-putrinya. (Asmuni. 2020).

Keterlibatan orang tua merupakan proses orang tua untuk mengerahkan kemampuannya dalam menyediakan keperluan dirinya sendiri, anak, serta program yang sedang dijalani oleh anak (Patmonodewo, 2003) Jadi dalam proses pembelajaran daring di masa pandemi ini, kolaborasi antara guru dan orang tua dalam proses pembelajaran mutlak harus dilaksanakan untuk mengawal, membimbing, dan memberi motivasi kepada peserta didik demi tercapainya tujuan pendidikan nasional. ***

\section{DAFTAR PUSTAKA}

Asmuni. 2020. Problematika Pembelajaran Daring di masa Pndemi Covid-19 dan solusi pemecahannya. Jurnal Pedagogy Volume 7 No. 4. Doi: 10.33394/jp.v7i4.2941

BBC. 2020. Virus Corona: "Status Kedaruratan Kesehatan Masyarakat" dan Pembatasan Sosial Baerskala Besar, yang boleh dan tidak boleh BBC News Indonesia. BBC News Indonesia. 
https://www.bbc.com/indonesia/indonesia52109439

Patmonodewo, S. 2003. Pendidikan Anak Pra Sekolah. Jakarta: Rineka Cipta

Yulianingsih, Wiwin. Suhanadji. Nugroho, Rivo. Mustakim. 2021. Keteribatan Orang tua dalam Pendampingan Belajar Anak selama Masa Pandemi Covid-19. Jurnal Obsesi: Jurnal Pendidikan Anak Usia Dini Volume 5 Issue 2 Pages 1138-1150. Doi: 10.31004/obsesi.v5i2.740 
70 | Akademisi dalam Lingkaran Daring 


\section{MEMBIASAKAN HAL YANG TIDAK BIASA DALAM MATA PELAJARAN PRODUK KREATIF DAN KEWIRAUSAHAAN}

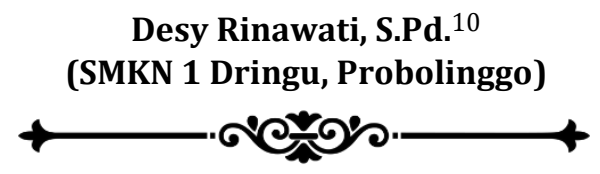

"Pembelajaran produk kreatif dan kewirausahaan pada masa pandemi Covid-19 ini memerlukan inovasi untuk menciptakan mindset siswa terkait ekonomi yang keberlanjutan di tingkat nasional"

\footnotetext{
Corona, atau yang biasa dikenal dengan Covid 19, telah menginfeksi Indonesia. Terhitung setahun lebih sejak kasus pertama diumumkan pada tanggal 2 Maret 2020 oleh Menteri Kesehatan saat itu, Letjen TNI (Purn) Dr. dr. Terawan Agus Putranto, Sp.Rad (K) RI. Manusia adalah makhluk sosial yang selalu berinteraksi dengan sesamanya. Interaksi disini dapat berupa interaksi secara langsung maupun tidak langsung. Salah satu hal yang memungkinkan penyebaran Covid 19

${ }^{10}$ Penulis lahir di Probolinggo, 8 Desember 1989, penulis merupakan Guru Mata Pelajaran Produk Kreatif dan Kewirausahaan di SMKN 1 Dringu, Kabupaten Probolinggo. Penulis menyelesaikan gelar Sarjana Pendidikan Ekonomi di Universitas Negeri Surabaya (2012), penulis tercatat sebagai ASN sejak tahun 2018 hingga sekarang.
} 
semakin meluas adalah adanya interaksi tersebut. Droplet, maupun airborne disinyalir memperparah menjadi cara penyebaran Covid 19 yang memperparah situasi pandemi di Indonesia ini. Semakin pesatnya penyebaran Covid 19, memaksa Pemerintah mengambil langkah tegas dengan "merumahkan" para pekerja atau dikenal dengan istilah work from home. Tidak hanya para pekerja, namun juga untuk sekolah dan perkuliahan, pelajar dari semua jenjang pendidikan diharuskan untuk belajar dari rumah. Hal ini bertujuan untuk memutus mata rantai virus corona agar tidak menyebar semakin luas.

Kementerian Pendidikan di bawah kepemimpinan Nadiem Makarim, menggaungkan semangat peningkatan produktivitas bagi siwa untuk mengangkat peluang kerja ketika menjadi lulusan sebuah sekolah, salah satunya adalah siswa lulusan SMK. Namun sekali lagi, dengan hadirnya Covid 19, maka dunia pendidikan Indonesia perlu mengikuti alur yang sekiranya mampu menolong kondisi sekolah dalam keadaan darurat. Sekolah perlu memaksakan diri menggunakan media daring untuk tetap melakukan proses pembelajaran. Tetapi seperti yang kita ketahui bersama, penggunaan media daring dalam proses pembelajaran bukannya tanpa masalah, banyak sekali permasalahan yang muncul karena kita belum terbiasa. Salah satu mata pelajaran di SMK adalah produk kreatif dan kewirausahaan. Proses pembelajaran selama ini berlangsung secara langsung, dengan bertatap muka agar lebih mudah mengarahkan dan membimbing produk apa yang akan mereka hasilkan. Mulai dari sikap dan perilaku seorang wirausaha, memahami peluang usaha yang ada, proses bagaimana mereka menemukan ide atau gagasan bisnis mereka bagaimana mendesain sebuah produk, kemudian bagaimana proses kerja pembuatan prototype produk mereka, hingga finalisasi 
produk dan cara promosi menjadi rangkaian kegiatan yang dilakukan pada mata pelajaran ini (Fauzia dkk., 2017).

Produk kreatif dan kewirausahaan memainkan peran penting dalam membentuk siswa menjadi wirausaha, menjadikan wirausaha mampu dilaksanakan melalui pendidikan vokasional di SMK, yang nantinya akan memunculkan keahlian dalam bisnis melalui aktivitas yang dijalankan. Secara umum, tugas seorang guru disini adalah membantu siswa menemukan ide atau gagasan produk yang akan mereka siapkan, hasil dari analisis peluang usaha yang muncul. Pendampingan serta bimbingan secara langsung oleh guru diperlukan, mengingat pada mata pelajaran ini memang output pembelajarannya adalah produk yang dapat dikomersilkan. Guru perlu memiliki kemampuan untuk menyampaikan kompetensi dalam mata pelajaran produk kreatif dan kewirausahaan. Metode pembelajaran yang diberikan berbentuk pengalaman yang sesuai untuk pendidikan dan latihan menjadi seorang wirausahawan.

Tetapi, itu semua bisa dilakukan pada masa sebelum pandemi. Kini, pandemi menyerang Indonesia serta mengharuskan proses pembelajaran berlangsung secara daring, memunculkan beberapa kesulitan, diantaranya sebagai berikut. Yang pertama adalah karena mata pelajaran produk kreatif dan kewirausahaan ini lebih menekankan kepada praktek, maka dengan proses pembelajaran yang berlangsung secara daring menyulitkan siswa untuk memahami setiap tahapan dan prosesnya. Melalui aplikasi seperti zoom atau google meet sekalipun, tidak dapat banyak membantu siswa, mereka membutuhkan bimbingan secara langsung / face to face dengan guru. 
Berikutnya adalah dari segi sinyal. Seperti diketahui bersama, dalam proses pembelajaran daring ini semua dilakukan berbasis internet. Yang artinya bahwa, jangkauan internet dan kekuatan sinyal akan mempengaruhi kualitas pembelajaran daring. Tidak semua siswa tinggal di lingkungan yang termasuk dalam kategori "sinyal kuat". Akhirnya, proses pembelajaran tidak dapat berlangsung secara maksimal karena adanya gangguan sinyal tersebut. Hambatan ketiga yang seringkali dirasakan adalah tidak semua siswa memiliki smartphone yang memadai untuk pembelajaran daring seperti ini. Hal ini juga dapat mempengaruhi kualitas pembelajaran untuk mata kuliah praktek di SMK. Dan yang terakhir adalah kurangnya pendampingan dari orang tua pada saat pembelajaran daring berlangsung. Inilah yang dapat menjadi penyebab tidak maksimalnya produk yang mereka gagas dan rencanakan di awal. Kendala terakhir yang paling banyak dirasakan ketika pandemi ini adalah kejenuhan. Seperti dalam penelitian (Rinawati \& Darisman, 2020) pembelajaran produk kreatif dan kewirausahaan di SMKN 1 Dringu yang biasanya berlangsung secara langsung, kini diharuskan untuk dilakukan secara daring. Hal ini diduga memicu kejenuhan siswa. Berdasarkan data yang diperoleh, sebanyak 45\% siswa mengalami kejenuhan level rendah dan 55\% mengalami kejenuhan sedang.

Sebetulnya, situasi pembelajaran yang mengalami perubahan dari pembelajaran tatap muka menjadi pembelajaran virtual atau daring telah diprediksi beberap tahun yang lalu. Dalam Mustakim (2014), dijelaskan isi Buku dari Barnett Berry yang berjudul Teaching 2030 telah memprediksi kejadian yang akan dialami guru ditahun 2020-2030 an. Salah satu diantaranya adalah alat dan jaringan virtual akan membuka wilayah belajar tanpa batas bagi siswa dari segala usia, kapan saja dan dimana saja. Oleh karena 
itulah, baik siswa maupun guru perlu membiasakan halhal yang sebelumnya tidak terbiasa dilakukan dalam proses pembelajaran sebelum pandemi.

Produk kreatif dan kewirausahaan adalah salah satu mata pelajaran "pencipta pekerjaan" di lingkungan sekolah. Maka, pembelajaran produk kreatif dan kewirausahaan pada masa pandemi Covid-19 ini memerlukan inovasi untuk menciptakan mindset siswa terkait ekonomi yang keberlanjutan di tingkat nasional. Bukan hanya terbatas pada tercapainya Kompetensi Dasar siswa, namun juga harus dapat membuat mereka berpikir bahwa melalui wirausaha dapat menyediakan tempat untuk berkembang dan tumbuh secara kuat dari segi ekonomi. Di masa yang akan datang, diharapkan siswa akan dapat bekerja lebih mandiri, dan mereka harus mengambil tanggung jawab yang lebih besar untuk berhasil (Basyah, dkk, 2020).

Berikut ini beberapa hal yang tidak biasa tetapi dituntut agar terbiasa pada masa pandemi Covid-19. Yang pertama tentu saja terkait dengan proses pembelajarannya. Jika sebelumnya pembelajaran dilakukan secara langsung/ luring, maka kini pembelajaran dilakukan secara daring. Meskipun banyak kendala dan hambatan dalam prosesnya, namun mau tidak mau pembelajaran secara daring ini harus dilakukan demi jalannya proses belajar mengajar di Sekolah. Tiap minggunya, guru harus mempersiapkan bahan materi yang akan disampaikan secara daring kepada siswa, baik melalui Learning Management System (LMS) maupun aplikasi lainnya yang dapat membantu pembelajaran daring ini. Tidak hanya materi yang informatif, namun juga harus menarik agar siswa tidak bosan dengan materi yang kita sampaikan. Oleh karena itu, dalam pembelajaran daring seperti ini, guru 
dituntut lebih kreatif dalam mempersiapkan materi bahan ajarnya.

Yang kedua adalah membiasakan diri "melek IT", atau seringkali kita dengar dengan istilah tidak "gaptek" (gagap teknologi). Karena pembelajarannya berlangsung secara daring, tentu saja memanfaatkan perangkat pembelajaran yang berbasis IT, seperti laptop, PC, ataupun smartphone. Seperti yang sudah dijelaskan sebelumnya terkait perubahan jaman dan era, maka di masa pandemi ini memaksimalkan penggunaan IT. Bahkan, beberapa sekolah sudah memiliki aplikasi tersendiri dalam memfasilitasi agar proses pembelajaran antara guru dan siswa dapat berjalan secara maksimal. Jadi, bukan hanya gurunya saja yang harus menambah keahliannya dalam bidang IT, namun para siswa juga dituntut memahami bagaimana cara menggunakan laptop, PC atau smartphone mereka dalam pembelajaran di sekolah.

Dan yang terakhir adalah membiasakan siswa menjadi mandiri dengan belajar sendiri tanpa pengawasan langsung guru seperti biasanya. Guru tidak akan bisa maksimal melakukan pengawasan setiap kali pembelajaran berlangsung. Oleh karena itu, siswa perlu memiliki kesadaran dan pemahaman yang kuat bahwa mereka perlu beradaptasi dengan cara belajar mandiri dengan mengeksplor berbagai bahan ajar yang dapat diperoleh dengan mudah melalui internet. Meskipun mereka belajar mandiri, namun penugasan dan luaran dari pembelajaran produk kreatif dan kewirausahaan adalah produk hasil dari ide dan gagasan mereka sendiri. Kemudian mereka mencoba untuk memasarkan secara online, sekali lagi karena seituasi pandemi masih memaksa kita untuk memaksimalkan aktivitas secara online. 


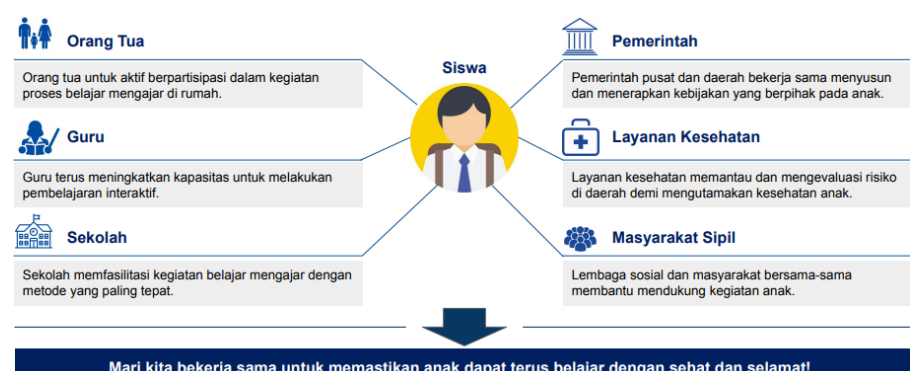

Gambar 1. Stakeholder pendukung kesuksesan belajar di masa pandemi

(Kemdikbud, 2020)

Namun perlu dipahami bahwa diperlukan kerjasama secara menyeluruh dari seluruh pihak untuk kesuksesan pembelajaran. Bukan hanya menjadi tugas guru, siswa dan orang tua. Tetapi sekolah, pemerintah, layanan kesehatan hingga masyarakat sipil mempunyai andil agar pembelajaran di masa pandemi ini bisa berjalan dengan lancar dan sesuai dengan apa yang kita semua inginkan. Mari kita membiasakan hal yang tidak biasa ini, demi mereka, generasi penerus bangsa. ${ }^{* * *}$

\section{DAFTAR PUSTAKA}

Basyah, N. A., Fahmi, I., \& Razak, A. (2020). Pendidikan Kewirausahaan Masa Covid-19: Satu Tinjauan. Jurnal Pencerahan, 14(1), 1-11.

Fauzia, E., Sulistyawati, Y., Wahyusari, D., \& Khusnah, N. (2017). Modul Produk Kreatif Dan Kewirausahaan Smk Kelas $X i$. 5. File:///C:/Users/Rtp/Downloads/Modul_Pkk_Kls _Xii_Semester_Ganjil.Pdf 
Kemdikbud. (2020). Penyesuaian Kebijakan Pembelajaran Di Masa Pandemi Covid-19. Www.Kemdikbud.Go.Id, https://Www.Kemdikbud.Go.Id/Main/Blog/2020 /08/Kemendikbud-Terbitkan-KurikulumDarurat-Pada-Satuan-Pendidikan-Dalam-KondisiKhusus

Mustakim. (2014). Kolaborasi Antara Sekolah Dengan Dunia Usaha ( Dunia Industri )Pembelajaran Kewirausahaan Melalui Kolaborasi Antara Sekolah Dengan Dunia Usaha (Dunia Industri) Pada Siswa Smk Negeri 3 Kudus Tahun 2013 Pada Siswa Smk Negeri 3 Kudus Tahun 2013. Equilibrium, 2(1), 140-156.

Rinawati, D., \& Darisman, E. K. (2020). Survei Tingkat Kejenuhan Siswa Smk Belajar Di Rumah Pada Mata Pelajaran Produk Kreatif Dan Kewirausahaan Selama Masa Pandemi Covid-19. Journal Of Science and Education, 1(1), 32-40. 


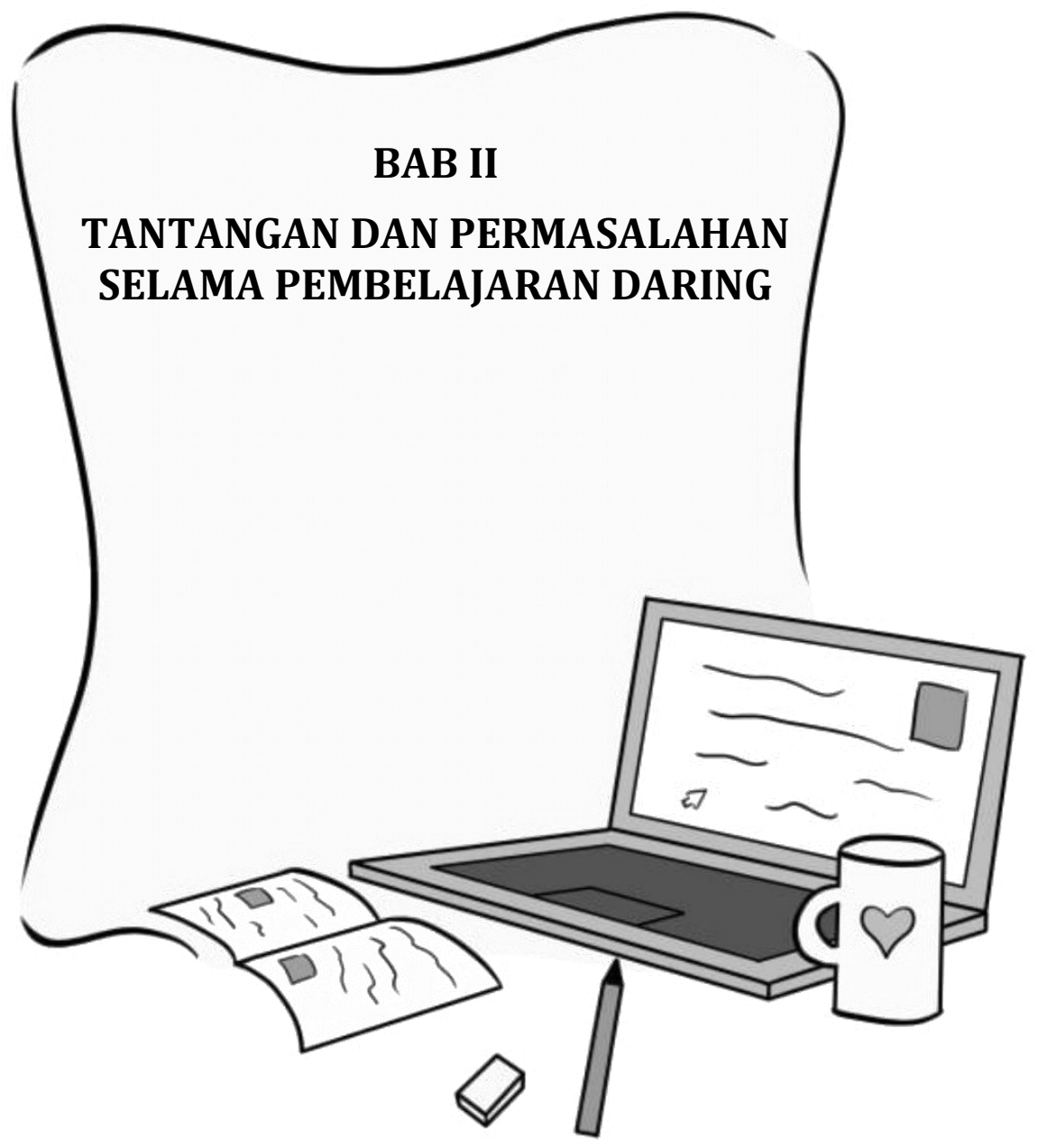

Akademisi dalam Lingkaran Daring | 79 
$\mathbf{8 0}$ | Akademisi dalam Lingkaran Daring 


\title{
APLIKASI KONSELING “MY COUNSELOR” UNTUK MENJAWAB TANTANGAN PEMBELAJARAN DARING DI MASA PANDEMI COVID-19
}

\author{
Faricha Andriani, M.Psi ${ }^{11}$ \\ (Institut Agama Islam Negeri (IAIN) Kudus)

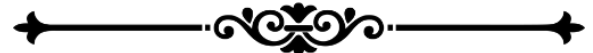

"My Counselor" merupakan aplikasi penciptaan dan pengembangan media BK berbasis teknologi yang dikembangkan mahasiswa calon guru BK di IAIN Kudus. Aplikasi ini memungkinkan pembimbingan dilakukan oleh calon guru BK meskipun tidak melalui tatap muka secara langsung.

\begin{abstract}
Corona virus diseases 2019 atau yang lebih dikenal dengan covid-19 mengukir perjalanan tersendiri dalam dinamika kehidupan manusia, tidak hanya di Indonesia melainkan di sebagian penjuru dunia. Berbagai kondisi yang ada seakan melukiskan berbagai bentuk penyesuaian dari kondisi yang disebabkan oleh virus tersebut. Tepatnya, Maret 2020, covid-19

${ }^{11}$ Penulis lahir di kota Jepara, 08 Juli 1988. Kesibukan penulis saat ini menjadi salah satu pengajar di IAIN Kudus dalam bidang ilmu psikologi. Penulis mengawali pendidikan kesarjanaannya dalam bidang keilmuan Bimbingan Konseling Islam (2006) di IAIN Kudus dan mendapatkan gelar kepascasarjanaan dalam bidang psikologi di Universitas Muhammadiyah Surakarta pada 2017.
\end{abstract}


menapakkan kakinya di Indonesia dengan menginfeksi 2 orang warga setelah melakukan perjamuan dengan warga negara asing (Nuraini, 2020). Penemuan tersebut merupakan awal dari berbagai penemuan dari beberapa kasus terkait dengan adanya bentuk penularan dan penginfeksian covid-19 hingga saat ini.

Meskipun covid-19 tidak seganas virus-virus yang sebelumnya melanda di Indonesia, seperti halnya SARS, flu burung ataupun yang lainnya. Akan tetapi, fenomena covid-19 mampu memberikan dampak pada seluruh aspek kehidupan manusia. Mulai dari kehidupan ekonomi, sosial sampai dengan pendidikan (Agung, 2020), sehingga menjadikan berbagai fenomena dalam kehidupan manusia yang tidak bisa terhindarkan. Khususnya dalam dunia pendidikan, dampak nyata dari covid-19 mendesak terjadinya transformasi metode pendidikan yang dilakukan oleh setiap warga akademik (Mansyur, 2020). Transformasi pendidikan ini tidak hanya dalam pelaksanaan kegiatan pembelajaran saja, melainkan juga dalam lingkup metode serta hal-hal yang terkait dengan pelaksanaan pendidikan kepada siswa ataupun mahasiswa yang berbasis teknologi. Misalkan dengan pemanfaatan aplikasi whatsapp, gmeet, zoom meeting dan sebagainya. Meskipun demikian, berbagai desakan akan kebutuhan pendidikan tidak hanya memberikan dampak negative saja, melainkan juga memicu timbulnya berbagai dampak positif di dunia akademisi. Salah satunya, mampu membentuk sisi kreativitas guna memenuhi kebutuhan pendidikan kapada setiap peserta didik, baik itu siswa maupun mahasiswa.

Berbagai bentuk kreativitas dalam menunjang kegiatan pendidikan, tidak hanya dikembangkan oleh para dosen dan guru saja. Akan tetapi. Berbagai desakan dari kondisi pendidikan di masa pandemic covid-19 ini, 
juga menumbuhkan kreativitas mahasiswa dalam memaksimalkan potensi yang ada dalam diri, guna memberikan sumbangsih pelaksanaan pendidikan yang lebih kreatif, inovatif serta mampu menjawab setiap kebutuhan yang berkaitan dengan pelaksanaan pendidikan yang efektif dan efisien. Berbagai desakan tersebut tidak hanya mengharuskan berbagai elemen dari pendidikan baik dosen maupun mahasiswa menemukan pembelajaran yang menarik, melainkan juga mampu memunculkan berbagai bentuk pembelajaran yang kreatif sehingga mampu mengembangkan potensi dalam diri. Seperti halnya yang dikembangkan oleh mahasiswa calon guru BK (Bimbingan Konseling) di IAIN Kudus guna menjawab berbagai tantangan akan keterbatasan media pelayanan BK di era pandemic seperti sekarang ini.

Guna mengembangkan kegiatan praktik pelayanan BK ditengah keterbatasan interaksi sosial, maka para mahasiswa BK mampu mengembangkan aplikasi yang mampu mewakili setiap mahasiswa calon guru BK dalam pelaksanaan praktik pelayanan BK. Bentuk aplikasi ini sebagai bagian dari kegiatan mata kuliah praktik yang mengharuskan setiap mahasiswa, mampu mengembangkan berbagai media BK yang menarik serta mampu memberikan bentuk pelayanan yang maksimal dalam keterbatasan interaksi sosial seperti kondisi sekarang ini. Bentuk penciptaan dan pengembangan media BK berbasis teknologi yang dikembangkan mahasiswa calon guru BK di IAIN Kudus ini biasa dikenal dengan sebuatan "My Counselor". Melalui media ini, kegiatan praktik pelayanan BK yang dilakukan oleh calon guru BK mampu dilaksanakan meskipun tanpa melakukan tatap muka secara langsung. Hal tersebut dikarenakan, melalui aplikasi ini, setiap calon guru BK mampu memberikan pelayanan kepada para konselinya 
atau peserta didik melalui sistem daring dengan memanfaatkan fitur chatting.

Penggunaan media pelayanan BK dalam "My Counselor" pun bisa di katakana cukup mudah untuk para guru dan siswa nantinya. Hal itu dikarenakan, aplikasi ini menggunakan fitur private chatting dalam pelaksanaan pelayanan kepada konseli. Selain itu juga, berbagai informasi yang berkaitan dengan perkembangan siswa juga disediakan dalam aplikasi tersebut, sebagai bentuk dari pelayanan informasi kepada konseli atau peserta didik nantinya. Tidak hanya bentuk layanan bimbingan dan konseling individu ataupun pelayanan informasi saja, melainkan juga, dalam aplikasi tersebut juga dikembangkan pula kegiatan yang memberikan bentuk kenyamanan konseli nantinya. Hal tersebut dikarenakan setiap konseli, bebas menentukan siapakah konselor (calon guru BK) yang nantinya akan memberikan pelayanan yang di inginkan oleh konselinya (peserta didik).

Sehingga, bisa dikatakan bahwa penciptaan dan pengembangan aplikasi "My Counselor" mampu memberikan jawaban atas kegaluan setiap guru BK dalam memberikan pelayanan kegiatan BK secara maksimal yang di peruntukkan untuk peserta didik khusunya dan untuk khalayak ramai pada umumnya. Sehingga, tidak hanya mampu digunakan sebagai produk dari media BK dari kegiatan praktik pelayanan BK yang dilakukan oleh para mahasiswa calon guru BK saja, melainkan juga oleh para guru BK secara umum nantinya. Jika dipandang lebih jauh, maka kegiatan penciptaan dan pengembangan aplikasi "My Counselor" merupakan bentuk lain yang dikembangkan yang tercipta dari berbagai bentuk keterbatasan. Tidak hanya keterbatasan dalam lingkup sosial dengan berbagai Batasan dalam melakukan berbagai interaksi sosial. 
Melainkan juga dalam lingkup dalam mensukseskan kegiatan pembelajaran jarak jauh sesuai dengan kebijakan pemerintah. Yang mana, sebagai jawaban dari berbagai tantangan yang ditawarkan oleh dunia pendidikan di masa pandemic covid-19, yang mengharuskan terciptanya berbagai inovasi yang mampu efektif dan efisien sesuai dengan kebutuhan pendidikan pada kondisi seperti sekarang ini.

Sehingga, penggunaan "My Counselor" sebagai praktik mikro pelayanan BK yang dikembangkan oleh para calon guru BK ini, mampu memberikan alternative solusi yang menekankan pada pemaksimalan bentuk aplikasi pelayanan BK secara maksimal dan tetap menjalankan kebijakan pemerintah dengan pembatasan pembelajaran melalui tatap muka secara langsung.

\section{DAFTAR PUSTAKA}

Agung, I. M. (2020). Memahami Pandemi COVID-19 dalam Perspektif Psikologi Sosial. Psikobuletin: Buletin Ilmiah Psikologi, 1(2), 68-84. https://doi.org/10.24014/pib.v1i2.9616

Mansyur, A. R. (2020). Dampak COVID-19 Terhadap Dinamika Pembelajaran Di Indonesia. Education and Learning Journal, 1(2), 113-123.

Nuraini, T. N. (2020). Kronologi Munculnya Covid-19 di Indonesia hingga Terbit Keppres Darurat Kesehatan. Merdeka.Com. 
86 | Akademisi dalam Lingkaran Daring 


\section{MENGAJAR AKUNTANSI DI ERA NEW NORMAL}

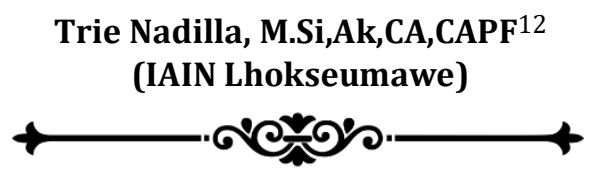

"Meskipun internet memberikan peluang yang sangat besar untuk lingkungan pembelajaran alternatif berbasis web, namun infrastruktur teknologi dan kapasitas digital dan mental para akademisi dan mahasiswa harus dipersiapkan dan didukung secara efektif.

Dandemi Covid-19 kenyataan yang harus diterima dengan kelapangan hati. Tetap berprasangka baik pada ketetapan Allah. Terlepas informasi yang beredar Covid 19 yang sudah memasuki tahun ke - 3 ini sebagian menyebutkan bagian dari konspirasi yang telah menelan korban 1.718.575 jiwa (dilansir www.okezone.com) namun atas izin-Nya covid itu masih ada hingga saat ini. Jika Allah pencipta alam

12 Penulis lahir di Banda Aceh, 19 Maret 1989, penulis merupakan Dosen IAIN lhokseumawe, bidang program studi, penulis menyelesaikan gelar Sarjana Ekonomi di Universitas Syiah Kuala (2010), sedangkan gelar Magister Akuntansi dan Program Pendidikan Profesi Akuntansi diselesaikan di universitas yang sama (2016). Selanjutnya menempuh pendidikan non formal Certified Analyst in Project Finance (CAPF) yang diselenggarakan oleh Academy of Finance and Management Australia (2020) dan program akuntan chartered accountant (2021) yang diselenggarakan oleh Ikatan Akuntan Indonesia. 
semesta ini berkehendak maka tidak ada seorang pun dapat menolaknya. Allah berfirman dalam At-Taubah ayat 51: "Katakanlah (Muhammad), "Tidak akan menimpa kami melainkan apa yang telah ditetapkan Allah bagi kami. Dialah pelindung kami, dan hanya kepada Allah bertawakallah orang - orang yang beriman". Pandemi Covid - 19 menimbulkan pengaruh signifikan terhadap perubahan tatanan masyarakat, regulasi pemerintah termasuk perubahan sistem pembelajaran.

Kebijakan social distancing dan physical distancing yang instruksikan oleh pemerintah bertujuan untuk meminimalisir mitigasi penyebaran COVID-19. Salah satunya dalam proses belajar mengajar dilakukan penutupan aktivitas kegiatan belajar di ruangan selama waktu yang belum ditentukan. Maka dari itu, untuk mengatasi hal tersebut, pihak universitas memberlakukan pembelajaran di lakukan secara daring dengan memanfaatkan fasilitas teknologi penunjang yang mendukung. Pembelajaran daring merupakan pengalaman transfer pengetahuan menggunakan video, audio, gambar, komunikasi teks, perangkat lunak dengan menggunakan jaringan internet (Zhu \& Liu, 2020).

Kondisi tersebut menuntun tenaga pengajar untuk melakukan inovasi dan adaptasi dalam menggunakan teknologi untuk menunjang proses belajar mengajar. Adapun platform pembelajaran yang biasa digunakan berupa aplikasi zoom, Goole Meet, kahoot, google classroom. Selanjutnya, media sosial antara lain instagram, facebook, tik tok, whatssap, you tube maupun learning management system. Berbagai platform diatas dapat digunakan dalam mentransfer bahan ajar yang didukung dengan diskusi kelompok dan lain sebagainya. Adapun yang menjadi kelemahan dalam mengajar 
secara daring yakni jaringan yang tidak stabil bahkan ada mahasiswa yang tidak memiliki jaringan sama sekali di daerah tempat tinggalnya. Selain itu, paket internet yang terkadang semua mahasiswa tidak berasal dari keluarga ekonomi yang cukup. Kompetensi tenaga pendidik dalam belajar secara daring sangat mempengaruhi. Tidak ada hanya menguasai bahan ajar, namun juga mumpuni dalam menggunakan teknologi.

Pembelajaran online menuntut peran pendidik mengevaluasi efektivitas dan disesuaikan dengan kebutuhan belajar dan kondisi mahasiswa. Ini penting dilakukan untuk tetap memenuhi aspek pembelajaran seperti proses pengetahuan, moral, keterampilan, kecerdasan dan estetika (Siregar, 2020). Maka dari itu, diperlukan strategi pembelajaran yang efektif untuk meningkatkan perilaku belajar peserta didik. Strategi pembelajaran merupakan perencanaan, metode, atau rancangan kegiatan pembelajaran dengan pemanfaatan berbagai sumber daya untuk mencapai tujuan pendidikan tertentu. Proses belajar mengajar akuntansi membutuhkan rencana dan strategi yang tepat sehingga tujuan pembelajaran yang kompleks dapat tercapai. David dalam Sanjaya (2006). Adapun pendekatan dalam strategi pembelajaran antara lain Blended learning, fully online, or virtual classroom. Semenjak Covid 19 melanda, maka sistem ajar face to face, blended learning beralih ke fully online model.

Akuntansi merupakan ilmu pengetahuan terapan dan seni pencatatan yang membutuhkan pratikum. Seni pencatatan akuntansi memiliki sistem tertentu, mengolah dan menganalisis catatan sehingga dapat disusun suatu laporan keuangan sebagai bentuk pertanggungjawaban terhadap user. Mata kuliah di program studi akuntansi terdiri dari Pengantar Akuntansi, Akuntansi Manajemen, Akuntansi Biaya, 
Akuntansi Keuangan Menengah, Akuntansi Keuangan Lanjutan. Mahasiswa selain perlu memahami konsepteoritis juga dituntut untuk terampil dalam melakukan penghitungan, penjurnalan serta mencari solusi dalam kasus yang ada.

Platform ideal yang digunakan zoom atau google meet, mengingat mata kuliah akuntansi membutuhkan face to face untuk diskusi. Namun, dalam prakteknya terkendala jaringan. Tidak semua, tempat tinggal mahasiswa memiliki sinyal jaringan yang memadai dan paket internet yang tidak cukup kuota. Ini menjadi tantangan sebagai pengajar. Untuk mengantisipasi hal tersebut supaya materi ajar tersampaikan. Maka, langkah yang diambil dengan menggunakan media membuat video dengan menggunakan platform bandicam, kine master lalu kirim via youtube. Selanjutnya, untuk kegiatan diskusi materi menggunakan whatssap. Kelemahan whatssap selain memenuhi memori, juga tidak cepat dalam merespon pertanyaan. Setidaknya strategi pembelajaran ini termasuk efektif di tengah kondisi covid seperti ini.

Perubahan drastis kondisi saat ini, membuat para pendidik memiliki waktu yang terbatas dituntut untuk bisa langsung beradaptasi dengan teknologi untuk menyiapkan materi secara daring. Di sisi lain, para peserta didik juga memiliki waktu yang singkat untuk menggunakan platform pembelajaran online. Kondisi ini menyebabkan peningkatan tekanan psikologis di antara pendidik sehingga berpengaruh terhadap kinerja perkuliahan dan kapasitas siswa dalam menyerap ilmu ( Besser, Lotem and Zeigler-Hill, 2020). Proses belajar di era new normal yang dilakukan secara daring menunjukkan bahwa meskipun internet memberikan peluang yang sangat besar untuk lingkungan pembelajaran alternatif berbasis web, namun 
infrastruktur teknologi dan kapasitas digital dan mental para akademisi dan mahasiswa, harus dipersiapkan dan didukung secara efektif.

\section{DAFTAR PUSTAKA}

Besser, A., Lotem, S., \& Zeigler-Hill, V. (2020). Psychological stress and vocal symptoms among university professors in Israel: implications of the shift to online synchronous teaching during the COVID-19 pandemic. Journal of Voice.

Djajadikerta, H. G., Trireksani, T., Ong, T., Roni, S. M., Kazemian, S., Zhang, J., ... \& Wahyuningrum, I. F. S. (2021). Australian, Malaysian and Indonesian Accounting Academics' Teaching Experiences During the COVID-19 Pandemic. Australasian Accounting, Business and Finance Journal, 15(2), 103-113.

Fadhilah, G. A. (2020). Peran Lingkungan Belajar dalam Menyikapi Pembelajaran Daring di Era Covid19. Jurnal Ilmiah Fakultas Keguruan Dan Ilmu Pendidikan, 6(2), 106-116. https:// doi.org/10.35569

Latifah, L., \& Susilowati, N. (2011). Inovasi Pembelajaran Akuntansi Berbasis Blended Learning. Dinamika Pendidikan, 6(2), 222-232.

Prasetio, T., \& Hariyani, R. (2021). Persepsi Mahasiswa Terhadap Pembelajaran Daring Pada Mata Kuliah Akuntansi Di Era New Normal. Jurnal Perspektif, 19(1), 57-63.

Siregar, M. Y., \& Akbar, S. A. (2020). Strategi guru dalam meningkatkan kualitas mengajar selama masa Pandemi COVID-19. At-Tarbawi, 12(2), 180-188. 
Zhu, X., \& Liu, J. (2020). Education in and after Covid-19: Immediate responses and long-term visions. Postdigital Science and Education,2(3), 695-699. 


\title{
PELUANG DAN TANTANGAN PEMBELAJARAN DARING MASA PANDEMI COVID-19
}

\author{
Mochammad Ronaldy Aji Saputra, S.Pd ${ }^{13}$ \\ (MAN Sumenep)

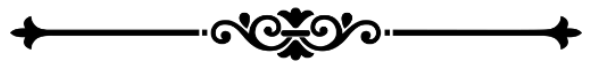

"Pendidik harus terampil dalam mengoperasikan

platform-platform pembelajaran, guru wajib mengembangkan metode pembelajaran yang sesuai gaya belajar dan keterampilan siswanya secara online, dan perlunya pembiasaan/adaptasi."

Dada tahun akhir tahun 2019 telah muncul sebuah Pvirus di Wuhan Cina bernama Covid-19. Virus Covid-19 kemudian menyebar ke seluruh dunia hingga mengalami peningkatan sehingga WHO telah mengumumkan status sebagai pandemi global. Status pandemi global memberikan dampak bagi negara Indonesia sehingga tanggal 16 Maret 2020 pemerintah mengambil kebijakan kepada seluruh masyarakat untuk bekerja dari rumah. Anjuran bekerja dari rumah atau work from home mengakibatkan manusia menggunakan teknologi digital. Penggunaan teknologi digital

${ }^{13}$ Penulis lahir di Sidoarjo, 14 Januari 1995, penulis merupakan Guru Sejarah MAN Sumenep. Penulis menyelesaikan gelar Sarjana Pendidikan Sejarah di Universitas Negeri Malang (2017). 
bertujuan untuk memutus penularan Covid-19. Penggunaan teknologi digital secara masif di dunia memunculkan era peradaban baru yang dikenal dengan digital civilization atau peradaban digital. Penggunaan teknologi digital secara masif memberikan perubahan dari berbagai bidang. Dalam bidang pendidikan telah mengalami peningkatan yang signifikan pada masa pandemi Covid-19. Di Indonesia mulai mengalami peningkatan sejak diberlakukan BDR (Belajar Dari Rumah) yang dilakukan secara daring (dalam jaringan) dengan teknologi digital. Peningkatan ini telah memberikan sebuah peluang dan tantangan bagi guru dan siswa.

\section{Peluang yang dihadapi oleh Guru dan Siswa dalam Pembelajaran Daring}

Pembelajaran daring dilakukan dengan teknologi digital telah memberikan nuansa baru. Hal ini menjadikan sebuah peluang bagi guru untuk memanfaatkannya. Wisacita (2020) kegiatan pembelajaran daring memberikan peluang bagi guru dan peserta didik untuk memanfaatkan teknologi dan lebih mudah mengatur waktu dalam proses pembelajaran. Dengan tersusunnya pembelajaran dengan sistem daring, maka guru bisa mengawasinya dengan secara jarak jauh tanpa tatap muka.

Covid-19 justru dampak luar biasa terhadap transformasi digital menuju era pendidikan 4.0. Jika sebelumnya terdapat wacana, kebijakan dan sosialisasi terkait revolusi industri 4.0 maka dengan adanya Covid19 justru memberikan progress signifikan pada transformasi digital pendidikan Indonesia. Pemicu percepatan proses transformasi digital pendidikan Indonesia menurut Astini (2020) karena kegiatan pembelajaran daring memberikan kesempatan bagi lembaga pendidikan untuk melek teknologi dan dengan 
pemberlakukan perkuliahan online. Pandemi Covid-19 juga memiliki terobosan baru dalam mengembangkan nilai-nilai karakter peserta didik dalam pembelajaran daring. Terobosan tersebut menurut Absor (2020) berfokus kepada ranah afektif yang dapat diinternalisasikan ke dalam kehidupan sehari-hari peserta didik/mahasiswa secara tersirat atau disebut juga sebagai hidden curriculum (kurikulum tersembunyi). Hal ini guru/dosen juga harus sadar bahwa dalam penanaman nilai-nilai karakter dalam pembelajaran daring memang rumit karena tidak dilakukan secara tatap muka.

\section{Tantangan yang dihadapi oleh Guru dan Siswa dalam Pembelajaran Daring}

Pembelajaran dalam jaringan merupakan kegiatan pembelajaran yang dilakukan secara jarak jauh melalui jaringan internet dengan berbantuan teknologi digital. Beberapa ciri-ciri dari pembelajaran daring menurut Flinders University (dalam Saputra, 2021: 107), yaitu personal, structured, active dan connective. Personal merupakan pengalaman belajar yang diciptakan oleh siswa atas pijakan sendiri. Dalam pembelajaran ini siswa dapat menciptakan suasana belajar yang nyaman dan sesuai dengan keinginan. Structured berarti dalam pembelajaran guru terlebih dahulu menyiapkan silabus, materi pelajaran, media dan sumber belajar sehingga kegiatan dapat dilakukan secara terstruktur. Active yaitu guru dan siswa aktif dalam proses pembelajaran melalui teknologi. Connective berarti terdapat hubungan guru dan siswa dalam proses pembelajaran yang tidak ada batasan ruang dan waktu.

Kegiatan pembelajaran daring juga membutuhkan teknologi digital agar mendukung jalannya pembelajaran. Pelbagai platform yang telah digunakan oleh guru antara lain e-learning, LMS (Learning 
Management System), whatsapp, zoom meeting, jitsi meeting, google classroom, dsb. Platform tersebut memiliki fungsi masing-masing sehingga guru menggunakannya secara kombinasi. Hal ini juga seperti yang dilakukan oleh Saputra (2020) yaitu mengombinasikan antara whatsapp dan e-learning madrasah dengan hasil yang cukup efektif.

Pembelajaran daring membutuhkan platform baik perangkat keras maupun perangkat lunak. Masoud \& Bohra (2020) menyebutkan beberapa langkah agar platform pembelajaran daring efektif untuk dipelajari oleh institusi akademik, antara lain (a) konferensi video dengan setidaknya 40 hingga 50 siswa dimungkinkan, (b) diskusi dengan siswa dapat dilakukan untuk menjaga kelas tetap organik, (c) koneksi internet bagus dan cepat, (d) perkuliahan juga dapat diakses melalui telepon genggam dan bukan hanya laptop, (e) kemungkinan menonton perkuliahan yang sudah direkam, dan (f) instan umpan balik dari siswa dapat dicapai dan tugas dapat diambil. Keseluruhan langkah tersebut dapat dilakukan dengan mengintegrasikan antara platform dan kondisi siswa yang heterogen. Perubahan kegiatan pembelajaran dari tatap muka ke daring menyebabkan sebuah tantangan bagi guru dan siswa. Tantangan ini membuat guru melakukan inovasi pembelajaran baru untuk mencapai target keberhasilan. Salsabila, Sari, Lathif \& Lestari (2020) keberhasilan pembelajaran daring tidak hanya dipengaruhi dari peran teknologi saja, tetapi juga dipengaruhi dari kualitas Sumber Daya Manusia. Teknologi tidak akan memiliki fungsi apabila SDM (Guru dan Siswa) sebagai operator atau pengguna tidak memiliki pengetahuan serta keterampilan yang baik dalam penggunaan dan pengelolaan teknologi. 
Pembelajaran daring juga harus bersifat fleksibel, yaitu guru memahami peserta didiknya dan peserta didik harus siap menerima pelajaran. Gilbert (2015) kursus online menawarkan cara terbaik bagi siswa untuk memperluas pendidikan apabila siswa memiliki motivasi diri, pembelajar mandiri, dan bertanggung jawab kemudian instruktur (guru) memahami gaya belajar dan keterampilan seseorang akan memungkinkan siswa untuk lebih akurat menentukan apakah pembelajaran online cocok untuk mereka. Pembelajaran daring akan terhambat juga apabila siswa tersebut memiliki motivasi, kemandirian, rasa tanggung jawab yang rendah. Dengan demikian guru wajib memahami siswanya dan memiliki metode pembelajaran yang sesuai gaya belajar dan keterampilan siswanya.

Tantangan kemandirian siswa terletak pada bagaimana siswa beradaptasi secara langsung dalam pembelajaran daring. Hal ini perlu diadakan pendampingan secara jarak jauh oleh guru. Pandampingan tersebut menurut Enbuskaa, Rimppia, Hietanena, Tuiskua, Ruokonenb \& Ruismäkib (2018) dapat dilakukan dengan menginstrusikan terlebih dahulu kepada siswa tentang manfaat dan cara menggunakan platform e-learning dan pembelajaran campuran untuk menyempurnakannya pengetahuan dan keterampilan melalui pembelajaran mandiri. Melakukan instruksi secara online memang suatu hal yang baru dan membutuhkan adaptasi sehingga menjadi tantangan bagi guru untuk mengajarkan kepada siswanya.

\section{Kesimpulan}

Pandemi Covid-19 dalam dunia pendidikan telah memberikan sebuah terobosan-terobosan baru yang menjadikan sebuah peluang. Akan tetapi peluang- 
peluang tersebut juga terdapat tantangan bagi guru untuk mengembangkan desain pembelajaran khususnya pembelajaran daring yang memiliki ciri personal, structured, active dan connective.

Peluang-peluang dengan adanya pandemi Covid-19 menjadikan guru memanfaatkan teknologi dan lebih mudah mengatur waktu dalam proses pembelajaran, memberikan terobosan baru dalam mengembangkan nilai-nilai karakter dengan secara tersirat atau disebut kurikulum tersembunyi (hiden curiculum), dan sekaligus mendorong untuk mempercepat transformasi digital menuju era pendidikan 4.0. Namun, dari semua peluang tersebut terdapat tantangan yang dihadapi oleh guru dan siswa, yaitu harus terampil dalam mengoperasikan platform-platform pembelajaran, guru wajib mengembangkan metode pembelajaran yang sesuai gaya belajar dan keterampilan siswanya secara online, dan perlunya pembiasaan/adaptasi. $* * *$

\section{DAFTAR PUSTAKA}

Absor, N.F. 2020. Pembelajaran Sejarah Abad 21: Tantangan dan Peluang dalam Menghadapi Pandemi Covid-19. Chronologia: Journal of History Education. 2(1): 30-35.

Astini, N.K.S. 2020. Tantangan Dan Peluang Pemanfaatan Teknologi Informasi Dalam Pembelajaran Online Masa Covid-19. Ceta: Jurnal Ilmu Pendidikan. 3(2): 241-255.

Enbuskaa, J., Rimppia, A., Hietanena, L., Tuiskua, V., Ruokonenb, I \& Ruismäkib, H. 2018. E-learning Environments, Opportunities and Challenges in Teaching and Learning to Play the Piano in Student Teacher Education. The European Journal 
of Social and Behavioural Sciences. 21(1): 25622569.

Gilbert, B. 2015. Online Learning Revealing the Benefits and Challenges. New York: School of Education St. John Fisher College.

Masoud \& Bohra. 2020. Challenges And Opportunities Of Distance Learning During Covid-19 In UAE. Academy of Accounting and Financial Studies Journal. 24(5): 1-12.

Salsabila, U.H., Sari, L.I., Lathif, K.H \& Lestari, A.P. 2020. Peran Teknologi Dalam Pembelajaran di Masa Pandemi Covid-19. Al-Mutharahah: Jurnal Penelitian dan Kajian Sosial Keagamaan. 7(2):188-198.

Saputra, M.R.A. 2020. "Efektivitas Pembelajaran Sejarah Berbasis Daring Masa Pandemi Covid-19". Artikel disajikan di Simposium Nasional Pengajaran Sejarah ke II Asosisasi Guru Sejarah Indonesia. Surabaya, 12 Desember 2020.

. 2021. Tantangan, Jawaban dan Harapan dalam Pembelajaran Daring Masa Pandemi Covid19. Karanganyar: Penerbit Yayasan Lembaga Gumun Indonesia.

Wisacita, M. 2020. Tantangan Dan Peluang Proses Pembelajaran Biologi Di SMA Negeri 1 Polanharjo Klaten Dalam Masa dan Pasca Pandemi Covid-19. Artikel disajikan di Seminar Nasional Pascasarjana Universitas Negeri Semarang. 
100 | Akademisi dalam Lingkaran Daring 


\title{
TANTANGAN PERAN GURU DALAM E- LEARNING: MANDIRI BELAJAR DI MASA PANDEMI COVID-19
}

\author{
Dwi Martiningsih, S.Psi, M.A. ${ }^{14}$ \\ (Lajnah Pentahsihan Mushaf Al-Qur'an (LPMQ) \\ Kementerian Agama RI)

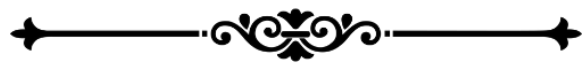

"E-learning merupakan salah satu model pembelajaran

yang cocok digunakan di masa pandemi Covid-19.

Perubahan ruang kelas fisik ke dalam ruang kelas yang sifatnya virtual menjadi tantangan tersendiri bagi guru selaku tenaga pengajar."

Derkembangan zaman menjadikan tehnologi semakin pesat berkembang, tak terkecuali di dunia
pembelajaran. Dengan tehnologi manusia dapat belajar secara elektronik (tanpa bertatap muka secara langsung). Apalagi di masa pandemi Covid-19 yang belum kita ketahui secara pasti kapan berakhirnya, $e$ -

\footnotetext{
${ }^{14}$ Penulis lahir di Purworejo, 27 Maret 1984. Saat ini penulis aktif sebagai seorang Peneliti di Lajnah Pentahsihan Mushaf Al-Qur'an, Badan Litbang dan Diklat Kementerian Agama RI. Penulis menyelesaikan S1 di jurusan Psikologi Universitas Diponegoro Semarang, sedangkan S2 di Pengkajian Islam UIN Syarif Hidyatullah Jakarta. Pada tahun 2018-2020 penulis juga menjadi tim penilai Buku Ajar Pendidikan Agama Islam di Puslitbang Lektur dan Khasanah Keagamaan, Badan Litbang dan Diklat Kementerian Agama RI.
} 
learning menjadi suatu solusi bagi dunia pendidikan. Presiden Jokowi di awal pandemi Covid-19 (Maret 2020) menyarankan agar siswa belajar melalui aplikasi pembelajaran daring atau online sehingga proses belajar mengajar dapat tetap berjalan dengan baik (Candra dalam Republika Senin, 16 Maret 2020). Elearning (electronic learning) merupakan proses pembelajaran secara online dengan memanfaatkan tehnologi (Chandrawati, 2010:101-103).

Metode e-learning bukan hal yang baru di dunia pendidikan, karena sudah ada sejak tahun1970-an (Brown dalam Wena, 2009). E-learning lebih mengarah pada kelas virtual. Materi pembelajaran dapat disampaikan dengan berbagai sarana: internet, intranet, video, audio, youtube streaming, zoom, google meet dan sebagainya. Islami dan Harimurti menyimpulkan prestasi belajar siswa meningkat setelah memanfaatkan media pembelajaran e-learning pada konten "Eduvidgame" (Islami dan Harimurti, 2016:137). Hasil penelitian Rusman juga menegaskan model pembelajaran e-learning sebagai model pembelajaran berbasis web dapat meningkatkan hasil belajar mahasiswa pada mata kuliah kurikulum dan pembelajaran (2016:1-15).

\section{MODEL E-LEARNING}

Menurut Haughey dan Anderson (1998) model pembelajaran e-learning ada tiga macam: model tradisional plus atau adjuct learning, blended learning dan full online learning. Adjuct learning merupakan sistem pembelajaran tatap muka di dalam kelas, media elektronik hanya sebagai penunjang pembelajaran. Blended learning merupakan model pembelajaran dengan memadukan sistem tatap muka dengan daring (dalam jaringan). Full online learning adalah model 
pembelajaran dalam jaringan secara penuh atau biasa disebut dengan distance learning.

E-learning, dari sisi interaksi guru dan siswa ada dua jenis: synchronous dan asynchronous. Metode synchronous merupakan metode belajar di mana guru dan siswa bertemu bersama secara online. Fasilitas dalam metode synchronous dapat berupa video conference, live streaming, youtube streaming, zoom meeting, google meet, microsoft team, maupun lainnya. Sedangkan metode asynchronous adalah metode pembelajaran dalam jaringan yang tidak mempertemukan guru dan siswa di saat yang bersamaan. Metode asynchronous cenderung ke pemberian penugasan yang kreatif dan inovatif. Misalnya: video pembelajaran, website, mailing list, news letter dan lainnya (Narayana, 2016:139-143).

\section{KEUNGGULAN E-LEARNING}

Ada banyak platform e-learning, contohnya: Ruang Guru, Quipper School, Moodle (memadu e-learning dengan jejaring sosial) maupun aplikasi lainnya. Ruang kelas berbasis web menjadi tempat guru dalam mengelola materi ajar, memberi tugas dan menilainya, hingga memonitor perkembangan belajar siswa secara langsung.

Beberapa keunggulan e-learning menurut Rusman: sangat dinamis, fleksibel, bersifat individual, dan komprehensif. Dinamis karena dapat disajikan dalam berbagai format yang menarik dan interaktif. Fleksibel dari sisi operasional waktu sehingga baik guru maupun siswa dapat memperoleh dan membagikan informasi kapanpun saat memerlukan. Bersifat individual sehingga siswa dapat memilih model pembelajaran yang relevan dengan latarbelakang dan gaya belajarnya masing-masing. Bisa saja antara satu individu dengan 
materi yang sama tetapi gaya belajarnya berbeda sehingga bahan belajar dapat berbeda. Bersifat komprehenshif karena menyediakan berbagai bentuk proses pembelajaran dari berbagai sumber sebagai sumber belajar dan latihan (Rusman, 2016: 1-15).

Beberapa kelebihan e-learning lainnya di antaranya: materi pelajaran dapat diunduh secara langsung di gadget (tidak harus membeli buku cetak), fleksibilitas belajar secara mandiri (kapan belajar, dan materi atau pelajaran apa yang ingin dipelajari lebih dahulu), dapat dijadwalkan kelas secara daring via zoom untuk interaksi guru dan siswa sehingga menunjang pemahaman peserta didik.

E-learning selain memiliki keunggulan, di sisi lain memiliki tantangan tersendiri, khususnya terkait kesiapan guru dan siswa. Diantaranya: ada tuntutan kemandirian siswa untuk sadar belajar, kemampuan manajerial guru sesuai platform yang digunakan dalam penyiapan materi (video tutorial, audio recorder, podcast, ebook atau modul); penyampaian materi (google meet, zoom meting, youtube streaming, website) hingga evaluasi pembelajaran (penugasan, diskusi di forum). Penguasaan tehnologi baik guru maupun siswa menjadi suatu hal yang wajib dikuasai dalam e-learning. Hal lain yang tidak kalah penting adalah ketersediaan sarana prasarana pembelajaran (ebook, kuota internet, laptop/komputer atau HP yang mendukung pembelajaran, dan tersedianya jaringan).

\section{TANTANGAN PERAN GURU DALAM E-LEARNING}

E-learning membawa tantangan tersendiri bagi para guru, khususnya bagaimana menggunakan tehnologi sebagai media pembelajaran. Karakteristik utama $e$ learning bersifat independent. Daya tangkap siswa tidak bergantung pada kemampuan guru dalam 
menyampaikan materi belajar. Tugas berat guru adalah bagaimana menjaga mutu pembelajaran, agar siswa mampu mengakses sumber-sumber pembelajaran yang valid, belajar secara lebih mandiri sehingga mampu menguasainya dengan baik.

Menurut Hendrastomo masih banyak pengajar yang sekedar tahu, mengikuti pelatihan satu dua kali, namun menganggap mampu dan paham tentang metode pembelajaran. Hal tersebut berefek pada proses pembelajaran yang tidak bisa maksimal karena kurangnya pengetahuan dan kemahiran dalam menguasai metode pembelajaran. Penguasaan teknologi mutlak diperlukan oleh individu yang akan menerapkan pembelajaran e-learning, baik guru maupun siswa. Tanpa penguasaan teknologi (terutama komputer dan internet), pembelajaran menjadi tidak efektif (Hendrastomo, 2008: 1-14).

Banyak sekali sumber belajar yang tersedia secara online; modul/buku, tutorial praktik video, audio, seminar, talkshow, hingga focus group discussion. Siswa dapat diberi pengayaan dan kesempatan untuk belajar sesuai dengan karakternya: visual, audio, atau kinestetik.Tugas guru lebih ke manajerial atau mengelola kelas agar tujuan pembelajaran dapat tercapai dengan baik sesuai dengan kurikulum. Hal ini membutuhkan kreativitas, inovasi dan adaptasi guru agar siswa tidak bosan dan termotivasi untuk belajar dengan mandiri.

\section{PENUTUP}

Implementasi e-learning ditinjau dari sisi SDM (Sumber Daya Manusia) berfokus pada dua aktor. Pertama, guru sebagai aktor utama pengerak pembelajaran e-learning. Kedua, tentu saja siswa yang senantiasa selalu diharuskan mengikuti perkembangan 
pembelajaran yang diterapkan oleh pengajar. Peran guru sebagai penggerak utama harus didukung dengan berbagai kompetensi. Selain kompetensi manajerial, pedagogis, yang tidak kalah penting adalah penguasaan teknologi karena berkaitan dengan pembelajaran $e$ learning.

\section{DAFTAR PUSTAKA}

Chandrawati, Sri Rahayu. (2010). Pemanfaatan ELearning dalam Pembelajaran. Jurnal Cakrawala Kependidikan. Vol 8 Nomor 2 September 2010: 101-203.

Grendi Hendrastomo, Dilema dan Tantangan E-learning. Majalah Ilmiah Pembelajaran, Volume 4 Nomor 1, Mei 2008. No ISSN: 0216-7999.

Haughey, M. dan Anderson, T. 1998. Networking Learning: The Pedagogy of the Internet. Montreal: Cheneliere/ McGraw-Hill.

I Wayan Gede Narayana. Analisis Terhadap Hasil Penggunaan Metode Pembelajaran Synchronous dan Asynchronous, Seminar Nasional Teknologi Informasi Dan Multimedia 2016 Stmik Amikom Yogyakarta, 6-7 Februari 2016.

Lu'Lu' Dien Islami dan Rina Harimurti. Pemanfaatan Media Pembelajaran E-learning Pada Konten "Eduvidgame" Untuk Meningkatkan Hasil Belajar Siswa Smk Kelas x Pada Mata Pelajaran Perakitan Komputer. Jurnal IT-Edu Volume 01 Nomor 01 Tahun 2016, 137-142.

Rusman, Pengembangan Model E-learning untuk Meningkatkan Hasil Belajar Mahasiswa, Kwangsan, Vol. 4 No. 1, Edisi Juni 2016. 
Sapto Andika Candra. Jokowi Arahkan Murid Belajar Lewat Aplikasi Daring, Republika 16 Maret 2020, https://www.republika.co.id/berita/q7a69s396/ jokowi-arahkan-murid-belajar-lewat-aplikasidaring akses pada 8 Mei 2021.

Wena, Made. (2009). Strategi Pembelajaran Inovatif Kontemporer. Jakarta: Bumi Aksara. 
108 | Akademisi dalam Lingkaran Daring 


\section{WABAH COVID-19 MEMBERIKAN ANCAMAN MENJADI SEBUAH PELUANG DALAM PARADIGMA PENDIDIKAN 4.0: SOLUSI PEMBELAJARAN JARAK JAUH}

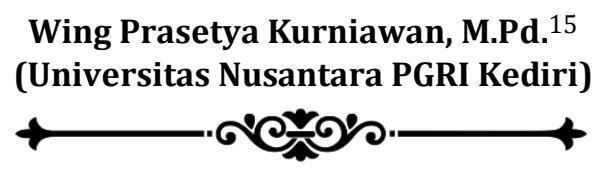

"Pembelajaran jarak jauh dalam paradigma pendidikan 4.0 ini menjadi hal penting bagi pendidik, siswa, maupun orangtua, apalagi ditambah dengan situasi wabah Covid19. Penguasaan teknologi pendukung pembelajaran dan strategi penggunaannya dalam pembelajaran daring menjadi tantangan tersendiri."

S ituasi wabah covid-19 yang memberikan pengaruh yang sangat besar bagi kehidupan manusia misalnya akan membunuh ekonomi secara global, banyak pekerja yang di PHK kemudian dalam kehidupan sehari-hari dimana saat ini kebutuhan pengeluaran lebih banyak dibandingkan dengan pendapatan. Kemudian dari segi

15 Penulis lahir di Malang, 9 September 1990, penulis merupakan Dosen Universitas Nusantara PGRI Kediri pada program studi pendidikan jasmani kesehatan dan rekreasi, penulis menyelesaikan gelar Sarjana Pendidikan Jasmani, Kesehatan dan Rekreasi di Universitas Negeri Yogyakarta (2012), sedangkan gelar Magister Pendidikan diselesaikan di Universitas Negeri Yogyakarta Program studi Ilmu Keolahragaan (2016). 
psikologi banyak manusia mengalami stres pada situasi seperti ini. Berkaitan dalam menjalin komunikasi dan relasi yang baik antar sesama manusia ternyata harus dibatasi dengan adanya Covid-19 ini, dan di dalam kehidupan beragama ketika menjalankan kegiatan keagamaan saat ini beralih dengan live streaming dan kegiatan itu sungguh membutuhkan tenaga, pemikiran, dan biaya. Dalam dunia pendidikan juga dipengaruhi oleh situasi Covid-19 ini, saat ini ada aturan tentang jaga jarak, jadi untuk aktivitas pembelajaran yang dilakukan oleh sekolah yaitu dengan menggunakan pembelajaran jarak jauh.

Berbicara tentang pembelajaran jarak jauh dalam paradigma pendidikan 4.0 ini menjadi hal penting bagi pendidik, siswa, maupun orangtua karena situasi wabah Covid-19 yang semua serba dibatasi kegiatan belajar mengajarnya. Jika kita melihat kembali bahwa dalam 3 abad ini kita sudah mengalami revolusi industri sebanyak 4 kali, yaitu era industri 1.0 yang pertama tahun 1784 ditandai dengan adanya mesin uap dalam menggerakkan roda kehidupan ini, terutama didalam hal produksi, yang kedua era industri 2.0 tahun 1870 dimana mesin uap menjadi mesin tenaga listrik. Berikutnya yang ketiga adalah era industri 3.0 tahun 1959 dimana produksi sudah menggunakan mesin yang bergerak dan dapat dikontrol, misalnya komputer atau barang elektronik lainnya. Terakhir yang ke empat adalah era industri 4.0 dimana segala sesuatunya sudah dibantu dengan sarana internet dan jaringan-jaringan.

Dari ke-empat perubahan revolusi industri yang sudah dialami mengubah segala kehidupan termasuk dalam dunia pendidikan. Dalam industri 4.0 sebenarnya pokok utamanya adalah dalam pengembangan teknologi, mau tidak mau pelaku dalam dunia pendidikan harus mengikuti itu dan bukan teknologi 
yang mengatur kita tetapi teknologi hanya sebagai sarana untuk mempermudah kehidupan manusia. Jadi jika diambil kesimpulan bahwa ada 2 hal yang mempengaruhi dunia pendidikan yaitu dalam era indutri 4.0 yang mau tidak mau, siap dan tidak siap harus menggunakan teknologi yang ada dan kedua adalah di pengaruhi oleh situasi wabah Covid-19. Sehingga banyak hal yang mengubah dan bahkan harus berfikir lebih matang lagi berkaitan dengan pendidikan sehingga proses pendidikan harus terus berjalan terus menerus.

Pada situasi seperti ini para pendidik diharapkan untuk tetap hidup dengan penuh harapan, bahwa yang namanya hidup penuh harapan yaitu mampu mengubah suatu ancaman menjadi peluang.Jika kita melihat bahwa pendidikan menjadi pondasi kehidupan suatu bangsa, maka pendidikan sebagai prioritas utama bagi kita semua.Situasi wabah Covid-19 dan era industri 4.0 yang menjadikan ancaman khususnya dalam dunia pendidikan maka seharusnya hal ini menjadi suatu peluang dalam hal digitalisasi dan ini harus kita persiapkan sungguh-sungguh.Pendidik juga harus mampu mengikuti perkembangan teknologi yang canggih ini, teknologi perkembangan yang begitu canggih bisa dijadikan sarana untuk meningkatkan kualitas pendidikan. Pendidik juga harus dipersiapkan dalam menyambut industri 4.0, maka peserta didik akan terbantu karena peserta didik dituntut untuk aktif kreatif dan inovatif yaitu dengan menggunakan sarana atau teknologi.

Solusi langkah dalam proses pembelajaran jarak jauh berbasis teknologi ini yang dilakukan pertama yaitu contextual teaching learning, bagaimana sebuah pembelajaran harus terikat pada sebuah konteks, dalam contextual teaching kalau kita mau merespon keadaan 
tentunya kita harus mendengar keadaan apa yang sedang terjadi. Jika kita akan berkreasi kita harus bisa berjejaring karena jika tidak maka kita akan mengalami kesulitan karena dunia saat ini tanpa jejaring akan menjadi sangat mustahil untuk mengalami kemajuan. Jika kita akan berklaborasi maka kita harus berbagi, kemudian jika kita ingin menemukan sesuatu pemaknaan maka komunitas kelas harus menjadi komunitas pembelajaran.

Ada beberapa hal yang akan dipelajari dalam pembelajaran kontekstual yaitu: (1) Persiapan yang berorientasi pada kompetensi, secara sederhana bahwa ada standart minimal yang harus dipenuhi oleh pendidik, siswa dan dikomunikasikan secara baik kepada orangtua yaitu dimana belajar adalah mengetahui sesuatu, kemudian mampu membuat sesuatu sebagai sebuah keterampilan sehingga ada penghayatan nilai dalam pembentukan karakter. (2) Membuat pemetaan, pendidik harus memetakan kurikulum baik secara satuan pendidikan ataupun secara mata pelajaran, yang dipetakan adalah standart isi, standart proses, standart penilaian, dan standar pelaporannya. Kemudian dalam pemetaan pendidik yaitu pemetaan potensi pendidik, kemampuan pendidik yang dikembangkan karena pendidik sebagai fasilitator, mentor, coach, bahkan sebagai konsultan bagi para siswa. Pemetaan siswa untuk mencapai kompetensi dalam akademik menggunakan taksonomi bloom sehingga proses pembelajaran bisa didesain dan bisa menentukan pencapaian bagi para pendidik maupun para siswa. Menurut Omar, et.al. (2011: 25) “Bloom's Taxonomy is a classification of learning objectives within education that educators set for students". Berikutnya (3) Pahami komponen dasar pembelajaran, komponen ini terkait dalam paradigma pendidikan yang lebih kolabratif, kreatif, dan lebih independen, artinya bahwa 
siswa tidak lagi belajar dengan menggunakan metode lama tetapi harus diajarkan lewat panduan ataupun tutorial maka pendidik harus paham sebagai fasilitator yang memfasilitasi haruslah mempunyai contoh produk sehingga bisa dikembangkan oleh siswa.

Penilaian juga harus lebih jelas artinya apa yang menjadi standar guru menilai bisa dimengerti atau menjadi pedoman bagi para peserta didik dan dikomunikasikan kepada orangtua, sehingga penilaian lebih objektif dalam arti masing-masing pihak berpegang pada aturan dan ukuran yang sama. Selama ini dalam pembelajaran era sebelumnya penilaian hanya guru yang mengetahui dan di dalam proses pembelajaran secara jarak jauh harus objektif sehingga ukuran ketuntusan lebih jelas. Selama ini ketuntusan penilaian hanya diukur pada standar minmal KKM, sementara aspek afektif dan psikomotor sering kali diabaikan.

Secara teoritis tujuan dari pembelajaran mencangkup tiga hal yaitu kemampuan kognitif, kemampuan afektif, dan kemampuan psikomotor.Menurut Bloom (1956: 24) membagi learning domain sebagai tujuan dirumuskan kedalam tiga klasifikasi atau aspek yaitu : (1) aspek kognitif, (2) aspek afektif, dan (3) aspek psikomotor. Dalam pembelajaran jarak jauh hal ini juga perlu dilakukan dengan cara terintegrasi apa yang dipahami, apa yang dirasakan, dan apa dilakukan haruslah menjadi sebuah kesimpulan. Pemetaan Taksonomi Bloom ada tiga hal yang dilatihkan dalam setiap proses pembelajaran yaitu penalaran dasar, penerapan, dan pemahaman. Penalaran dasar diperkuat dengan cara melakukan atau diaplikasikan, setelah diaplikasikan kemudian dikaji ulang dan dikembangkan sehingga dalam proses pendampingan menjadi jelas bahwa didalam diri 
peserta didik ada 3 model penalaran, penerapan, dan pemahaman, dimana melalui pemetaan tersebut pendidik mengetahui kekurangan yang dialami siswa.

Misalnya ada siswa yang belum kuat dalam pengetahuan dasar maka harus diperkuat lagi, jika ada siswa yang sudah kuat dalam pengetahuan dasar maka diarahkan untuk mengaplikasikan.Dengan pola tersebut diatas maka pergerakan pembelajaran jarak jauh bukan hanya lecturing tetapi juga harus membangun literasi.Literasi dan media komunikasi atau media pembelajaran harus diciptakan atau dikreasikan dari segi visual maupun auditori tujuannya adalah supaya mempermudah siswa dalam menangkap sebuah pengetuhuan. Harapan dari adanya pola pembelajaran yang diperkuat dari literasi dan media komunikasi ini maka peserta didik akan mudah mengembangkan dalam sebuah praktik dan hasil praktik tersebut didiskusikan sehingga akan muncul sebuah penalaran, maka dari proses pembelajaran seperti itu akan tercipta pembelajaran yang disebut learning by doing.

Bentuk materi pembelajaran jarak jauh yaitu (1) lembar kerja siswa, dan (2) video pembelajaran, yang mana didalam kedua meteri tersebut ada kegiatan pendahuluan, kegiatan inti, dan kegiatan penutup. Harapannya dari materi pembelajaran jarak jauh adalah siswa dapat mengikuti proses pembelajaran secara lengkap. Dalam materi pembelajaran jarak jauh komponen yang ada dalam kegiatan pendahuluan ada : (1) pengantar, (2) doa, dan (3) penjelasan aktivitas, kemudian dalam kegiatan inti ada : (1) penjelasan materi, (2) tugas latihan, dan kegiatan penutup ada : (1) kesimpulan, (2) refleksi, dan (3) doa.

Kesimpulannya adalah bahwa proses pembelajaran tetap memperhatikan pada kualitas. Situasi sekarang ini banyak sekolah yang tidak bisa melakukan 
pembelajaran secara normal, secara normal dalam artian keterbatasan sarana dan prasarana pendukung, seperti sinyal maupun media komunikasi sehingga solusi yang diberikan adalah proses pembelajaran jarak jauh dan mempersingkat durasi pembelajaran tetapi materi tersebut mudah dimengerti oleh siswa. Salah satu contoh pembelajarannya adalah melalui tutorial dan media pembelajaran interaktif yang dikemas dalam video sehingga dalam penyampaian materi supaya lebih mudah. Gagasan ini sifatnya hanya membantu dalam menyikapi situasi wabah Covid-19 sehingga kita diajak untuk siap melakukan pembelajaran jarak jauh. ***

\section{DAFTAR PUSTAKA}

Bloom, B.S (ed). (1956). Taxonomy of educational objective: the classification of educational goals. Handbook I cognitive domain. New York: David McKay Company.

Omar, N. Et. al. (2011).Autmated analysis of exam question according to bloom's taxonomy.Procedia-Sosial and Behavioral Sciences, 59 (2012) 297-303. 
116 | Akademisi dalam Lingkaran Daring 


\section{KENYAMANAN BELAJAR SISWA MENGHADAPI PEMBELAJARAN ONLINE DI MASA PANDEMIC COVID-19}

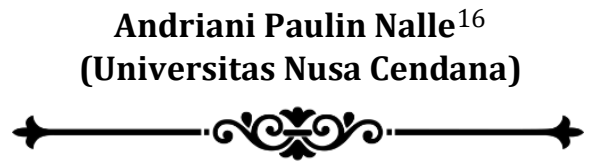

"Kenyamanan dalam belajar berupa suatu perasaan nyaman yang ditunjukkan oleh individu ketika berinteraksi dengan lingkungan melalui proses pembelajaran. Menjaga dan mempertahankan kenyamanan belajar siswa menghadapi pembelajaran online menjadi salah satu poin yang perlu diperhatikan"

Kenyamanan dapat diartikan sebagai suatu bentuk Iperasaan nyaman berdasarkan pandangan dari masing-masing individu. Perasaan nyaman dapat terwujud apabila individu dapat memenuhi kebutuhankebutuhan dasar yang bersifat individual serta diperoleh dari faktor lingkungan. Suatu bentuk kenyamanan yang berasal dari kondisi lingkungan

${ }^{16}$ Penulis lahir di Kupang, 14 April 1983. Penulis merupakan Dosen Universitas Nusa Cendana, Fakultas Keguruan dan Ilmu Pendidikan (FKIP), Program Studi Bimbingan dan Konseling (BK). Penulis menyelesaikan Gelar Sarjana Psikologi pada Universitas Kristen Satya Wacana Salatiga tahun 2005 dan gelar Magister Pendidikan pada bidang Psikologi Kognitif di Flinders University, Adelaide, South Australia, tahun 2016. 
sekitar individu dapat berupa rangsangan seperti warna, bau, simbol, suhu, cahaya dan lain-lain. Setiap individu mempersepsikan perasaan nyaman tersebut sangat bergantung pada situasi dan kondisi yang dialaminya dalam lingkungan. Rangsangan yang diterima oleh panca indera akan diteruskan ke otak untuk diproses. Otak akan melakukan penilaian terhadap rangsangan yang diperoleh apakah memberikan rasa nyaman atau tidak. Perasaan nyaman itu sendiri dapat berupa suatu kelegaan, kepuasaan, keharmonisan, keamanan, serta terlepas dari gangguan yang mengancam diri individu.

Kemudian, kata belajar diartikan sebagai perubahan tingkah laku yang merupakan hasil interaksi antara individu dengan lingkungannya (Pane \& Dasopang, 2017). Interaksi yang terjalin melalui latihan-latihan dan pengalaman memberikan wawasan dan pengetahuan baru bagi individu sehingga membentuk sebuah perubahan perilaku yang bersifat positif dan cenderung permanen, baik perubahan kognitif, afektif maupun psikomotorik. Apabila tidak ada perubahan perilaku maka tidak ada pembelajaranyang terjadi. Proses belajar yang diikuti dengan konsekuensi yang menyenangkan cenderung akan diulangi dan dipertahankan oleh individu, dan sebaliknya. Berdasarkan uraian di atas, maka dapat ditarik kesimpulan bahwa kenyamanan dalam belajar berupa suatu perasaan nyaman yang ditunjukkan oleh individu ketika berinteraksi dengan lingkungan melalui proses pembelajaran. Perasaan nyaman dalam belajar nampak dalam tingkah laku individu yang merasa sejahtera, aman, lega, puas dan terbebas dari rasa khawatir. 


\section{Kenyamanan Belajar Dari Rumah (BDR) Secara Daring di Masa Pandemi}

Di tengah situasi pandemic covid-19 yang tak berkesudahan, orangtua dituntut untuk mendampingi anak selama melaksanakan pembelajaran daring di rumah. Oleh karena itu, orangtua harus menjaga kenyamanan belajar anak ketika mengikuti mata pelajaran maupun ujian yang terlaksana secara online. Selain sarana dan prasarana yang perlu disiapkan, penataan lingkungan fisik tempat belajar anak juga membutuhkan perhatian orangtua, seperti suasana rumah yang kondusif sehingga memberikan rasa nyaman ketika belajar dan beraktivitas. Selain itu, guru selaku pengajar diharapkan dapat mendesain pembelajaran dengan memanfaatkan media yang tepat, yang bersifat kreatif sekaligus inovatif, sehingga siswa memperoleh kesempatan untuk menggali potensi yang dimiliki sertamerasakankenyamanan dalam belajar.

Kenyamanan siswa dalam belajar secara online dapat diperoleh dari lingkungan melalui sarana dan prasarana yang mendukung. Namun, salah satu kendala yang dialami sistem pembelajaran daring adalah jaringan internet yang buruk. Pada beberapa wilayah di Indonesia bahkan tidak memiliki jaringan internet, serta masih ada orangtua maupun siswa yang tidak memiliki perangkat elektronik yang dapat dihubungkan pada internet, seperti Laptop atau Handphone (HP). Survey yang dilakukan oleh Unicef melalui kanal U-Report pada bulan Mei dan Juni tahun 2020 lalu (Kompas online, 24 Juni 2020), 35 persen dari 60 juta siswa di 34 provinsi menyebutkan akses internet yang buruk merupakan salah satu alasan ketidaknyamanan belajar daring dari rumah. Selain itu, faktor utama yang menyebabkan ketidaknyamanan siswa adalah kurang mendapatkan bimbingan dari guru (38 persen). Ditambahkan pula, hasil survey mengungkapkan bahwa 66 persen siswa 
dari berbagai jenjang pendidikan di Indonesia mengaku tidak nyaman selama belajar dari rumah.

Selain masalah jaringan internet, paket atau kuota dan keterbatasan perangkat elektronik, masalah lain yang timbul adalah adanya kejenuhan siswa melakukan belajar dari rumah secara online. Beberapa siswa memiliki tingkat aktivitas yang cukup tinggi, seperti kegiatan ekstrakurikuler, organisasi, olahraga, dan lainlain, di luar jam sekolah. Kegiatan-kegiatan informal tersebut membantu anak belajar membangun psikososial dan interaksi yang lebih luas di lingkungan masyarakat. Ketika pandemi covid-19 menjadi permasalahan dunia, siswa diwajibkan melakukan isolasi diri dan membatasi kegiatan tertentu di luar rumah bahkan Pembatasan Sosial Berskala Besar (PSBB). Dampaknya, anak merasakan kesepian, stres, jenuh, hilang konsentrasi belajar, dan ketidaknyamanan Belajar Dari Rumah (BDR) karena rendahnya aktivitas di dalam rumah serta interaksi bersama teman-teman sebaya.

Meskipun beberapa hal yang diungkapkan di atas merupakan bentuk ketidaknyamanan siswa menghadapi pembelajaran online, namun, perlu digarisbawahi beberapa poin positif selama melaksanakan kegiatan belajar secara online. Studi terbaru yang dilansir dari Healthline (Klikdokter.com) menyatakan bahwa masih banyak para remaja yang menikmati belajar secara online dari rumah. Melalui BDR, siswa dapat menghubungi guru secara personal terkait keluhan-keluhan yang dihadapi dan merasa lebih dekat dengan gurunya. Selain itu, sejak diberlakukannya sekolah online, presentase kecemasan siswa-siswi turun 10-16 persen dan kepuasan belajar semakin meningkat. Seorang pakar psikologi, Gracia Ivonika, M.Psi., Psikolog, menjelaskan bahwa pada masa pandemic, anak tidak 
bertemu secara langsung dengan teman yang mungkin sering mengganggunya dan lingkungan kelas atau sekolah yang kotor sehingga BDR membuat anak merasa lebih nyaman. Anak dengan karakter tenang akan lebih mudah berkonsentrasi serta fokus pada pembelajaran karena minimnya gangguan.

Selain itu, anak akan semakin nyaman belajar apabila didukung dengan situasi rumah yang tenang, dan kondusif, sehingga online learning membentuk suatu kebiasaan baru yang menyenangkan bagi anak. Ditambahkannya bahwa anakpun memiliki lebih banyak waktu untuk beristirahat, berinteraksi bersama orangtua dan anggota keluarga lainnya, ataupun melakukan aktivitas lain yang diminatinya. Anak tetap dapat menjalin komunikasi bersama teman sebaya atau teman sekelas melalui platform-platform seperti group Whats'App (WA), Instagram, Facebook, Microsoft teams ataupun media online lainnya. Belajar tetap dapat dilaksanakan di mana saja dan kapan saja tanpa terbatasi oleh ruang dan waktu.

Pandemic covid-19 yang masih berkelanjutan menjadi permasalahan di seluruh dunia. Perubahan terjadi hampir di semua aspek kehidupan manusia, terutama pada dunia pendidikan. Menjaga dan mempertahankan kenyamanan belajar siswa menghadapi pembelajaran online menjadi salah satu poin yang perlu diperhatikan. Oleh karena itu, berikut adalah beberapa strategi untuk mempertahankan rasa nyaman selama belajar dari rumah :

\section{Komunikasi aktif orangtua dan wali kelas}

Guru, kepala sekolah, dan orangtua bertanggungjawab atas pendidikan anak selama BDR. Dengan demikian, orangtua diwajibkan terus membangun komunikasi yang aktif bersama pihak sekolah, terutama wali kelas terkait kemajuan 
belajar anak. Selain itu, orangtua juga dapat menyampaikan kendala-kendala yang dihadapi ketika pembelajaran online dilaksanakan. Hal ini dilakukan agar anak mendapatkan pengarahan yang tepat dan merasa nyaman selama BDR.

\section{Tersedianya sarana dan prasarana yang} mendukung

Dukungan sarana prasarana dapat mempertahankan kenyamanan belajar anak. Sarana prasarana meliputi jaringan internet yang stabil, kuota yang terpenuhi, perangkat elektronik yang menunjang, pencahayaan ruangan, situasi yang kondusif di rumah serta minimnya gangguan.

\section{Mengutamakan prioritas}

Orangtua perlu membimbing anak untuk dapat memprioritaskan pendidikan. Salah satu yang dapat dilakukan adalah meminta anak menjauhkan benda-benda yang dapat mendistorsi konsentrasi dan fokus belajarnya, seperti menonaktifkan HP selama belajar.

\section{Mengatur waktu dengan baik}

Tidak dapat dipungkiri bahwa BDR mengakibatkan anak lebih banyak menghabiskan waktu di rumah. Oleh karena itu, guru perlu mengingatkan siswa untuk dapat mengatur waktu dengan baik. Orangtua membantu membimbing anak agar dapat menyelesaikan tugas tanpa menunda-nunda, mengatur jam belajar di rumah, dan juga merangkum materi yang dipelajari.

\section{Diskusi dengan guru bila menghadapi kesulitan}

Selain komunikasi aktif dari orangtua bersama guru, anak atau siswa pun diarahkan untuk tetap menjalin diskusi dengan guru terkait materi atau pelajaran yang dianggap sulit. Komunikasi yang 
baik dapat mengembangkan kemampuan psikososial anak serta dapat memberikan rasa nyaman, menurunkan kecemasan anak bahkan membangun hubungan erat guru-siswa meskipun dilakukan secara virtual.

\section{Melakukan refreshing atau melakukan hal-hal positif}

Selain memperhatikan poin-poin di atas, salah satu strategi yang tak kalah penting adalah refreshing. Meskipun lebih banyak menghabiskan waktu di rumah, namun banyak hal-hal positif yang dapat dilakukan anak agar tetap nyaman BDR. Orangtua dapat menemani anak menonton acara kesukaannya, melakukan hobinya, menemani anak bermain, membaca buku, atau sesekali mengajak anak mengunjungi tempat-tempat wisata yang tidak ramai, dan lain-lain. Dengan demikian, anak mendapatkan energi dan semangat baru untuk menghadapi pembelajaran online serta kenyamanan belajar di masa pandemic. ${ }^{* * *}$

\section{DAFTAR PUSTAKA}

Ayu Maharani (2020). Anak lebih nyaman sekolah online, bisa jadi ini alasannya! Klikdokter.com https://www.klikdokter.com/infosehat/read/3645826/anak-lebih-nyamansekolah-online-bisa-jadi-ini-alasannya

Ayunda Pininta Kasih. (2020). Survei Unicef: 66 persen siswa mengaku tak nyaman belajar di rumah. Kompas.com, onlinehttps://edukasi.kompas.com/read/2020/0 6/24/090832371/survei-unicef-66-persensiswa-mengaku-tak-nyaman-belajar-di-rumah 
Pane, A., \& Dasopang, M. D. (2017). Belajar dan pembelajaran. Fitrah: Jurnal Kajian Ilmu-Ilmu Keislaman, 3(2), 333-352. 


\title{
KAJIAN MAHASISWA DARING: SOLUSI PENDIDIKAN KARAKTER DI MASA PANDEMI
}

\author{
Danni Nursalim, Lc. Dipl. I.S. ${ }^{17}$ \\ (Yayasan Bakti Anam Harning (BINAR) Bandung)

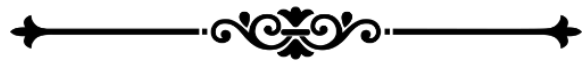

"Terdapat lima nilai karakter utama yang bersumber dari Pancasila, yang menjadi prioritas pengembangan gerakan PPK; yaitu religius, nasionalisme, integritas, kemandirian dan kegotongroyongan"

$\mathrm{N}$ ilai karakter religius mencerminkan keberimanan terhadap Tuhan yang Maha Esa yang diwujudkan dalam perilaku melaksanakan ajaran agama dan kepercayaan yang dianut, menghargai perbedaan agama, menjunjung tinggi sikap toleran terhadap pelaksanaan ibadah agama dan kepercayaan lain, hidup rukun dan damai dengan pemeluk agama lain.

\footnotetext{
${ }^{17}$ Penulis lahir di Bandung, 01 Juli 1974. Penulis merupakan seorang da'i yang banyak berkecimpung di kalangan mahasiswa di Bandung, merupakan salah satu pengurus Yayasan Bakti Anam Harning (BINAR) di Bandung, yang bergerak dalam bidang pendidikan, sosial dan ekonomi. Penulis menyelesaikan gelar sarjana S1 di Islamic \&Arabic Studies, AlAzharUniversity, Cairo, Egypt (1999). Post Degree Diplome di Islamic Studies Institute, Giza, Egypt (2002), dan sedang menyelesaikan Magister Tafsir waUlumul Qur'an di MEDIU, Malaysia. Pernah menjadi Dosen di Politeknik Negeri Bengkalis Riau (2011 - 2016), dan Kepala Sekolah SMPS Plus Muhammadiyah Bengkalis, Riau (2014-2016).
} 
(Kemendikbud RI, 2017) Nilai karakter religius, yang merupakan nilai yang pertama dan utama dalam pendidikan karakter, ternyata tidak mendapatkan porsi yang cukup dalam sistem pendidikan Indonesia. Dan itu merata di semua jenjang pendidikan, mulai dari pendidikan dasar sampai dengan di perguruan tinggi. Hal itu berdasarkan pengalaman penulis sendiri yang sempat bertugas menjadi dosen Pendidikan Agama Islam di sebuah perguruan tinggi di salah satu pulau terluar di Indonesia.

Porsi penanaman karakter religius di perguruan tinggi hanya mendapatkan 3 SKS dan hanya satu semester saja. Tentu ini sangat tidak memadai untuk menanamkan karakter yang religius. Apalagi jika para mahasiswa dalam pendidikan agamanya hanya mengandalkan pendidikan di sekolah, dan tidak pernah mendapatkan pendidikan di madrasah-madrasah sore, seperti Madrasah Diniyah Takmiliyah Awaliyah (MDTA) dan semisalnya, maka pemahaman mereka kepada agamanya sangat kurang. Sehingga nilai karakter religius yang diharapkan akan sangat sulit untuk tercapai.

Hasilnya bisa terlihat di lapangan. Bahwa dari sekian mahasiswa yang ada, yang benar-benar paham dengan ajaran agamanya (terutama agama Islam, sesuai bidang penulis), itu tidak mencapai $30 \%$ dari jumlah keseluruhan mahasiswa yang ada. Bahkan penulis sendiri selalu menemukan kasus, bahwa banyak di antara mahasiswa/i yang tidak tahu tata cara salat yang benar, padahal itu merupakan ibadah harian. Bahkan banyak juga di antara mereka yang malah tidak rutin menjalankan kewajiban salat. Ini menunjukkan bahwa nilai karakter religius mereka masih sangat rendah.

Ini fenomena yang sangat mengkhawatirkan dan itu terjadi ketika pembelajaran offline / tatap muka. Lalu 
bagaimana dengan pembelajaran online / daring, di mana para pengajar tidak bertemu langsung dengan anak-anak didiknya? Maka dapat diprediksikan bahwa penanaman nilai karakter religius akan semakin sulit. Mungkin ada yang menjawab, bahwa di kampus ada Unit Kegiatan Mahasiswa yang bergerak di bidang keagamaan. Namun sejauh pengamatan penulis, ini pun tidak efektif, karena kebanyakan yang mengisi adalah sesama mahasiswa/i saja. Atau senior membina junior. Sedangkan pembina itu sendiri tidak mempunyai riwayat belajar agama secara spesifik. Sehingga akhirnya hanya sekedar sharingpengalaman dan kontemplasi saja, tanpa menyentuh penanaman nilai yang mendasar dalam agama itu sendiri.

Sejak kembali ke Bandung (pertengahan 2016), telah berkecimpung dalam dunia dakwah kampus. Dalam artian, mengadakan kajian-kajian keislaman bagi para mahasiswa/i yang ada di kota Bandung, terutama di kampus ITB, UPI, UNPAD dan UNPAS. Mereka semua tergabung dalam wadah kajian mahasiswa, yang tidak berafiliasi ke kampus masing-masing atau bukan termasuk Unit Kegiatan Mahasiswa. Sebagai contoh adalah Udrussunnah Bandung, yang digagas para mahasiswa/i ITB, dan Chaser yang digagas para mahasiswa/i UPI. Walaupun komunitas kajian mahasiswa ini sangat kecil, jika dibandingkan dengan jumlah mahasiswa yang ada, namun setidaknya bisa menjadi setitik embun pelepas dahaga di tengah kemarau berkepanjangan. Pasang surut peserta kajian ini merupakan sunnatullah, namun tidak sedikit juga yang tadinya buta sama sekali dengan bahasa Arab dan ilmu-ilmu keislaman yang murni, sampai kemudian mahir dan bisa bersaing dengan para santri di dalam membaca kitab-kitab Arab karya-karya ulama klasik. 
Kajian berlangsung di masjid-masjid yang bertebaran di sekitar kampus, atau di masjid kampus itu sendiri. Waktu pelaksanaan adalah sekitar jam 16.00, walaupun nanti juga tetap akan ada anggota komunitas yang berhalangan, karena ada kuliah sore atau praktikum yang tidak bisa ditinggalkan. Adapun yang dipelajari adalah kitab-kitab klasik berbahasa Arab, yang ditulis para ulama-ulama Islam masa dahulu. Semua wajib memiliki kitab yang dipelajari, dan Alhamdulillah ada donatur yang selalu siap untuk menyediakannya. Walaupun sebagian besar mereka masih buta dengan bahasa Arab, namun kemudian mereka menjadi tertarik untuk mempelajari bahasa Arab dengan lebih lanjut.

Selain untuk mengisi kekurangan dalam pendidikan karakter di kalangan mahasiswa, kajian-kajian seperti ini juga untuk menghindarkan mahasiswa/i dari pemahaman-pemahaman yang tidak benar dalam Islam. Sebab dengan mempelajari langsung dari sumbernya, berupa kitab klasik, dan bukan hanya sekedar tematik, mereka akan tahu ajaran Islam yang sebenarnya. Sehingga tertanam aqidah / keyakinan yang lurus dan semangat beribadah yang kuat. Dalam Islam, akhlak / etika itu berkaitan dengan erat dengan aqidah. Jika aqidahnya lurus, maka akhlaknya pasti mulia. Selain mereka juga akan terhindar dari pemahaman kelompok-kelompok sempalan yang merusak bangsa dan negara dengan mengatasnamakan agama Islam, padahal agama Islam berlepas diri dari itu semua.

Sejak masa pandemi Covid-19, kajian terhenti mulai dari pertengahan Maret 2020. Tentu hal ini menjadikan kekosongan baru dalam penanaman nilai karakter religius di kalangan mahasiswa/i muslim. Namun seiring berkembangnya pembelajaran daring dengan menggunakan media Zoom atau Google Meeting, maka 
komunitas kajian mahasiswa pun mencoba untuk menghidupkan kembali kajian keislaman dengan sistem daring. Awalnya ada sedikit keraguan, karena beberapa hal;

1. Waktu pelaksanaannya. Karena tentu tidak bisa disamakan dengan tatap muka.

2. Pesertanya. Karena untuk kajian 60 - 90 menit itu menghabiskan data yang tidak sedikit. Dikhawatirkan akan menjadi kendala bagi mahasiswa, karena harus menyediakan data yang tidak sedikit, jika kajian itu rutin diadakan seminggu beberapa kali. Karena dalam perkuliahan rutin pun mereka menggunakan data.

3. Materinya. Dikhawatirkan materi yang disampaikan terasa membosankan, mengingat langsung memakai kitab yang berbahasa Arab.

Namun setelah dicoba, ternyata hasilnya cukup menggembirakan. Ketika pembukaan kajian daring, jumlah mahasiswa/i yang mendaftar untuk ikut lebih dari 100 orang, yang tersebar di berbagai daerah di Indonesia. Ini malah melebihi kajian tatap muka, yang ketika pembukaan pun jarang mencapai 100 orang. Dan ketika berjalan, itu hanya ada di angka $20-40$ orang. Akhirnya, kajian keislaman mahasiswa bisa terlaksana lagi secara rutin dengan sistem daring, dengan melanjutkan materi yang terhenti ketika kajian tatap muka beberapa bulan sebelumnya. Setelah berjalan beberapa lama, penulis melihat ada beberapa keuntungan dalam kajian daring ini.

1. Waktunya lebih leluasa, karena diadakan malam hari (19.30 s.d. 21.00). pada saat itu, sebagian besar mahasiswa/i sudah tidak ada perkuliahan. Pada tatap muka, waktu seperti ini hampir mustahil dilakukan. 
2. Pesertanya fleksibel. Karena mereka mengikuti kajian di rumah masing-masing, tidak perlu keluar rumah. Sehingga lebih tenang dan lebih aman.

3. Langsung terkoneksi dengan media sosial lain seperti youtube. Sehingga kajian itu menjadi terdokumentasikan dan siapapun bisa menyaksikannya kembali ketika dibutuhkan.

4. Peserta jadi tidak terbatas hanya kalangan mahasiswa saja, tapi juga kalangan lain, tanpa harus merasa minder kalau mereka bukan mahasiswa. Sehingga manfaat dari kajian ini lebih tersebar luas.

Itulah sekilas tentang dinamika Kajian Keislaman Mahasiswa secara daring yang telah dijalankan oleh penulis dan beberapa rekan-rekan lainnya dalam beberapa bulan terakhir. Mudah-mudahan hal ini ikut memberikan sumbangsih dalam penanaman nilai religius di kalangan mahasiswa muslim, dan bisa dikembangkan oleh rekan-rekan da'i atau para pendidik lainnya. ${ }^{* * *}$

\section{DAFTAR PUSTAKA}

Kemendikbud RI. (2017). Penguatan Pendidikan Karakter Jadi Pintu Masuk Pembenahan Pendidikan Nasional. Diakses dari https://www.kemdikbud.go.id/main/blog/2017/ 07/penguatan-pendidikan-karakter-jadi-pintumasuk-pembenahan-pendidikan-nasional. 


\title{
PEMBELAJARAN DARING YANG EKONOMIS DAN BERAHLAK MULIA PADA ERA PANDEMI COVID-19
}

\author{
Topo Yono, M.Pd. 18 \\ (Pendidikan Olahraga Universitas Muhammadiyah \\ Jember)

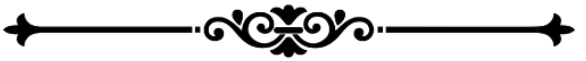

"Teknologi daring yang diterapkan dalam suatu pembelajaran yang dijalankan saat ini memerlukan finansial tidak sedikit. Diperlukan kecerdasan dalam pemilihan media dalam penyampaian pendidikan terhadap siswa maupun mahasiswa."

Desatnya perkembangan teknologi informasi dan komunikasi membawa perubahan yang teramat besar di bidang kehidupan seperti perdagangan, transportasi, pemerintahan hingga dunia pendidikan. (Baihaqi, 2017). Roh di dalam dunia pendidikan mulai bergeser dari pembelajaran konvensional menuju pembelajaran yang serba teknologi ini merupakan hikmah yang kita peroleh dari wabah covid 19. Semua merupakan tuntutan dalam pendidikan, model atau trik apa yang sekiranya cocok untuk diterapkan berjalannya

18 Penulis adalah dosen di Pendidikan Olahraga Universitas Muhammadiyah Jember. Email: bisa dihubungi di alamat topoyono@unmuhjember.ac.id 
waktu silih bergantinya metode di dalam carut marut pendidikan. Sebagai pendidik perlu cara yang jituuntuk penerapannya dalam lingkungan pembelajaran dan bisa mewakili dari semua kalangan sekiranya tidak memberatkan peserta didik, orang tua serta tenaga pengajar itu sendiri.

Teknologi daring yang diterapkan dalam suatu pembelajaran yang dijalankan saat ini pasti memerlukan finansial tidak sedikit baik orang tua maupun pendidik itu sendiri, solusi solusi yang harus tepat misalkan dalam memilih media apa yang cocok dan tidak berbayar dan tidak ada batasan waktu dalam penggunannya hemat terjangkau, jaringan luas sehingga semuanya terwadahi tidak ada yang keberatan tanpa paksaan maka semua akan berjalan sesuai tujuan pendidikan. Media pembelajaran dapat merupakan wahana penyalur pesan dan informasi belajar (Muhson, 2010). Semua diperlukan kecerdasan dalam pemilihan media dalam penyampaian pendidikan terhadap siswa maupun mahasiswa. Proses pembelajaran yang efektif seyogyanya dapat menciptakan suasana kelas atau iklim kelas yang kondusif sehingga terciptanya kualitas proses pembelajaran (Mustika, 2015).

Bermacam macam media yang ada seperti whatshapp, Bip, zoom, google meet, google clasroom, Microsoft Teams serta banyak lagi yang lain. Perkembangan teknologi yang semakin canggih menjadi sarana penting untuk mencapai tujuan pendidikan yang lebih efektif dan efesien (Tafonao, 2018). Pemilihan media yang murah sangat menguntungkan bagi peserta didik maupun pendidik dari beberapa media yang ada whatshapp sebagai sarana yang murah untuk digunakan karena rata rata ponsel memiliki aplikasi whatshapp dalam sarana komunikasi dalam kehidupan sehari hari. 
Media sumber belajar adalah sesuatu yang dapat mengandung pesan untuk disajikan melalui penggunaan alat ataupun oleh dirinya sendiri dapat pula merupakan sesuatu yang digunakan untuk menyampaikan pesan yang tersimpan di dalam bahan pembelajaran yang akan dberikan (Hafid, 2011). Tentunya juga memiliki kekurangan dan kelebihan dalam setiap media seperti dalam whatshapp bisa mengirim pesan, gambar, video dan video call secara berkelompok namun tidak bisa secara langsung memantau apa yang dikerjakan oleh peserta didik karena tidak secara kontinue menanpakkan wajah seluruh peserta belajar yang rawan dimanfaatkan orang tua untuk membantu anaknya dalam mengerjakan tugas yang diberikan oleh gurunya sifatnya hanya penugasan lemah dalam pengawasan.

Pendayagunaan teknologi dalam proses pembelajaran menjadi keharusan sehingga proses pembelajaran tidak stagnan dan kaku. (Nurdin, 2016). Pembelajaran aman nyaman dan murah perlu kita terapakan, google meet adalah trik jitu yang harus kita lakukan dalam pembelajaran murah tidak berbatas waktu bisa memantau seluruh aktivitas dari anak didik dengan mewajibkan mengaktifkan seluruh kamera, semua akan tampak apa saja yang dilakukan oleh siswa atau peserta didik mereka tidak bisa bermain main terpusat pada pembelajaran yang di sampaikan oleh guru. Kelas akan menjadi aktif tentu semuanya harus dikemas dengan menarik dan mudah dipahami dan mereka tidak merasa bosan apa kita sampaikan misalkan menampilkan video pembelajaran serta aktivitas aktivitas yang berkaitan pada suatu topik pembelajaran. Peranan teknologi informasi yang merupakan perpaduan antara teknologi komputer dengan teknologi komunikasi yang diperlukan dalam era informasi. (Mildawati, 2000). Jaringan akan menjadi 
persoalan ketika jaringan tidak mendukung secanggih apapun peralatan komunikasi yang kita miliki tapi jaringan terkendala semuanya tidak akan berarti maka peran pemerintah pusat maupun daerah sangat diperlukan untuk memastikan jaringan semua tersedia merata di pelosok tanah air bahu membahu untuk mensukseskan pembelajaran demi terciptanya pendidikan yang bermutu demi masa depan generasi penerus bangsa.

Ajaran Islam menawarkan kesempatan untuk memahami Sunnatullah serta menegaskan tanggung jawab manusia.(Masruri, 2014). Ajaran yang kita terima baik di sekolah lingkungan maupun orang tua semua mengajarkan ahlak mulia bagaiman hormat menghormati, sopan santun, patuh terhadap perintah orang tua, guru, orang yang lebih tua serta teman sejawat. Krisis moral dalam masyarakat antara lain ditandai olehhilangnya kejujuran, hilangnya rasa tanggung jawab, tidak mampu berpikir jauh ke depan, rendahnya disiplin, krisis kerjasama, krisis keadilan, dan krisis kepedulian.

Pendidikan merupakan salah satu kebutuhan pokok manusia modern. (Djakfar et al., 2010). Dalam dunia serba canggih ahlak yang mulia harus tetap tegak dibumi pertiwi jangan mau dikalahkan oleh teknologi dan media canggih yang kita nikmati pada saat ini tetap junjung tinggi kejujuran, tanggung jawab dan kepedulian terhadap sesama. Semua hanya sebagai sarana menunjang dalam pendidikan tetap menjaga kesopanan terhadap guru lebih lebih terhadap orang tua yang membesarkan dan membiyai pendidikan kita, teknologi dan media tetap diikuti berjalan sebagai mana mestinya, namu ahlak mulia adalah nilai yang paling tinggi di atas segala galanya selalu mengikuti perkembangan teknologi dan juga perkembangan 
akhirat keduanya saling terkait.Suksespembelajaran dengan menggunakan media dan teknologi, sukses tujuan akhir kita adalah akhirat semua perlu bekal akhirat yang hakiki. Hidupmu akan mulia dan tinggi jika ahlakmu mulia tetap terjaga dan terawat dan dicintai Allah, teknologi dikuasai sebagai bekal ibadah semuanya harus tetap abadi dalam sanubari yang paling dalam. $* * *$

\section{DAFTAR PUSTAKA}

Baihaqi, M. B. (2017). Pendidikan dan Digitalisasi di Era Milenial. Sabtu, 23/12/17.

Djakfar, L., Indriastuti, A. K., \& Nasution, A. S. (2010). Studi Karakteristik Dan Model Pemilihan Moda Angkutan Mahasiswa Menuju Kampus ( Sepeda Motor Atau Angkutan Umum ) Di Kota Malang. Jurnal Rekayasa Sipili.

Hafid, H. A. (2011). Sumber dan Media Pembelajaran. Jurnal Sulesana.

Masruri, U. N. (2014). Pelestarian Lingkungan dalam Perspektif Sunnah. At-Taqaddum.

MEMBENTUK KARAKTER SISWA SEKOLAH DASAR MENGGUNAKAN PENDIDIKAN JASMANI DAN OLAHRAGA. (2015). Journal of Physical Education Health and Sport. https://doi.org/10.15294/jpehs.v2i2.4588

Mildawati, T. (2000). Perkembangan Teknologi Informasi Di Indonesia. Ekuitas.

Muhson, A. (2010). PENGEMBANGAN MEDIA PEMBELAJARAN BERBASIS TEKNOLOGI INFORMASI. Jurnal Pendidikan Akuntansi 
Indonesia.

https://doi.org/10.21831/jpai.v8i2.949

Mustika, Z. (2015). Urgenitas Media Dalam Mendukung Proses Pembelajaran Yang Kondusif. CIRCUIT: Jurnal Ilmiah Pendidikan Teknik Elektro. https://doi.org/10.22373/crc.v1i1.311

Nurdin, A. (2016). INOVASI PEMBELAJARAN PENDIDIKAN AGAMA ISLAM DI ERA INFORMATION AND COMMUNICATION TECHNOLOGY. TADRIS: Jurnal Pendidikan Islam. https://doi.org/10.19105/tjpi.v11i1.971

Tafonao, T. (2018). PERANAN MEDIA PEMBELAJARAN DALAM MENINGKATKAN MINAT BELAJAR MAHASISWA. Jurnal Komunikasi Pendidikan. https://doi.org/10.32585/jkp.v2i2.113 


\section{GAMBARAN KEJENUHAN MAHASISWA MENGIKUTI PEMBELAJARAN DARING DI MASA PANDEMI}

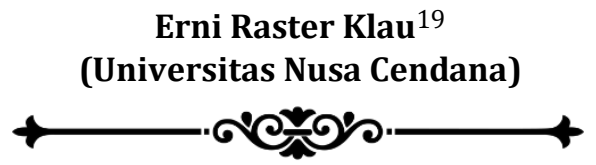

"Selama pembelajarn daring masalah utama yang muncul adalah lebih ditekankan pada kejenuhan dalam hal kelelahan emosional yang dialami para mahasiswa. Pembelajaran daring baiknya juga menjadi proses yang menyenangkan, sehingga kejenuhan bisa diminimalisir."

Derubahan-perubahan dalam kehidupan masa kini sejak masuknya Covid-19 hingga ditetapkannya sebagai pandemi, secara sadar telah mengubah kondisi dan keadaan di banyak sektor. Sektor Pendidikan misalnya, oleh Hidayat, (2020) dalam tulisannya di laman tirto.id menegaskan tentang salah satu kebijakan kurikulum yang dikeluarkan oleh Menteri Pendidikan dan Kebudayaan, yang singkatnya bahwa selama proses

19 Penulis lahir di Kupang, 27 Juni 1985. Penulis sebagai Dosen di Universitas Nusa Cendana, Fakultas Keguruan dan Ilmu Pendidikan (FKIP), Program Studi Pendidikan Luar Sekolah (PLS). Penulis menyelesaikan Gelar Sarjana di Fakultas Psikologi, Universitas Kristen Satya Wacana Salatiga pada tahun 2007 dan menyelesaikan studi magister pada bidang Psikologi Sosial di Universitas Gadjah Mada, Yogyakarta tahun 2015. 
belajar daring, sekolah atau Lembaga Pendidikan sedapat mungkin menerapkan kurikulum adaptif. Namun, dalam praktiknya, tidak dipungkiri bahwa tidak semua Lembaga menjalankan kebijakan tersebut dan tetap mengacu pada pemenuhan kurikulum nasional sehingga cukup banyak kendala dihadapi dalam praktik belajar mengajar secara daring. Hal ini juga tentu dikaitkan dengan kompleksitas masalah Pendidikan di kota dan daerah.

Lebih lanjut, Hidayat pun menambahkan pernyataan seorang Kepala Sekolah, bahwa secara sederhana persoalan sekolah daring adalah semata memindahkan seluruh jadwal dan proses pembelajaran ke dunia maya. Namun di sisi lain, kelanjutannya memunculkan kondisi kompleks yang kian berjalan hingga kini. Salah satu yang menarik, dialami Mahasiswa Pendidikan Luar Sekolah (PLS) Universitas Nusa Cendana adalah berada dalam kondisi jenuh. Kejenuhan belajar atau juga diistilahkan dengan burnout dapat diartikan kondisi emosional seseorang yang merasa lelah dan jenuh secara mental maupun fisik sebagai akibat dari tuntutan suatu pekerjaan yang kian meningkat (Slivar, 2001). Tuntutan dimaksud adalah jelas dalam hal proses belajar.

Pembelajaran daring di sisi berbeda, menjadi proses yang menarik bagi mahasiswa. Faktor-faktor penting yang berpengaruh seperti dosen/pengajar mendesain pembelajaran yang tidak monoton, perangkat teknologi yang mendukung bahkan lingkungan fisik yang kondusif. Namun di sisi lain, kejenuhan belajar pun merupakan kondisi kelelahan emosional yang tidak terhindarkan dialami mahasiswa karena berbagai tuntutan dan tekanan yang dilihat dari berbagai aspek individu itu sendiri. 


\section{Kejenuhan Belajar}

Kejenuhan belajar atau burnout belajar tidak dapat dianggap sebagai hal sepele bagi mahasiswa. Hal tersebut sebenarnya bukan perkara baru yang dialami oleh para pembelajar, karena dalam pertemuanpertemuan luring pun, kejenuhan belajar dapat saja terjadi, namun yang ditemui selama pembelajarn daring adalah lebih ditekankan pada kejenuhan dalam hal kelelahan emosional yang dialami para mahasiswa. Seperti dinyatakan Slivar (2001), pada efek yang berkepanjangan dan tidak tertangani, stress akan memunculkan gejala kejenuhan (burnout syndrom). Agustina, Bahri \& Abu Bakar, (2019) dalam tulisannya menguraikan kondisi jenuh atau bosan seperti halnya tidak mampu bekerja untuk memproses informasi atau pengalaman baru sesuai harapan. Kondisi emosional tersebut ditunjukkan dengan kelelahan baik secara fisik dan mental sebagai akumulasi dari tuntutan belajar yang terus-menerus. Praktik pembelajaran daring dilakukan secara padat atau penuh, berakibat pada kondisi tidak memuat apapun, inilah kondisi jenuh yang sebenarnya.

Rasa bosan dan lelah tersebut mengakibatkan timbulkan kondisi lesu, tidak bersemangat, bahkan tidak adanya gairah terhadap aktivitas belajar. Sederhananya, pengalaman belajar yang baru dan bermakna bagi individu dirasa kurang. Lebih lanjut, kejenuhan belajar dapat diindikasi melalui hasil belajar yang rendah, lamban merespon kegiatan-kegiatan yang berhubungan dengan pembelajaran, menampilkan sikap yang tidak sewajarnya seperti acuh tak acuh, menentang, berpura-pura, kedisiplinan waktu yang kurang, mengganggu, pengaturan aktivitas belajar yang kacau (Agustina, Bahri \& Abu Bakar, 2019). 
Fenomena kejenuhan belajar diuraikan Hidayat, (2020) seperti durasi waktu yang panjang dalam melihat layar ponsel, pembelajaran daring yang kurang interaksi, pengajar dengan pola monolog monoton hingga tugas yang terlampau banyak disetiap hari sekolah tanpa menjelaskan materi tugasnya. Hal serupa, diutarakan beberapa mahasiswa PLS yang Sebagian besar menekankan kejenuhan berdasar pada kurangnya interaksi selama pembelajaran daring, serta kurangnya dukungan orangtua terhadap sarana pendukung seperti perangkat media dan kuota internet. Beberapa mengakui, bahwa selama pembelajaran daring, sekadar hadir untuk memenuhi standar kehadiran dan penilaian dosen, namun tidak berdampak pada pengalaman belajar yang baru, tugas dikerjakan seadanya tanpa memperhitungkan standar kualitas dan efek belajar yang bermakna.

Jika merujuk dari laporan hasil evaluasi Wakil Dekan Bidang Akademik FKIP Universitas Nusa Cendana tentang perkuliahan daring semester genap 2020/2021 (April, 2021) dikaji beberapa faktor dalam praktik pembelajaran daring diantaranya: Jenis media online yang dipergunakan dalam perkuliahan daring dengan memperoleh jumlah persentasi terbesar adalah dengan menggunakan platform Zoom dan Google meet; Aktivitas mahasiswa dalam perkuliahan daring yang berbasis SCL (Student Centered Learning) dalam bentuk diskusi dan tugas mandiri; Durasi waktu dosen dalam memberikan penjelasan selama perkuliahan daring berdurasi waktu lebih dari 40 menit; Frekuensi dosen mengajukan permasalahan selama perkuliahan dilakukan dalam bentuk pembelajaran Problem Based Learning (PBL) dengan hasil 51,5\% dosen selalu mengajukan permasalahan untuk didiskusikan; 65,3\% responden menyatakan dosen selalu memberikan respon atau umpan balik terhadap pertanyaan yang 
diberikan mahasiswa baik saat peerkuliahan maupun saat kegiatan diskusi berlangsung; Frekuensi dosen memberikan masukan sebagai respon terhadap pertanyaan mahasiswa dalam diskusi sebesar 65,3\%; Volume tugas yang diberikan dosen didominasi dalam kategori banyak (34,9\%); Kegiatan review (feedback dan reinforcement) sebagian besar responden (60,1 \%) menyatakan bahwa dosen FKIP Undana selalu memberikan review terhadap tugas mahasiswa.

Sedangkan faktor-faktor lain adalah meninjau dari komponen hubungan persahabatan dosen dengan mahasiswa dalam perkuliahan, penguasaan materi ajar oleh dosen, aspek kesistematisan dosen dalam memberikan penjelasan selama perkuliahan, penampilan dosen saat mengajar secara daring, gambaran dosen yang memberikan kuliah secara tatap muka dalam masa pandemi Covid-19, frekuensi dosen dalam memberikan penjelasan dan penguatan setelah mahasiswa mempresentasikan tugas, kategori dosen dalam memberikan tugas yang disertai penjelasan yang lengkap, kategori penggunaan kata-kata oleh dosen ketika mengajar, gambaran dosen dalam mengunggah RPS dan materi perkuliahan di e-learning atau pada aplikasi Lain, jenis perangkat atau bahan pembelajaran yang diunggah dosen, dan yang terakhir adalah tingkat kepuasan mahasiswa terhadap dosen saat mengajar secara daring.

Faktor-faktor di atas, baik adanya dan dapat dikatakan cukup representatif namun di sisi lain, terlihat seolah pembelajaran menjadi sebuah proses linier semata, pula sebagai sebuah pemenuhan terhadap kontrak kerja antara guru dan peserta didik. Sekian faktor yang dikaji tersebut, belum meninjau faktor psikis berdasar evaluasi kebutuhan psikologis peserta didik. Dengan demikian, wajar jika kejenuhan belajar 
dalam hal ini kelelahan mental yang dialami mahasiswa, tidak terjaring seutuhnya.

Melirik indografik yang dirangkum Hidayat (2020), pembelajaran daring selama kondisi pandemi melahirkan komppleksitas yang belum kunjung usai. Uraian data tersebut dimulai dari kondisi peserta didik yang stres, drop, burnout, jenuh bahkan masuk IGD saat belajar jarak jauh selama musim pandemi. Data juga dilengkapi dengan hasil survei KPAI (20 Propinsi, 54 kabupaten/kota, 1.700 responden) terdapat $73.2 \%$ siswa terbebani tugas, dan $77.8 \%$ lelah dengan tumpukan tugas dan waktu penyelesaian yang terlampau singkat. Juga tambahan data dari Jajak Pendapat PEKA I Unicef Indonesia x CIMSA Indonesia di 32 propinsi, dengan 638 responden pada Agustus 2020, diperoleh $38 \%$ anak tertekan oleh orangtua, $14 \%$ anak tertekan oleh guru, $13 \%$ oleh tekanan teman dan 5\% oleh saudara. Sedangkan pada jajak pendapat PEKA II diakhir Agustus - awal September 2020, terdapat 38\% siswa takut tak mampu memahami pelajaran, 36\% siswa takut pada hasil studinya dan merasa serba tak pasti di masa depan, 10\% menyatakan sulit mengatur waktu belajar.

Jika demikian, maka harapan untuk memenuhi keterampilan kemandirian belajar individu (selfdirected learning) bukanlah perkara mudah. Oktaviyanthi, (2021) dalam tulisannya menekankan tentang self-directed learning yang meliputi kemampuan individu terhadap pengaturan belajar diawali dengan perencanaan, pelaksanaan dan evaluasi pembelajaran yang terarah. Karena semakin tinggi skala kemandirian belajar peserta didik, maka kemampuan untuk mengelola pembelajaran pun semakin baik. Kondisi jenuh belajar, baiknya menjadi rangkaian dalam selfdirected learning yang perlu diantisipasi, karena dengan 
menumbuhkembangkan self-directed learning sama halnya dengan menolong peserta didik mempersiapkan diri menjadi pembelajar seumur hidup (life-long learners) sebagai wujud preventif perubahan situasi dan kondisi lingkungan dan kepentingan dalam segala bidang kehidupan.

Kesehatan mental tak kalah penting dengan Kesehatan fisik, sehingga pembelajaran daring baiknya juga menjadi proses yang menyenangkan dengan upaya meminimalisir dampak psikologis yang juga nanti akan menyerang imunitas. Terakhir, beberapa strategi yang dapat dilakukan untuk meminimalisir kejenuhan belajar pada mahasiswa antara lain:

1. Hubungan interpersonal Dosen dan Mahasiswa seyogyanya terjaga hangat dan professional sehingga mahasiswa tidak sungkan mengutarakan kondisi kejenuhan yang dialami

2. Dukungan psikologis orangtua dan keluarga memberikan sumbangsih besar terhadap keberhasilan proses pembelajaran mahasiswa, hal ini akan berdampak pula pada dukungan sarana bagi terpenuhinya kebutuhan belajar.

3. Dosen terus mengingatkan dirinya sebagai untuk menjalankan peran sebagai fasilitator guna meningkatkan kelas yang interaktif dan komunikatif.

4. Dosen dengan segala upayanya, memperkaya diri dengan mengikuti pelatihan-pelatihan guna menambah keterampilan menggunakan assessment tools dan aplikasi interaktif lain yang juga menarik. Sehingga tidak monoton dengan aplikasi e-learning, zoom, google meet semata. Assessment tools yang dimaksudkan seperti: google form, formLink, Quizzziz dan Quizlet. Perangkat tersebut tidak 
hanya membantu dosen tapi juga membantu mahasiswa menyelesaikan tugas ataupun kuis pada saat pembelajaran berlangsung, sehingga meminimalisir tunggakan tugas. Sedangkan aplikasi interaktif lain yang juga dapat dipelajari seperti Slido dan Mentimeter.

\section{DAFTAR PUSTAKA}

Agustina, P., Bahri, Syaiful, Abu Bakar. (2019). Analisis faktor penyebab terjadinya kejenuhan belajar pada siswa dan usaha Guru BK untuk mengatasinya. Jurnal Ilmiah Mahasiswa Bimbingan dan Konseling, Volume 4 Nomor 1 Tahun 2019, Maret, Hal 96 - 102.

Hidayat, Reja. (2020, 10 September). Stres, Burnout, Jenuh: Problem Siswa Belajar Daring Selama COVID-19. Tirto,id. Diakses dari https://tirto.id/f3ZZ

Oktaviyanthi, Rina. (2021). Korelasi Personalisasi Belajar, Akselerasi Belajar Dan Kemandirian Belajar: Suatu Studi Pendahuluan. Implementasi Dan Problematika Merdeka Belajar. Tulungagung: Akademia Pustaka.

Slivar, B. (2001). The Syndrome of Burnout, Self Image, and Anxiety With Grammar School Student. Horizons of Psychology, 10, 2, 21-32.

Tokan, K. Moses. (2021, April). Hasil Evaluasi Perkuliahan Daring FKIP Undana (Semester Genap 2020/2021 yang sedang berjalan). 
146 | Akademisi dalam Lingkaran Daring 


\title{
PENDIDIKAN JASMANI DAN PERSOALAN OLAHRAGA NASIONAL
}

\author{
Dr. Gumilar Mulya, M.Pd. ${ }^{20}$ \\ (Jurusan Pendidikan Jasmani, FKIP Universitas \\ Siliwangi)

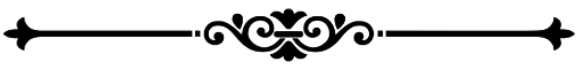

"Pergeseran pola hidup dari banyak pekerjaan yang dilakukan dengan dinamis menjadi jarang dilakukan disinyalir sebagai penyebab menurunnya status kesegaran jasmani seseorang karena kemajuan IPTEK"

Terdapat 13 persoalan olahraga secara nasional 1 mulai dari rendahnya kebugaran jasmani sampai pada kurangnya sinergi antar organisasi olahraga. partisipasi masyarakat berolahraga Indonesia hanya $34 \%$, tingkat keaktifan olaharaga siswa hanya 5 persen.

${ }^{20}$ Penulis adalah Penulis lahir di Bandung, pada tanggal 01 Januari 1967. Saat ini tercatat sebagai Dosen pada Jurusan pendidikan jasmani, FKIP Universitas Siliwangi, dengan mengampu mata kuliah Dasar-Dasar Pendidikan Jasmani, Tenis, Pendidikan Kesehatan, Olahraga Petanque, Pendidikan Kepramukaan dan Kewirausahaan Olahraga.. Menyelesaikan pendidikan S1 pada jurusan Pendidikan Kesehatan dan rekreasi, FPOK IKIP bandung (1986), melanjutak S2 ke UNESA Surabaya (angkatan pertama 1997) dan S3 di universitas Negri Jakarta (2014). Profesi kepelatihan olahraga diperoleh tahun 2002 sebagai pelatih Nasional Tenis Tingkat Mahasiswa dan tahun 2018 sebagai Pelatih Internasional Level 1 Olahraga Petanque yang dikeluarkan lah FIJP di perancis. Menjadi Instruktur PLPG Sertifikasi Guru tahun 2007-2014. 
Secara bertahap pemerintah melalui KEMENPORA berharap akan ada peningkatan di tahun 20212024sebesar $40 \%$ hingga idealnya70\% untuk mendapatkan talenta-talenta yang baik melalui partisipasi masyarakat berolahraga. Tingkat keaktifan peserta didik ditargetkan naik hingga mencapai $10 \%$. Kunci keberhasilan pemecahan persoalan olahraga diawali pada pembudayaan olahraga dimana di dalamnya adalah kesadaran dan tanggung jawab orang tua dalam keluarga untuk membiasakan keluarga gemar melakukan olahrga dan pelaksanaan pembelajaran pendidikan Jasmnai, Olahraga, dan Kesehatan (PJOK) di sekolah.

\section{Persoalan Olahraga Nasional}

Program pemerintah tahun 2019-2024 adalah di fokuskan pada pembangunan inprastruktur, pembangunan sumber daya manusia, pengembangan investasi, reformasi birokrasi, dan penggunaan APBN yang fokus dan tepat sasaran. Guna mewujudkan program tersebut, Kementrian Pemudan dan Olahraga sebagai salah satu kementrian yang menangani Keolahragaan dan Kepemudaan melakukan upayauapaya untuk mewujudkan program tersebut. Berdasarkan pemetaan Kementerian Pemuda dan Olahraga (KEMENPORA) Republik Indonesia yang disampaikan pada Rapat kerja dengan Komisi X DPR RI tanggal 23 Maret 2018 dan disampaikan lagi pada rapat terbatas yang dipimpin langsung Presiden Joko Widodo di Istana Negara, Jakarta tanggal 15 Maret 2021,dijelaskan hasil pemetaan terdapat 13 permasalahan olahraga secara nasional sebagai berikut: 1. partisipasi dan kebugaran jasmani masyarakat;2. prasarana dan sarana;3. sistem pembinaan olahraga prestasi; 4. manajemen kompetisi; 5 . tenaga keolahragaan; 6. sport science; 7. dukungan anggaran; 8. 
manajemen organisasi keolahragaan; 9. profesi sebagai olahragawan belum sepenuhnya menjadi pilihan; 10 . kurikulum Pendidikan Khusus Atlet; 11. data base,;12. peran BUMN dan Pemerintah Daerah; dan 13. Sinergi organisasi keolahragaan. Dari ke 13 permasalahan tersebut, pembahasan lebih lanjut hanya difokuskan pada masalah pertama, karena semua permasalahan diawali dari kurangnya kesadaran masyarakat berpartisipasi pada kegiatan olahraga.

\section{Partisipasi Masyarakat Berolahraga}

Berdasarkan Sensus Penduduk tahun 2020, jumlah penduduk Indonesia hingga Desember 2020 mencapai 271.349.889 jiwa. Sementara menurut MENPORA angka partisipasi masyarakat Indonesia terhadap kegiatan olahraga sebesar $34 \%$ berarti baru 92.258 .962 masyarakat yang aktif berpartisipasi dalam kegiatan olahraga, target KEMENPORA di tahun 2024 diharapkan mencapai $70 \%$ penduduk Indnesia berartisipasi aktif dalam kegiatan olahraga.Pencapaian $70 \%$ angka partisiapasi yang ditargetkan memerlukan kerja keras dan partisipasi serta kesadaran dari seluruh komponen bangsa, dan garda terdepan untuk mewujudkan hal tersebut adalah di keluarga dandi sekolah.Model pembinaan olahraga jangka panjang sebagaimana dikemukakan Bompa, dan Buzzichelli, (2019:42) dan Joko Pekik (2012) tahapan usia olahraga dimulai pada masa anak-anak, atlet junior sebagai emasalan hingga terwujud atlet berprestasi. Masa anak-anak merupakan sebuah periode pengembangan multilateral, yang merupakan dasar dari program latihan. Bagian dari program latihan ini termasuk perkembangan motorik multifase, keterampilan multisport, dan beberapaketerampilan khusus olahraga. Variasi latihan yang dilakukan anak selama waktu ini memungkinkanuntuk pengembangan penuh sistem 
fisiologis anak. Misalnya, dalam fase latihan ini sistem neuromuskuler, kardiovaskular, dan energi diaktifkan dengan berbagai cara untukmemungkinkan perkembangan yang seimbang. Ketika perkembangan atlet mencapai tingkat yang dapat diterima,terutama perkembangan fisiknya, dia akan maju ke fase perkembangan kedua yang ditandai dengan tingkat spesialisasi yang lebih tinggi.

Djoko Pekik (2004: 4-5) menjelaskan bahwa pergeseran pola hidup dari banyak pekerjaan yang dilakukan dengan dinamis menjadi jarang dilakukan disinyalir sebagai penyebab menurunnya status kesegaran jasmani seseorang karena kemajuan IPTEK. Seseorang dengan tingkat kesegaran jasmani yang baik maka orang tersebut akan dapat melakukan aktivitas sehari-hari dengan waktu yang relatif lama, dibanding dengan mereka yang tingkat kesegaran jasmaninya rendah. Berdasarkan survei WHO dengan mengumpulkan 1,6 juta siswa di 146 negara dan wilayah antara tahun 2001 dan 2015, ditemukan bahwa 81 persen remaja berusia antara 11 dan 17 tidak melakukan aktivitas fisik dengan intensitas ringan hingga sedang setidaknya satu jam sehari. Aktivitas yang dimaksud antara lain adalah berjalan, mengendarai sepeda, atau berolahraga. Data yang dikemukakan ae/rap, AFP, Reuters (29.11.2019) terdapat empat dari setiap lima remaja tidak memetik nikmat dan manfaat kesehatan sosial, fisik, dan mental dari aktivitas fisik sehari-hari.

Kondisi tersebut diperparah dengan pandemi Corona Virus Diseasepada tahun 2019 (COVID 19)di berbagai negara termasuk Indonesia. Peserta didik biasanya minimal mengikuti pelajaran PJOK satu kali dalam seminggu ditambah tugas di luar kegiatan intrakurikuler. Sampai tulisan ini dibuat, pembalajaran 
PJOK dilakukan dengan sistem Daring (dalam Jaraingan) melaui sistem sincronous tatap maya maupun a syncrous baik mandiri maupun kolaboratif.Kalaupun ada beberapa sekolah yang melaksanakan pembeajaran PJOK secara Luring (Luar Jaringan) dilakukan secara bergantian dan materi yang diberikan sangat terbatas sehingga kurang dapat mengembangkan potensi peserta didik akan kebutuhan gerak.

Dampak dari kurang gerak pada masa anak-anak dapat menjadi kebiasaan ketika mengnjak masa remaja bahkan sampai dewasa. Tidak heran jika data WHO menunjukan usia remaja 11-17 tahun tidak melakukan aktifitas olahraga yang ringan sekalipun. Sudah banyak data yang menunjukan dampak dari budaya kurang gerak atau pola hidup sedenter dapat menimbulkan penyakit degeneratif seperti penyakit jantung koroner dan diabetes militus.

\section{Sistem Pembinaan Olahraga Prestasi}

Ketika menjabat sebagai Deputi Peningkatan Prestasi, Joko Pekik (2012) dalam beberapa pertemuan ilmiah sering menayangkan "Bangunan Sistem Keolahraga Nasional”. Sebagai fondasi dari sistem tersebut terletak pada "keluarga" kemudian di dilanjutkan "pemasalana" melalui olahraga rekreasi, olahraga pendidikan dan olahraga tradisional termasuk klub olahraga usia dini. Tahap selanjutnya anak-anak ataupesrta didik yang memiliki bakat dalam olahraga ditingkatkan pembinaanya secara lebih khusus melalui PPLP/PPLM, Klub-Klub, PP/PB, Sentra Pembinaan di TNI/POLRI atau KORPRI. Setelah di seleksi lagi lahirlah squad atlet andalan hingga atlet kalinber dunia. Berdasarkan bangunan olahraga nsasional tersebut.

Di lapangan khususnya di daerah, masih banyak pola pembinaan tidak dilakukan secara sitematis, Pendidikan 
Jasmani di sekolah dianggap tidak penting, guru-guru mata pelajaran lain sering bersikaf apatis terhadap paeserta didik yang memiliki prestasi olahraga dan sering meminta ijin mengikuti kejuaraan, klub olahraga junior sering didominasi orang tua yang ingin cepat anaknya menjadi juara, prasarana dan sarana seadanya, kualifikasi pelatih masih belum merata. Tidak sedikit anak yang potensial pada usia dini di cabang olahraga tertentu, memasuki usia remaja prestasinya malah menurun. Faktornya banyak, seperi perubahan hormon pada amsa remaja membuat ingin berpenampilan menarik sementara kalau olahraga terus muka jadi hitam, tidak ada waktu untuk bermain dengan temanteman seusia remaja lainnya yang tidak terlibat dalam olahraga, dukungan orang tua yang menurun karena prestasi anaknya tidak meningkat sehingga malu samm orang tua lainnya, Di sekolah, ketika musim penerimaan siswa baru dibuka jalur prestasiolahraga, ketika sudah diterima sulit mendapat dukungan guru mata pelajaran lain.

Sistem pembinaan olahraga prestasi khususnya harus dilaksanakan sedini mungkin, dengan memperhatikan perkembangan anak dan menerapkan prinsip "multilateral development", guna menghindari kejenuhan dalam berlatih dan memerkaya pengalaman gerak dari berbagai cabang olahraga yang ditekuninya. Secara bertahap orang tua dan pelatih mengarahkan ke cabang olahraga yang sesuai dengan bakatnya. Perhatian sekolah, cabang olahraga dan PEMDA melalui KONI dan Pengcab/Prov harus mulai membantu kebutuhan atlet yang memiliki bakat olahraga.

\section{Kurikulum PJOK Selama Pandemi}

Undang-Undang sistem keolahragaan nasional (UUSKN) no 3 tahun 2005 pasal 17 menjelaskan bahwa ruang lingkup olahrag meliputi olahraga rekreasi, 
olahraga pendidikan dan olahraga prestasi. Jika dilihat dar prosentase jumlah penduduk, maka usia sekoal SD sampai SMA atau yang sederajat baik di lingkungan kemendikbud maupun Kemenag, merupakan jumlah masyaratkat yang sangat banyak yang dapat berpartisipasi aktif dalam kegiatan olahraga. Olahraga pendidikan dengan nama PJOK. Tujuan PJOK sebagai media untuk merangsang perkembangan jasmani, rohani, sosial dan intelektual, pada akhirnya PJOK sebagai wadah unik penyempurnaan watak, dan sebagai wahana untuk memiliki dan membentuk kepribadian yang kuat, watak yang baik dan sifat yang mulia.

Berdasarkan Lampiran Permendikbud nomor 719 tahun 2020 Tentang Pedoman Pelaksanaan Kurikulum Pada satuan pandidikan Dalam Kondisi Khusus butir D tentang pembelajaran, diantaranya dilakukan secara aktif, sesuai dengan kemampuan dan kebutuhan Peserta Didikdan menyenangkan. Satuan Pendidikan/Guru Tetap Menggunakan Kurikulum Nasional, dengan Penyederhanaan Kurikulum dalam Kondisi Khusus yang Disusun oleh Kemendikbud. Serta satuan pendidikan/Guru dapat Melakukan Penyederhanaan Kurikulum Secara Mandiri.(Keputusan Kepala Balitbang dan Perbukuan NO. 018/H/KR/2020). Pelaksanaan kurikulum Pendidikan Jasmani di masa pandemi Covid 19 dikemukakan Suherman, Adang (2020) yang membagi 5 step (tahapan): 1. Melakukan latihan secara teratur; 2Perolehan Status Kebugaran; 3. Pola Latihan Sendiri; 4 Evaluasi sendiri; dan 5 Mandiri;

Ke lima tahapan tesebut nampaknya menjadi sebuah alternatif ketika guru PJOK melaksanakan pembelajaran daring melalui a syncronous. Pada adsarnya pembelajaran jarak jauh merupakan proses belajar mandiri secara aktif berdasarkan paket belajar (modul) dengan bimbingan tutorial yang diselenggarakan dari 
jarak jauh dan satuan waktu tertentu untuk mengembangkan sikap, pengetahuan dan keterampilan sesuai dengan jenis, sifat, dan jenjang pendidikan yang telah ditetapkan. Melalui pola step demi step guru PJOK sebagai fasilitator akan lebih mudah dalam mengarahkan, memandu dan mengevaluasi kinerja peserta dididk selama belajar di rumah.

Materi pembelajaran PJOK pada masa pandemi telah di sederhanakan baik jumlah mata pelajaran maupun jam pelajaran. Sebagai contoh pada peserta didik kelas VII semester 1, dari 8 materi pelajaran cukup dilaksanakan 5 materi yaitu: aktivitasjalan cepat, bela diri pencak silat, kebugaran ajsmani, gerak berirama dan teori mengenai perkembangan tubuh remaja. Dalam rangka menanamkan budaya olahraga, materi tersebut lebih mudah dikerjakan peserta didik sekalipun di rumah, dengan tugas yang jelas diberikan, peserta didik dengan penuh gembira berusaha mengulang-ulang gerakan tertentu untuk membuat video yang terbaik, disadari atau tidak mereka sedang melakukan aktifitas gerak olahraga sesuai dengan yang diharapkan. Step demi step sesuai yang diusulkan Suherman, Adang, secara bertahap dapat dilakukan peserta didik tanpa harus merasa terpaksa.

Semuanya berpulang kepada guru PJOK sebagai ujung tombak dalam keberhasilan membuat peserta didik menggemari olahraga. Jangan memberikan pelatihan olahraga pada materi pembelajaran PJOK. Buat peserta didik gembira dan tidak merasa terpaksa membuat tugas gerak. Sadari tidak semua peserta didik berbakat menjadi atlet, mereka memiliki bakat dan citacita masing-masing. Berikan penyadaran apapun citacitanya harus ditempuh dengan kondisi tubuh yang sehat. Kondisi tubuh yang sehat akan tercapai melalui makan maknan yang bergizi seimbang, istirahat yang 
cukup dan melakuka olahraga yang rutin dan teratur, apapun jenis olahaganya. Materi yang ada di kurikulum meruakan alat untuk mencapai tujuan pendidikan secara keseluruhan. Beri penilaian yang objektif terhadap hasil kerja peserta didik. Berikan motivasi melalu reward dan funishment yang edukatif. Diharapkan melalui upaya tersebut yang diberikan pada pembelajaran PJOK, maka Penidkan Jasmani benarbenar dapat berkontribusi terhadap pencapaian olahraga prestasi nasional.

\section{DAFTAR PUSTAKA}

ae/rap (AFP, Reuters)https://www.dw.com/id/whoempat-dari-lima-remaja-di-seluruh-duniakurang-gerak-dan-olahraga/a-51454298.

Diunduh 29.11.2019

Djoko Pekik Irianto.(2004). Pedoman Praktis Berolahraga Untuk Kebugaran dan Kesehatan. Yogyakarta: Andi Offset.

https://www.kemenpora.go.id/detail/442/rakerdengan-komisi-x-dpr-ri-menpora-amalipaparkan-grand-design-olahraga-nasional

https://www.kemenpora.go.id/detail/393/mendikbuddukung-grand-design-olahraga-nasional

Peraturan Pemerintah Republik Indonesia Nomor 16 Tahun 2007 Tentang Penyelenggaraan Keolahragaan

Suherman, Adang. 2020. Perkembangan Kurikulum Penjas Dimasa New Normal Dalam Pembentukan Karakter Siswa. (More Active Peoples for Healthier Generations). PPt. Disampaikan pada Seminar Nasional Keolahragaan di Bandung bulan September 2020. 
Tudor O.Bompa,and Carlo,Buzzichelli, 2019. Periodization Theory and Methodology of Training. Sixth Edition. United States,Human Kinetics

Uwes A. Chaeruman. 2010. e-Learning Pada Pembelajaran Jarak Jauh. Pusat Teknologi Informasi dan Komunikasi Pendidikan Kementrian Pendidikan Nasional. 


\section{HIGHER ORDER THINKING SKILLS DALAM PENDIDIKAN JASMANI}

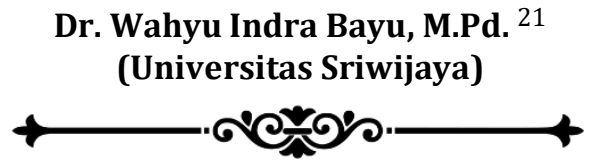

"HOTS adalah aspek penting dalam proses belajar mengajar. Dalam pendidikan jasmani, berpikir kritis memungkinkan peserta didik untuk dapat membuat keputusan yang masuk akal dan dapat dipertahankan tentang tugas atau tantangan gerakan"

Keterampilan berpikir tingkat tinggi, juga disebut keterampilan yang melampaui menghafal informasi atau menceritakan kembali dan menekankan pengembangan keterampilan analitis. Mereka yang menggunakan keterampilan berpikir tingkat tinggi (Higher Order Thinking Skills/HOTS) dapat memahami bagaimana menganalisis dan mengevaluasi informasi yang kompleks, mengkategorikan, memanipulasi, dan menghubungkan fakta, memecahkan masalah untuk

21 Penulis merupakan Dosen pada Program Studi S1 Pendidikan Jasmani dan Kesehatan dan S2 Pendidikan Olahraga FKIP Universitas Sriwijaya. Lahir dan besar di Kabupaten Jombang Jawa Timur, tepatnya di Kec. Sumobito. Menempuh pendidikan tinggi S1-S3 di Universitas Negeri Surabaya dari tahun 2005-2015. 
solusi, memahami konsep, koneksi, dan memikirkan gambaran besarnya, memecahkan masalah, memunculkan ide, dan mengembangkan penalaran yang berwawasan. HOTS adalah aspek penting dalam proses belajar mengajar. Kemampuan berpikir seseorang dapat mempengaruhi kemampuan, kecepatan, dan efektivitas belajar. Oleh karena itu, kemampuan berpikir sangat berkaitan dengan proses pembelajaran. Peserta didik yang dilatih untuk berpikir menunjukkan dampak positif bagi perkembangan pendidikannya. Keterampilan berpikir tingkat tinggi adalah konsep yang mencatat tentang berbagai jenis pembelajaran dan perbedaan dalam jumlah pemrosesan kognitif. Ini adalah cara untuk membantu siswa berpikir dan tidak hanya menghafal tetapi juga meningkatkan kemampuan kognitif mereka.

Pemikiran tingkat tinggi adalah konsep reformasi pendidikan berdasarkan taksonomi pembelajaran (seperti taksonomi Bloom). Dasar implementasi HOTS dalam pembelajaran adalah bahwa beberapa jenis pembelajaran membutuhkan lebih banyak pemrosesan kognitif daripada yang lain, tetapi juga memiliki manfaat yang lebih umum. HOTS merupakan konsep yang sudah populer dalam pendidikan di Amerika. HOTS membedakan keterampilan berpikir kritis dari hasil belajar tingkat rendah, seperti yang dicapai dengan menghafal. HOTS adalah konsep yang mencatat tentang berbagai jenis pembelajaran dan perbedaan dalam jumlah pemrosesan kognitif. Ini adalah cara untuk membantu peserta didik untuk berpikir dan tidak hanya menghafal, tetapi juga meningkatkan kemampuan kognitif mereka. HOTS meliputi sintesis, analisis, penalaran, pemahaman, penerapan, dan evaluasi (dalam taksonomi Bloom). 
HOTS meliputi pembentukan konsep, koneksi antar konsep, mendapatkan gambaran besar, visualisasi, pemecahan masalah, membuat pertanyaan, menggeneralisasi ide, berpikir kritis, pemikiran/penerapan praktis, dan berpikir kreatif. Dalam pendidikan jasmani, berpikir kritis merupakan salah satu tujuan yang harus dikembangkan atau dicapai dalam pembelajaran. Berpikir kritis dalam pembelajaran pendidikan jasmani memungkinkan peserta didik untuk dapat membuat keputusan yang masuk akal dan dapat dipertahankan tentang tugas atau tantangan gerakan (McBride, 2016). Para pemikir kritis yang sukses dalam olahraga, misalnya, mampu menerapkan keterampilan motorik yang dipelajari secara strategis serta untuk mengembangkan kebiasaan aktivitas fisik (Lodewyk, 2009).

Berpikir kritis adalah cara berpikir yang digunakan untuk meningkatkan kualitas pemikirannya dengan menganalisis, menilai, dan merekonstruksinya secara terampil. Berpikir kritis adalah apa yang kita bicarakan ketika kita ingin peserta didik kita menjadi seseorang yang evaluatif, kreatif, dan inovatif. Keterampilan yang kita butuhkan untuk dapat berpikir kritis bermacammacam meliputi observasi, analisis, interpretasi, refleksi, evaluasi, inferensi, penjelasan, pemecahan masalah, dan pengambilan keputusan. Berpikir kritis adalah kemampuan untuk membuat keputusan yang tepat dengan mengevaluasi beberapa sumber informasi yang berbeda secara objektif. Dengan demikian, para pemikir kritis memiliki banyak keterampilan penting lainnya, termasuk analisis, kreativitas, pemecahan masalah, dan empati.

Gerakan yang mahir dalam pendidikan jasmani melibatkan keterampilan pengambilan keputusan yang baik seperti berpikir kritis. Misalnya, peserta didik yang 
belajar sepak bola menghadapi banyak keputusan tentang aturan, strategi, taktik, dan keterampilan. Keputusan ini termasuk transisi dari bertahan ke menyerang ataur sebaliknya, serta Gerakan yang melibatkan postur tubuh untuk mengatasi pola permainan dari lawan. Peserta didik yang berhasil adalah yang dapat mengidentifikasi dan memahami masalah, memutuskan bagaimana menindaklanjutinya, dan kemudian mengevaluasi sumber umpan balik internal dan eksternal (misalnya, guru, perbandingan teman sebaya). Sebagai perbandingan, pesrta didik yang kurang berhasil dala proses belajar cenderung terlalu bergantung pada guru untuk mendapatkan informasi, dan dukungan emosional (King \& Kitchener, 2002), sebagian karena mereka memandang guru sebagai satusatunya sumber pengetahuan. Akibatnya, mereka sering gagal bertahan saat mengerjakan tugas atau tidak cukup menggunakan sumber pengetahuan lain seperti rekanrekan terampil atau literatur (Cothran \& Kulinna, 2006).

Keterampilan berpikir kritis inti meliputi analisis, interpretasi, inferensi, evaluasi, penjelasan, dan refleksi diri. Keterampilan ini sangat penting dalam pemecahan masalah dan pengambilan keputusan dalam berbagai konteks yang sangat luas dan di semua tingkat pendidikan dan profesional. Kita menggunakannya setiap hari, dan kita dapat terus meningkatkannya. Kemampuan untuk berpikir kritis tentang suatu masalah untuk menganalisis pertanyaan, situasi, atau masalah hingga ke bagian paling dasar adalah yang membantu kita mengevaluasi keakuratan dan kebenaran pernyataan, klaim, dan informasi yang kita baca dan dengar. Pembelajaran pendidikan jasmani yang dipersiapkan dengan baik, meskipun hanya dengan pendekatan bermain terbukti efektif dapat meningkatkan kemampuan berpikir kritis pesrta didik kelas IV Sekolah Dasar (Bayu et al., 2013). Olahraga 
dengan tingkat intensitas sedang yang dilakukan secara teratur dan konsisten dapat membantu menigkatkan fungsi otak dalam hal kemampuan proses berpikir (Bidzan-Bluma \& Lipowska, 2018; Donnelly et al., 2016; Ploughman, 2008).

Mengapa kita harus mengajarkan pemikiran kritis dalam pendidikan jasmani? Pertama, pemahaman untuk menjadi manusia yang secara alami mampu untuk berpikir tidak hanya dapat dilakukan dengan berpikir secara rasional, tetapi juga diperlukan pemikiran kritis dengan mempelajaran konten akademik (pendidikan). Manusia membutuhkan "latihan" yang ekstensik untuk dapat mengembangkan dan meningkatkan kemampuan berpikirnya. Hal ini digunakan untuk menghindari terjasinya penggunaan pemikiran instingtual, pemikiran spontan, egosentris yang rentan terhadap informasi keyakinan yang irasional. Pemikiran yang seperti ini cenderung mementingkan diri sendiri dan meminimalkan kaspasitas kita untuk berempati atau masuk pada sudut pandang diri kita sendiri, dan tidak bersikap adil terhadap sudut pandang orang lain.

Berpikir kritis adalah kemampuan penting untuk dibina dalam pendidikan jasmani untuk memfasilitasi peningkatan pengetahuan, penalaran, dan pembelajaran mandiri peserta didik. Pembelajaran pendidikan jasmani dapat memupuknya dengan menyediakan lingkungan yang merangsang keterampilan gerak yang dapat melibatkan peran pengetahuan dan keyakinan pada pembelajaran dan pemodelan pemikiran kritis, serta memberikan dukungan yang memadai kepada peserta didik dan memberikan tugas yang lebih terbuka. Selain membantu peserta didik secara motivasi dan mental, pembelajaran pendidikan jasmani dapat menumbuhkan pemikiran kritis dalam pendidikan jasmani juga dapat memberi mereka cara berpikir yang 
lebih baik sehingga mereka dapat menerapkan resolusi tantangan yang akan mereka hadapi dalam mata pelajaran akademik lain dan dalam kehidupan.

\section{Daftar Pustaka}

Bayu, W. I., Suroto, \& Maksum, A. (2013). Play-Based Learning to Enhance Critical Thinking Capabilities. Anima, 28(2), 96-103.

Bidzan-Bluma, I., \& Lipowska, M. (2018). Physical activity and cognitive functioning of children: A systematic review. In International Journal of Environmental Research and Public Health (Vol. 15, Issue 4). MDPI AG. https://doi.org/10.3390/ijerph15040800

Cothran, D. J., \& Kulinna, P. H. (2006). Students' perspectives on direct, peer, and inquiry teaching strategies. Journal of Teaching in Physical Education, 25(2), 166-181. https://doi.org/10.1123/jtpe.25.2.166

Donnelly, J. E., Hillman, C. H., Castelli, D., Etnier, J. L., Lee, S., Tomporowski, P., Lambourne, K., Szabo-reed, A. N., Ed, D., Co-chair, F., Hillman, C. H., Co-chair, P. D., Ph, D., Etnier, J. L., Ph, D., Lee, S., Ph, D., Tomporowski, P., Ph, D., ... Szabo-reed, A. N. (2016). Physical activity, fitness, cognitive function, and academic achievement in children: A systematic review. In Medicine and Science in Sports and Exercise (Vol. 48, Issue 6). Lippincott Williams and Wilkins. https://doi.org/10.1249/MSS.000000000000090 1 
King, P. M., \& Kitchener, K. S. (2002). The Reflective Judgment Model: Twenty years of research on epistemic cognition. In B. K. Hofer \& P. R. Pintrich (Eds.), Personal epistemology: The psychology of beliefs about knowledge and knowing (pp. 37-61). Lawrence Erlbaum Associates Publishers. https://psycnet.apa.org/record/2001-18187-002

Lodewyk, K. R. (2009). Fostering Critical Thinking in Physical Education Students. Journal of Physical Education, Recreation \& Dance, 80(8), 12-18. https://doi.org/10.1080/07303084.2009.105983 68

McBride, R. E. (2016). Critical Thinking-An Overview with Implications for Physical Education. Journal of Teaching in Physical Education, 11(2), 112-125. https://doi.org/10.1123/jtpe.11.2.112

Ploughman, M. (2008). Exercise is brain food: The effects of physical activity on cognitive function. Developmental Neurorehabilitation, 11(3), 236240.

https://doi.org/10.1080/17518420801997007 
164 | Akademisi dalam Lingkaran Daring 


\title{
MOTIVASI DAN KEPERCAYAAN DIRI DALAM MELAKUKAN AKTIVITAS FISIK MELALUI PEMBELAJARAN DARING
}

\author{
Pinton Setya Mustafa, M.Pd ${ }^{22}$ \\ (Universitas Islam Negeri Mataram)

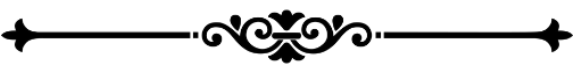

"Pembelajaran daring memberikan tren serta warna baru dalam model pembelajaran yang terintegrasi. Kepercayaan diri dan motivasi sangat diperlukan dalam pembelajaran daring bagi peserta didik, sebab mereka melakukan aktivitas kegiatan belajar dari tugas-tugas secara online tanpa berdekatan langsung dengan pendidik" $^{\prime \prime}$

Dada perkembangan pembelajaran di era industri 4.0 ini terjadi pergeseran yang cukup signifikan, dimana metode serta informasi dan sumber belajar tersedia secara luas melalui berbagai media, diantaranya: media cetak, elektronik, audio, video, internet, dan sumber lain yang dapat diakses. Dengan terjadinya fenomena tersebut, mengakibatkan pola pendidikan di Indonesia

22 Penulis lahir di Tulungagung, 04 Agustus 1992, penulis merupakan Dosen Pendidikan Jasmani dan Kesehatan di Universitas Islam Negeri Mataram, penulis menyelesaikan gelar Sarjana pada Program Studi Pendidikan Jasmani dan Kesehatan di Universitas Negeri Malang (2016), kemudian gelar Magister Pendidikan diselesaikan di Universitas Negeri Malang pada Program Studi Pendidikan Olahraga (2019). 
melahirkan tema pada Hari Pendidikan Nasional pada 02 Mei 2021 "Serentak Bergerak Wujudkan Merdeka Belajar". Dalam merdeka belajar, peserta didik dengan bebas dapat mengakses informasi dan sumber belajar tanpa ada hambatan dan kendala dari sisi ruang dan waktu, selain itu guru juga tidak dipusingkan dengan administrasi pembelajaran yang rumit dan tidak fungsional (Mustafa, 2021: 157). Walaupun pembelajaran terjadi di tengah pandemi COVID-19 ini, kualitas pembelajaran tetap terjaga dengan baik dan mampu membentuk output sumber daya manusia (SDM) yang unggul dan berdaya saing. Sudah satu tahun lebih pembelajaran tatap muka tidak dapat dilakukan sebagaimana mestinya di sekolah, sehingga dalam kurun waktu ini pembelajaran dilakukan lebih banyak menggunakan dalam jaringan (daring). Banyak terjadi perselisihan dengan pembelajaran daring tersebut. Salah satu dari segi positif adalah dapat menghemat waktu, biaya, dan tenaga serta memperluas jaringan pembelajaran. Namun dari segi negatifnya hubungan sosial dan psikis peserta didik akan terganggu jika tidak mampu mengikuti pola pembelajaran daring tersebut. Perlu adanya monitoring, refleksi dan evaluasi agar hambatan dan kendala yang terjadi selama pembelajaran daring dapat berjalan dengan optimal, walaupun masih ada aspek yang tidak tergantikan dari pembelajaran tatap muka.

Pembelajaran daring atau yang dikenal dengan pembelajaran online atau e-learning yang menggunakan jaringan internet dapat sukses apabila didukung oleh: (1) infrastruktur yang memadai; (2) sumber daya pendidik yang profesional dan kompeten; (3) regulasi yang baik; (4) sistem informasi yang berkualitas; (5) berkualitas satuan pendidikan, yaitu: sekolah maupun perguruan tinggi; (6) dan metode pembelajaran yang tepat (Pangondian et al., 2019: 59). Kondisi saat ini di 
Indonesia sedang meningkatkan keenam aspek tersebut, jadi untuk membangun pembelajaran daring yang baik tidak hanya dipengaruhi oleh satu atau dua faktor saja. Namun hal tersebut bukan menjadi alasan bahwa menyalahkan kondisi yang belum memadai jika dilakukan pembelajaran daring. Jika terus menunggu semuanya standar tentunya tidak ada progres secara bertahap dalam menerapkan pembelajaran daring di tengah pandemi COVID-19 ini. Sarana dan prasarana memadai merupakan hal pokok yang harus dipenuhi dalam pembelajaran daring agar interaksi antara pendidik dan peserta didik dapat diakses dengan lancar (Handarini \& Wulandari, 2020: 502). Di zaman sekarang selama tidak berada di daerah tertinggal, jarang ditemukan alasan bahwa pendidik maupun peserta didik tidak memiliki device (laptop atau smartphone) dalam pembelajaran daring. Selain itu pemerintah juga memberikan bantuan kuota internet bagi pendidik dan peserta didik selama pembelajaran via daring. Sedangkan yang berada di daerah tertinggal, pemerintah juga berupaya membangun jaringan komunikasi yang dapat terhubung secara online dan terintegrasi sebagai peningkatan teknologi, informasi, dan komunikasi (TIK) abad 21. Selanjutnya kemandirian peserta didik akan terbentuk secara kreatif, inovatif, dan kritis dalam memperoleh ilmu pengetahuan selama mengikuti pembelajaran daring, karena tidak dibatasi oleh tempat dan waktu (Syarifudin, 2020: 33).

Pembelajaran daring memberikan tren serta warna baru dalam model pembelajaran yang terintegrasi, akan tetapi tujuan pembelajaran daring dapat tercapai apabila peserta didik mendukung secara penuh dalam kegiatan belajar mengajar (KBM). Pembelajaran tatap muka masih menjadi pilihan utama peserta didik sebagai metode yang paling disukai, dengan alasan 
bahwa materi lebih mudah dipahami (Ningsih, 2020: 131). Kurangnya pemahaman peserta didik dalam pembelajaran daring dapat disebabkan oleh faktor internal maupun faktor eksternal. Motivasi merupakan salah satu faktor internal yang dapat mempengaruhi peserta didik dalam semangat belajar, sehingga mereka akan berusaha untuk memahami materi pembelajaran secara sukarela, tanpa ada paksaan dan tekanan dari pendidik. Adapun penyebab minimnya motivasi pada peserta didik antara lain: pembelajaran yang kurang menarik atau monoton, fasilitas pendidikan dan pembelajaran yang kurang memadai, dan kurangnya ikatan sosial pada pendidik dan peserta didik (Perdana, 2019: 84). Dalam tantangan global saat pandemi COVID19 ini salah satu yang dapat menjadi alternatif pilihan untuk mentransfer ilmu melalui pembelajaran daring. Oleh sebab itu, peran pendidik dalam menumbuhkan motivasi belajar kepada peserta didik menjadi aspek utama yang perlu dilakukan. Salah satu indikator peserta didik memiliki motivasi adalah mereka dapat percaya diri dalam melakukan tugas belajar yang diberikan (Fitriyani et al., 2020: 172).

Percaya diri merupakan sikap yang tidak mudah terpengaruh kepada orang lain dan mereka percaya bahwa yang dilakukan itu benar dan terbaik baginya (Goel \& Aggarwal, 2012: 91). Salah satu yang menjadi dasar agar peserta didik mampu membentuk pengetahuan secara mandiri adalah dengan memiliki rasa percaya diri yang tinggi dalam belajar (Safitri \& Widjajanti, 2019: 2). Selain itu, keterampilan pemecahan masalah dalam pembelajaran yang melibatkan siswa dipengaruhi oleh rasa percaya diri (Pajares \& Miller, 1994: 193). Dengan memiliki kepercayaan diri yang tinggi akan menumbuhkan motivasi yang besar pula dalam KBM (Perdana, 2019: 86). Kepercayaan diri dan motivasi sangat diperlukan 
dalam pembelajaran daring bagi peserta didik, sebab mereka melakukan aktivitas kegiatan belajar dari tugastugas secara online tanpa berdekatan langsung dengan pendidik. Pendidikan jasmani, olahraga, dan kesehatan (PJOK) merupakan salah satu mata pelajaran yang dilakukan secara daring selama pandemi COVID-19 ini. Ciri khas dari pelajaran ini adalah melibatkan siswa untuk beraktivitas menggunakan fisik mereka untuk mencapai tujuan integral pendidikan yaitu: afektif, kognitif, dan psikomotor.

Tubuh manusia perlu pemeliharaan kesehatan dan kebugaran melalui aktivitas fisik yang tepat sesuai dengan kemampuan fisik dan porsi tertentu berdasarkan karakteristik masing-masing individu (Sahabuddin \& Hakim, 2020: 39). Dengan adanya mata pelajaran PJOK di sekolah, maka dapat memberikan kesempatan bagi peserta didik untuk melakukan aktivitas fisik sesuai dengan prinsip-prinsip pemeliharaan tubuh yang sehat dan bugar. Dalam masa pandemi COVID-19 ini pembelajaran PJOK dilakukan dengan daring, sehingga pola pembelajaran yang biasanya dapat dilakukan bersama-sama di lapangan masih belum dianjurkan kembali. Sebenarnya pembelajaran daring ini dapat memberikan pengalaman yang berharga untuk membiasakan pola pembelajaran selain tatap muka di masa depan (Jamaluddin et al., 2020: 8). Kendala yang terjadi dalam pembelajaran PJOK melalui daring salah satunya adalah menurunnya motivasi belajar sehingga mereka kurang percaya diri dalam melakukan instruksi tugas aktivitas fisik, sebab setiap peserta didik memiliki kondisi yang berbeda di tempat tinggal mereka masing-masing (Febriyanto, 2021: 10). Padahal dengan kurangnya porsi individu dalam melakukan aktivitas fisik dapat mempengaruhi pemeliharaan kesehatan mereka (Dwidiyanti et al., 2016: 54). Dalam menumbuhkan motivasi belajar dan 
percaya diri kepada peserta didik untuk beraktivitas fisik adalah dengan cara melakukan analisis kondisi setiap peserta didik masing-masing. Kemudian memberikan mereka keleluasaan dalam berkreasi secara mandiri, sukarela, dan aman ketika melakukan aktivitas fisik di rumah. Keterbatasan fasilitas yang beragam menjadi tantangan pendidik dalam merancang pembelajaran daring yang membuat peserta didik termotivasi dan percaya diri untuk beraktivitas jasmani sehari-hari.

\section{DAFTAR PUSTAKA}

Dwidiyanti, P., Meidiana, P., \& Muin, M. (2016). Konseling Manajemen Diri: Metode 5 A dalam Perubahan Aktifitas Fisik Anak. Adi Husada Nursing Journal, 2 (2), 53-56.

Febriyanto, A. (2021). Survei Minat Siswa dalam Mengikuti Pembelajaran Jaringan (Daring) pada Pembelajaran Pendidikan Jasmani Olahraga dan Kesehatan di SMP Islam Az Zamir Kota Tangerang. JP3M, 2(01), 1-11.

Fitriyani, Y., Fauzi, I., \& Sari, M. Z. (2020). Motivasi Belajar Mahasiswa pada Pembelajaran daring Selama Pandemik Covid-19. Jurnal Kependidikan: Jurnal Hasil Penelitian dan Kajian Kepustakaan di Bidang Pendidikan, Pengajaran dan Pembelajaran, 6(2), 165-175. https://doi.org/https://doi.org/10.33394/jk.v6i2 .2654

Goel, M., \& Aggarwal, P. (2012). A comparative study of self confidence of single child and child with sibling. International journal of research in social sciences, 2(3), 89-98. 
Handarini, O. I., \& Wulandari, S. S. (2020). Pembelajaran Daring sebagai Upaya Study From Home (SFH) Selama Pandemi Covid 19. Jurnal Pendidikan Administrasi Perkantoran (JPAP), 8(3), 496-503.

Jamaluddin, D., Ratnasih, T., Gunawan, H., \& Paujiah, E. (2020). Pembelajaran Daring Masa Pandemik Covid-19 pada Calon Guru: Hambatan, Solusi dan Proyeksi. LP2M UIN Sunan Gunung Djati, 1-10.

Mustafa, P. S. (2021). Merdeka Belajar dalam Rancangan Pembelajaran Pendidikan Jasmani di Indonesia. In A. Wijayanto, N. Indrianto, W. I. Bayu, \& T. Yono (Ed.), Integrasi Keilmuan dalam Menyongsong Merdeka Belajar (1 ed., hal. 153-160). Tulungagung: Akademia Pustaka. https://doi.org/10.31219/osf.io/z39pr

Ningsih, S. (2020). Persepsi Mahasiswa terhadap Pembelajaran Daring pada Masa Pandemi Covid19. JINOTEP (Jurnal Inovasi Dan Teknologi Pembelajaran): Kajian Dan Riset Dalam Teknologi Pembelajaran, $7(2)$, 124-132. https://doi.org/http://dx.doi.org/10.17977/um0 31v7i22020p124

Pajares, F., \& Miller, M. D. (1994). Role of self-efficacy and self-concept beliefs in mathematical problem solving: A path analysis. Journal of Educational Psychology, 86(2), 193-203. https://doi.org/10.1037/0022-0663.86.2.193

Pangondian, R. A., Santosa, P. I., \& Nugroho, E. (2019). Faktor-Faktor yang Mempengaruhi Kesuksesan Pembelajaran Daring dalam Revolusi Industri 4.0. In Seminar Nasional Teknologi Komputer \& Sains (SAINTEKS) (Vol. 1, hal. 56-60).

Perdana, F. J. (2019). Pentingnya Kepercayaan Diri dan Motivasi Sosial dalam Keaktifan Mengikuti Proses 
Kegiatan Belajar. Edueksos: Jurnal Pendidikan Sosial \& Ekonomi, 8(2), 73-87. https://doi.org/10.24235/edueksos.v8i2.5342

Safitri, R. E., \& Widjajanti, D. B. (2019). The effect of inquiry in scientific learning on students' selfconfidence. Journal of Physics: Conference Series, 1157(4), 042073. https://doi.org/10.1088/17426596/1157/4/042073

Sahabuddin, \& Hakim, H. (2020). Penerapan Latihan Model Dhin Dhon pada Klub Bolavoli di Kabupaten Bantaeng. Celebes ABdimas: Jurnal Pengabdian Kepada Masyarakat, 2(1), 32-42.

Syarifudin, A. S. (2020). Impelementasi Pembelajaran Daring untuk Meningkatkan Mutu Pendidikan sebagai Dampak Diterapkannya Social Distancing. Jurnal Pendidikan Bahasa dan Sastra Indonesia Metalingua, $5(1)$ 31-34. https://doi.org/ttps://doi.org/10.21107/metalin gua.v5i1.7072 


\title{
PERAN SPORTS PSYCHOLOGY DALAM PEMBELAJARAN PENDIDIKAN JASMANI DI MASA PANDEMI COVID 19
}

\author{
Nur Ahmad Muharram, M.Or. ${ }^{23}$ \\ (Universitas Nusantara PGRI Kediri)

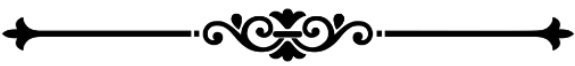

"Sports psychology berpengaruh terhadap prestasi pendidikan pembelajaran jasmani pada waktu pandemi covid 19. Upaya buat meningkatkan Sports psychology dibutuhkan untuk meningkatkan kontribusinya dalam tingkatkan prestasi pada pendidikan pembelajaran jasmani"

rtikel ini mempunyai tujuan untuk berupaya
menyajikan bermacam kajian tentang berartinya
sports psychology buat tingkatkan daya guna pendidikan
di Indonesia spesialnya pendidikan pembelajaran
jasmani. Psikologi dalam berolahraga dibutuhkan buat

${ }^{23}$ Nur Ahmad Muharram lahir di Sragen,03 September 1988, penulis merupakan Dosen Universitas Nusantara PGRI Kediri dalam bidang ilmu Pendidikan Jasmani,Kesehatan dan Rekreasi, penulis menyelesaikan gelar Sarjana S-1 PENJASKESREK di Universitas Sebelas Maret (2011),sedangkan gelar Magister Olahraga diselesaikan di Universitas Sebelas Maret, lulus pada tahun 2014, dan sekarang menempuh program Doktor pada Program Studi Ilmu Pendidikan Konsentrasi Ilmu Keolahragaan di Universitas Negeri Yogyakarta. Penulis bisa dihubungi di email: nur.ahmad1988@unpkediri.ac.id 
menunjang pelaksanaan ilmu keolahragaan buat tingkatkan prestasi pada dikala pendidikan berlangsung. Dalam bermacam riset telah menampilkan kalau sports psychology mempunyai donasi serta kedudukan nyata dalam tingkatkan prestasi belajar partisipan didik di masa pandemi covid 19. Tetapi di lndonesia sports psychology masih kurang menemukan atensi dari golongan praktisi berolahraga serta golongan di akademi besar yang mempunyai tanggung jawab buat mengelola serta meningkatkan Ilmu Psikologi yang di khususkan pada pendidikan pembelajaran jasmani di masa pandemi covid 19 ini, sehingga banyak partisipan didik yang hadapi penyusutan prestasi pada dikala pandemi covid 19 ini, sebab berdialog dengan pendidikan pembelajaran jasmani tidak luput dari pendidikan praktek, sehingga bila kedudukan sports psychology ini tidak diterapkan hingga prestasi partisipan didik hendak hadapi penyusutan pada masa pandemi covid 19. Sebagian upaya buat meningkatkan Sports psychology dibutuhkan buat tingkatkan kontribusinya dalam tingkatkan prestasi pada pendidikan pembelajaran jasmani. Antara lain merupakan:( 1) meningkatkan pemahaman kepada segala komponen yang hirau dengan prestasi pendidikan pembelajaran jasmani di masa pandemi covid 19 tentang berartinya sports psychology; serta( 2) Tingkatkan sumber energi manusia di bidang Keolahragaan.

\section{PENDAHULUAN}

Bagi (Suherman, 2018) pembelajaran jasmani merupakan sesuatu proses pendidikan lewat kegiatan jasmani yang didesain buat tingkatkan kebugaran jasmani, meningkatkan keahlian motorik, pengetahuan serta sikap hidup sehat serta aktif, kecerdasan emosi serta perilaku sportif. Pembelajaran jasmani 
didefinisikan selaku pembelajaran serta lewat gerak serta wajib dilaksanakan dengan metode metode yang pas supaya mempunyai arti untuk siswa. Pembelajaran jasmani ialah program pendidikan yang membagikan atensi yang sepadan serta mencukupi pada domaindomain pendidikan, ialah psikomotor, kognitif, serta afektif. Pembelajaran berolahraga ialah disiplin ilmu yang didominasi aplikasi pada kegiatan raga serta sedikit teori. Dalam kurikulum 2013 (K13) pembelajaran berolahraga di jenjang pembelajaran dasar menyatu dalam Mata Pelajaran Pembelajaran Jasmani Kesehatan serta Berolahraga (PJOK).

Sejalan dengan itu hingga hakikat pembelajaran jasmani mencakup seluruh faktor kebugaran, keahlian gerakan raga, kesehatan, game, berolahraga, tari serta tamasya (Qomarrullah, 2014). Pendidikan PJOK yang didominasi dengan gerakan raga dilaksanakan di ruang terbuka ataupun di lapangan. Tata cara buat pembelajaran berolahraga merupakan tata cara deduktif ataupun tata cara perintah, dengan macam pemberian tugas, demonstrasi serta sedikit uraian (Supriyadi, 2018). Bermacam keterbatasan semacam akses internet serta keahlian operasional pada fiturfitur online, pembelajaran jasmani dengan sendirinya menemui bermacam hambatan serta hambatan di masa pandemi COVID- 19.

Tujuan serta ruang lingkup sports psychology bagi( Weinberg, 2003) menegaskan kalau terdapat 2 tujuan utama mengkaji Sports psychology, ialah( 1) mengkaji pengaruh dari faktor- faktor psikologis terhadap penampilan atlet; serta( 2) mengkaji pengaruh dari keikutsertaannnya dalam kegiatan jasmani dalam meningkatkan kesehatan serta kesejahteraan. Dalam tataran yang lebih luas,( Anshel, 1990) membagikan batas kalau sports psychology merupakan ilmu yang 
menekuni sikap manusia dalam konteks berolahraga prestasi. Dalam kata lain aspek sports psychology kala berhubungan dengan prestasi dalam pendidikan pembelajaran jasmani pada masa pandemi covid 19 ini sangat mempengaruhi sebab sports psychology dalam makna luas memiliki penafsiran yang terdapat hubungannya dengan sikap partisipan didik, sehingga bila pendidikan secara daring tanpa diberikan uraian tentang berartinya sports psychology terhadap pendidikan di masa pandemi covid 19, hingga ini nanti hendak pengaruhi prestasi dari partisipan didik tersebut.

\section{PEMBAHASAN}

Penerapan pendidikan merupakan proses yang diatur sedemikian rupa bagi langkah- langkah tertentu supaya penerapan menggapai hasil yang diharapkan (Sudjana, 2010). Bagi Syaiful Bahri serta Aswan Zain (2010: 1) penerapan pendidikan merupakan sesuatu aktivitas yang bernilai edukatif, nilai edukatif memberi warna interaksi yang terjalin antara guru serta siswa. Bagi (Majid, 2014) penerapan pendidikan ialah aktivitas proses belajar mengajar selaku faktor inti dari kegiatan pendidikan yang dalam penerapannya disesuaikan dengan rambu- rambu yang sudah disusun dalam perencanaan tadinya. Bersumber pada sebagian sumber di atas, bisa disimpulkan kalau penerapan pendidikan merupakan berlangsungnya proses interaksi siswa dengan guru pada sesuatu area belajar. Bagi Majib (Majid, 2014) Rencana Penerapan Pendidikan (RPP) merupakan rencana yang menggambarkan prosedur serta pengorganisasian pendidikan buat menggapai satu kompetensi dasar yang diresmikan dalam standar isi serta sudah dijabarkan dalam silabus.

Bagi (Mulyasa, 2007) Rencana Penerapan Pendidikan (RPP) ialah sesuatu rencana yang 
menggambarkan prosedur serta menejemen pendidikan buat menggapai satu ataupun lebih kompetensi dasar yang diresmikan dalam standar isi serta sudah dijabarkan dalam silabus. Bersumber pada penjelasan tersebut bisa disimpulkaan kalau RPP ialah rencana yang terbuat oleh guru saat sebelum melakukan proses pendidikan yang mengacu pada silabus serta dipaparkan secara rinci selaku pedoman guru dikala proses pendidikan yang bertujuan menggapai tujuan pendidikan. Rencana penerapan pendidikan (RPP) ialah rencana yang menggambarkan prosedur serta menejemen pendidikan yang bertujuan buat bisa menemukan sesuatu kompetensi dasar yang diresmikan dalam standar isi yang sudah dijabarkan dari silabus. Semacam yang sudah dikemukakan oleh Permendikbud RI Nomor. 81a Tahun 2013, ialah "Rencana penerapan pendidikan merupakan rencana pendidikan yang sudah dibesarkan secara detail oleh sesuatu modul pokok ataupun tema tertentu yang mengacu pada silabus".

Bagi (Daryanto, 2014). Rencana Penerapan Pendidikan pada dasarnya ialah sesuatu wujud prosedur serta menejemen yang pembelajarannya buat menggapai sesuatu kompetensi dasar yang sudah di tetapkan dalam standar isi. Coronavirus merupakan keluarga besar virus yang menimbulkan penyakit mulai dari indikasi ringan hingga berat. Terdapat paling tidak 2 tipe coronavirus yang dikenal menimbulkan penyakit yang bisa memunculkan indikasi berat semacam Middle East Respiratory Syndrome (MERS) serta Severe Acute Respiratory Syndrome (SARS). Coronavirus Diseases 2019 (COVID-19) merupakan penyakit tipe baru yang belum sempat diidentifikasi tadinya pada manusia. Ciri serta gelaja universal peradangan COVID- 19 antara lain indikasi kendala respirasi kronis semacam demam, batuk, serta sesak nafas. Masa inkubasi rata- rata 56 hari dengan masa inkubasi terpanjang 14 hari. 
(Yurianto, Ahmad, Bambang Wibowo, 2020). Bagi (World Health Organization, 2020) COVID- 19 merupakan penyakit meluas yang diakibatkan oleh tipe coronavirus yang baru ditemui. Virus baru serta penyakit yang disebabkannya ini tidak diketahui saat sebelum mulainya wabah di Wuhan, Cina, bulan Desember 2019. COVID- 19 ini saat ini jadi suatu pandemi yang terjalin di banyak negeri di segala dunia. Penyebaran virus corona ini berakibat pada bermacam aspek tercantum ekonomi serta pembelajaran. Buat memencet jumlah penderita yang terpapar COVID- 19 pemerintah menghalangi kegiatan yang memunculkan perkumpulan massa dalam jumlah banyak tercantum bersekolah serta bekerja. Kondisi ini menyebabkan pemerintah mengambil kebijakan buat meliburkan segala kegiatan pembelajaran serta memperkenalkan alternatif proses pendidikan yang lain.

Lewat Pesan Edaran no 3 tahun 2020 pada Satuan Pembelajaran serta No 36962/ MPK. A/ HK/ 2020 tentang Penerapan Pembelajaran dalam Masa Darurat COVID- 19 hingga pemerintah memberlakukan aktivitas belajar secara daring dalam rangka penangkalan penyebaran COVID- 19 (Menteri Pembelajaran, 2020). Pandemi COVID- 19 yang terjalin di Indonesia sangat pengaruhi aktivitas belajar mengajar di sekolah dasar, sehingga aktivitas belajar mengajar yang awal mulanya dicoba dengan bertatap muka langsung di kelas wajib bergeser dengan pendidikan secara daring ataupun jarak jauh. Perihal ini pasti saja membagikan akibat pada pendidikan PJOK antara lain pendidikan PJOK yang tidak bisa terlaksana cocok dengan RPP, banyaknya partisipan didik yang meringik sebab sangat banyak tugas, serta orangtua hadapi kesusahan dalam mendampingi aktivitas belajar anak, sehingga dibutuhkan cerminan implementasi pendidikan PJOK 
pada dikala pandemi COVID- 19 supaya pendidikan bisa terlaksana lebih baik lagi.

Secara universal Bird (1986) berkata kalau kajian sports psychology, mencakup upaya- upaya tentang sikap orang yang terjalin dalam kejadian berolahraga, serta bermacam aspek psikologis yang bisa mempengaruhi terhadap sikap orang ataupun partisipan didik tersebut. (Gifford, 1991) berkata kalau topik- topik kajian sports psychology merupakan faktorfaktor psikologis yang pengaruhi karakter partisipan didik semacam: kecemasan, motivasi berprestasi, kontrol diri, imajeri, konsentrasi dim relaksasi. (Gifford, 1991) berkata kalau ruang lingkup sports psychology meliputi, penilaian sports psychology, karakter serta prestasi berolahraga, kecemasan, motivasi, agresi dalam berolahraga, dinamika kelompok, serta latihan aspekaspek kejiwaan dalam pendidikan pembelajaran jasmani. Dari penjelasan- penjelasan tersebut bisa disimpulkan kalau aspek psikologis partisipan didik pada dikala pendidikan pembelajaran jasmani pada waktu pandemi covid 19 ini sangat pengaruhi konsentrasi partisipan didik terhadap pendidikan pembelajaran jasmani, sehingga disini diperlukan motivasi- motivasi yang lebih ditunjukan pada aspek sports psychology terhadap partisipan didik. Sports psychology merupakan salah satu dari pemecahan buat menanggapi pendidikan pembelajaran jasmani pada waktu pandemi covid 19 ini sehingga prestasi dari partisipan didik tidak menyusut serta pengajar tidak senantiasa disalahkan oleh orang tua murid, sebab bila telah berdialog tentang prestasi akademik hingga ingin tidak ingin yang jadi sorotan merupakan pemangku kebijakan disekolah ialah salah satunya merupakan guru (pengajar). 


\section{KESIMPULAN}

Bersumber pada ulasan diatas tentang berartinya sports psychology terhadap prestasi pendidikan pembelajaran jasmani pada waktu pandemi covid 19 hingga alangkah baik nya kedudukan sports psychology ini lebih mencuat kala pendidikan berlangsung, sehingga dampak negatif dari pendidikan jarak jauh ini dapat di minimalisirkan. Telah jelas kalau garis besar dari pendidikan daring bertujuan membagikan layanan pendidikan bermutu secara dalam jaringan( daring) yang bertabiat masif serta terbuka buat menjangkau audiens yang lebih banyak serta lebih luas serta gampang buat dipahami oleh partisipan didik. Cocok kendan arti dari belajar jarak jauh lebih menunjuk pada pengiriman modul pendidikan kepada siapapun, dimanapun, serta kapanpun tanpa terdapat yang kesusahan ataupun terbebani dengan modul tersebut. Pendidikan jarak jauh dicoba memakai bermacam teknologi dalam area pendidikan yang terbuka, fleksibel, serta terdistribusi. Dari sebutan tersebut pendidikan terbuka serta fleksibel merujuk pada kebebasan partisipan didik dalam perihal waktu, tempat, kecepatan, isi modul, style belajar, tipe penilaian, belajar kerja sama ataupun mandiri. Kedudukan sports psychology disini bila diterapkan kedalam pendidikan yang watak nya jarak jauh, hingga dampak dari menyusutnya prestasi yang diraih oleh partisipan didik hendak menurun serta dapat meningkatkan rasa optimis, semangat didalam pendidikan berlangsung spesialnya pendidikan pembelajaran jasmani. 


\section{DAFTAR PUSTAKA}

Anshel, M. H. (1990). Psychology Sport From Theory to Practice. In Scottsdale Arizona: Gorsuch Scarisbbrick Publishers.

Daryanto. (2014). Pendekatan Pembelajaran Saintifik Kurikulum 2013. Yogyakarta: Yogyakarta: Gava Media.

Gifford, R. (1991). Applied Psychology Variety and Opportunity. Massachusets: Simon \& Schuster, Inc.

Majid, A. (2014). Implementasi Kurikulum 2013. Bandung: Bandung: Interes Media.

Mulyasa, E. (2007). Kurikulum berbasis kompetensi. Bandung.: Bandung: Rosda Karya.

Qomarrullah, R. (2014). Model Aktivitas Belajar Gerak Berbasis Permainan Sebagai Materi Ajar Pendidikan Jasmani (Penelitian Pengembangan Pada Siswa Kelas I Sekolah Dasar). Indonesian Journal of Sports Science, 1(1), 76-88.

Sudjana, N. (2010). Dasar-dasar Proses Pembelajaran. Bandung: Bandung: Sinar Baru.

Suherman, W. S. (2018). Kurikulum Pendidikan Jasmani dari Teori hingga Evaluasi Kurikulum. Retrieved May 2, 2021, from Depok: PT Rajagrafindo Persada website: https://www.google.co.id/books/edition/Penge mbangan_kurikulum_matematika/d4PAQAAMAAJ?hl=id\&gbpv=1\&bsq=Suherman,+ dkk.+(2018:+37)\&dq=Suherman, + dkk. $+(2018:+3$ 7)\&printsec $=$ frontcover

Supriyadi, M. (2018). Pelaksanaan Proses Belajar Mengajar Pendidikan Jasmani Olahraga dan Kesehatan pada Sekolah Dasar. Elanggang 
Olahraga: Jurnal Pendidikan Jasmani Dan Olahraga, 1(2), 64-73.

Weinberg, R. S. \& D. G. (2003). Foundations of sport and Exercise Psychology Ed 3rd. In USA: Human Kinetics.

WHO. (2020). Pertanyaan dan Jawaban Terkait Coronavirus. Retrieved May 2, 2021, from https://www.who.int/indonesia/news/novelcoronavirus/qa-forpublic $\% 0 \mathrm{~A}$

Yurianto, Ahmad, Bambang Wibowo, K. P. (2020). Pedoman Pencegahan dan Pengendalian Coronavirus Disease (Covid-19) (A. A. (ed. ). (M. I. Listiana Azizah, Ed.). 


\section{MODEL PEMBELAJARAN PORTOFOLIO BERBASIS MEDIA INTERAKTIF SEBAGAI ALTERNATIF PEMBELAJARAN DARING PENDIDIKAN JASMANI OLARAGA DAN KESEHATAN}

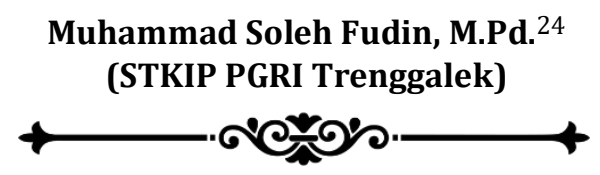

"Model pembelajaran berbasis portofolio yang merupakan inovasi pembelajaran yang dirancang untuk membantu peserta didik memahami teori secara mendalam melalui pengalaman belajar praktik-empirik sehingga akan dapat meningkatkan kemampuan belajar peserta didik."

$\mathrm{P}$ endidikan jasmani olahraga dan kesehatan merupakan mata pelajaran yang dalam pelaksanaan pendidikannya terdapat aktifitas fisik dan olahraga guna untuk mencapai tujuan pendidikan meliputi aspek

${ }^{24}$ Penulis lahir di Trenggalek, 22 Januari 1987, penulis merupakan Dosen STKIP PGRI Trenggalek pada Program Studi Pendidikan Jasmani Kesehatan dan Rekreasi, bidang ilmu Pendidikan Jasmani dan Olahraga, penulis menyelesaikan gelar SarjanaPendidikan Jasmani Kesehatan dan Rekreasi di Universitas Nusantara PGRI Kediri (2010), sedangkan gelar Magister diselesaikan di IKIP Budi Utomo Malang Program Studi Pendidikan Olahraga (2014). 
afektif, kognitif dan psikomotor. Menurut Samsudin pendidikan jasmani olahraga dan kesehatan yaitu pendidikan melalui aktivitas jasmani dengan berpartisipasi dalam aktivitas fisik, peserta didik dapat menguasai pengetahuan dan keterampilan, mengembangkan apresiasi estetis, mengembangkan keterampilan generik dan nilai sikap positif dan memperbaiki kondisi fisik untuk mencapai tujuan pendidikan jasmani. (Darmawati et al., 2017)Pendidikan jasmani olahraga dan kesehatan sesuai dengan tujuan pendidikan juga dapat membentuk watak dan karakter peserta didik. Selain itu pendidikan jasmani olahraga dan kesehatan mempunyai tujuan untuk menjaga dan meningkatkan tingkat derajat kebugaran jasmani peserta didik dengan aktivitas fisik dan olahraga. Makanya mata pelajaran pendidikan jasmani olahraga dan kesehatan dikenal sebagai dasar mata pelajaran lainnya di sekolah. Kenapa penyataan tersebut benar adanya, karena pendidikan jasmani olahraga dan kesehatan mempunyai tujuan untuk menjaga dan meningkatkan tingkat derajat kebugaran jasmani peserta didik, yang mana apabila peserta didik mencapai tingkat kebugaran yang baik maka peserta didik pasti dalam keadaan sehat jasmani. Sehingga peserta didik dalam melakukan pembelajaran mata pelajaran yang lain di sekolah dapat semangat belajar dan berfikir jernih untuk berkreativitas dan berinovasi.

Pembelajaran merupakan kegiatan inti dari proses pendidikan. Dengan melalui proses pembelajaran diharapkan dapat mencapai tujuan pendidikan dalam bentuk terjadinya perubahan tingkah laku dalam diri peserta didik. Proses pembelajaran ada karena tujuan yang hendak dicapai. Tujuan pendidikan jasmani olahraga dan kesehatan di sekolah akan tercapai apabila perencanaan, pelaksanaan dan evaluasi dalam pembelajarannya baik. Pembelajaran tidak hanya baik 
saja tapi harus berkualitas perencanaan, pelaksanaan dan evaluasi dalam pembelajarannya. Perencanaan, pelaksanaan dan evaluasi dalam pembelajaran semua dilakukan oleh seorang guru. Guru dituntut untuk kreatif dan inovatif dalam merencang, melaksanakan dan mengevaluasi agar peserta didik berminat dan bermotivasi untuk mengikuti pembelajaran dengan rasa gembira, sehingga tujuan pendidikan jasmani olahraga dan kesehatan tercapai dengan baik.

Perencanaan pembelajaran merupakan titik awal pembelajaran yang tujuannya untuk merancang desain pembelajaran agar pembelajaran berjalan dan hasil sesuai dengan tujuan pembelajaran. Dalam mendesain perencanaan pembelajaran tidak sekedar merencanakan tetapi sebelum merencanakan harus mengetahui faktor-faktor penghambat dan pendukung pembelajaran termasuk karakteristik peserta didik dan keadaan sarana dan prasarana yang ada di sekolah. Hal tersebut diketahui dengan menganalisis dari hasil pembelajaran sebelumnya dan keaadaan sekarang. Setelah mengetahui faktor-faktor tersebut, guru sebagai penanggungjawab terlaksananya pembelajaran, menentukan tujuan pembelajaran beserta indikatornya. Baru setelah itu guru mendesain perencanaan pembelajaran berdasarkan tujuan pembelajaran beserta indikatornya.

Dalam mendesain perencanaan pembelajaran pendidikan jasmani olahraga dan kesehatan harus memperhatikan aspek afektif, kognitif dan psikomotor. Guru dalam merencanakan pembelajaran, mengatur bagaimana proses pembelajaran nanti berlangsung sistematis dan teroraganisir. Agar proses pembelajaran sistematis dan teroraganisir, guru harus berfikir kreatif dan inovatif dalam menentukan strategi pembelajaran efektif dalam perencanaan pembelajaran. Sehingga guru 
dapat menggunakan waktu sacara efektif untuk mencapai tujuan pembelajaran.Dengan perencanaan pembelajaran yang berkualitas, selain dapat meminimalisir permasalahan-permasalahan yang akan muncul dalam proses pembelajaran sehingga pembelajaran berlangsung dengan baik dan keberhasilan tujuan pembelajaran akan tercapai juga.

Masa pandemi covid-19 sudah berlangsung satu tahun lebih di negeri ini. Masa pandemi covid-19 sangat berdampak pada dunia pendidikan. Pada masa pademi covid-19 ini kementrian pendidikan berinovasi dengan menetapkan beberapa kebijakan/peraturan dan program untuk mengatasi permasalahan dalam dunia pendidikan. Salah satunya kebijakan tentang pelaksanaan pembelajaran daring masa pandemi covid19. Berjalannya waktu masa pandemi covid-19 ini, banyak permasalahan-permasalahan yang muncul dalam pemberlakuaan pembelajaran daring di sekolah. Permasalahan-permasalahan tersebut diantaranya kesiapan sumber daya manusia, ketersediannya sarana internet dan perangkatnya, kesiapan peserta didik dalam pembelajaran daring. Kesiapan sumber daya manusia yaitu guru, sebagian besar belum siap karena belum terbiasa mengimplementasikan pembelajaran daring, sehingga guru masih belajar untuk mengembangkan kompetensinya. Ketersedian internet dan perangkatnya merupakan permasalahan yang juga harus segera ditangani, khususnya sekolah pinggiran yang biasanya tidak ada sinyal internet dan sarana perangkatnya masih kurang. Apalagi tingkat sekolah dasar masih banyak peserta didik atau orang tua yang belum mempunyai perangkat handphone atau laptop yang mendukung pelaksanaan pembelajaran daring. Kesiapan peserta didik dalam pembelajaran daring juga merupakan permasalahan, karena peserta didik belum terbiasa mengikuti pembelajaran daring sehingga 
peserta didik cenderung pasif dalam pembelajaran. Tetapi bagi sekolah, guru dan peserta didik yang siap melaksanakan pembelajaran daring, malah lebih termotivasi untuk belajar untuk mengembangkan kompetensinya.

Berdasarkan kebijakan dan permasalahanpermasalahan tersebut setiap sekolah dituntut untuk memanajemen pelaksanaan pembelajaran daring dengan baik, salah satunya meningkatkan sumber daya manuasia yang ada. Guru sebagai sumber daya manuasia di sekolah harus dapat mengembangkan kompetensinya dalam memanajemen proses pembelajaran daring. Salah satunya kompetensi yang harus dikembangkan yaitu merencanakan pembelajaran, karena dalam perencanaan pembelajaran daring dengan perencanaan pembelajaran luring ada perbedaannya. Dalam pembelajaran daring, peserta didik dituntut lebih aktif dalam mengembangkan kompetensinya, maka perlu desain perencanaan pembelajaran yang sesuai dengan karakteristik pembelajaran daring. Dalam desain perencanaan pembelajaran daring harus menggambarkan secara jelas dan sistematis agar peserta didik mudah memahami apa yang akan dilakukan dalam pembelajaran. Seperti pada pendidikan jasmani olahraga dan kesehatan, yang sebagian besar pembelajarannya merupakan aktivitas fisik dan olahraga, maka guru harus pintar-pintar mendesain perencanaan agar bagaimana peserta didik nanti melakukan dengan aktif pembelajarannya meskipun tidak bertatap muka.

Dalam merencanakan pembelajaran daring pendidikan jasmani olahraga dan kesehatan, guru harus menentukan model pembelajaran apa yang cocok sesuai dengan karakteristik mata ajar, peserta didik dan tujuan 
pembelajaran untuk mengembangkan strategi pembelajaran yang akan dilakukan. Model pembelajaran merupakan pola umum pembelajaran untuk mencapai tujuan pembelajaran yang diharapkan. (Khoerunnisa \& Aqwal, 2020)Menurut Bruce Joyce dan Marsha Weildalam bukunya models of teaching menyebutkan ada empat rumpun model pembelajaran yaitu (1) rumpun model pembelajaran pemrosesan informasi, (2) rumpun model pembelajaran personal, (3) rumpun model pembelajaran sosial dan (4) rumpun model pembelajaran perilaku. (Mirdad, 2020)Dari rumpun model pembelajaran tersebut masih terbagi beberapa model pembelajaran. Model model pembelajaran tersebut sangat cocok dalam pendidikan jasmani olahraga dan kesehatan, tinggal bagaimana strategi pembelajaran yang dikembangkan agar tujuan pembelajaran tercapai. Strategi yang berkaitan dengan pembelajaran yaitu (1) strategi pengorganisasian pembelajaran, (2) strategi penyampaian pembelajaran dan (3) strategi pengelolaan pembelajaran. (Gustiawati, 2017)Salah satu strategi pembelajaran yang cocok dalam pembelajaran daring yaitu pembelajaran berbasis portofolio.

Model pembelajaran berbasis portofolio yang merupakan inovasi pembelajaran yang dirancang untuk membantu peserta didik memahami teori secara mendalam melalui pengalaman belajar praktik-empirik sehingga akan dapat meningkatkan kemampuan belajar peserta didik. (Prabarini et al., 2015) Adapun langkahlangkah dalam pembelajaran berbasis portofolio yaitu (1) mengidentifikasi masalah, (2) memilih masalah, (3) mengumpulkan informasi, (4) pengembangan portifolio dan (5) penyajian portofolio. (Kokom, 2010) Aktivitas peserta didik dalam proses pembelajaran dengan menggunakan model pembelajaran praktek belajar pendidikan jasmani olahraga dan kesehatan berbasis 
portofolio dapat dilihat dari langkah-langkah pembelajarannya, dimana hampir semua langkahlangkah pembelajarannya melibatkan seluruh aktivitas kegiatan peserta didik.

Pada pembelajaran daring, pembelajaran pendidikan jasmani olahraga dan kesehatan disampaikan melalui media interaktif. Menurut (Diah \& Nita, 2018)“multimedia interaktif merupakan suatu alat yang dilengkapi dengan alat kontrol yang dapat dioperasikan oleh penggunanya dalam memilih sesuatu yang dikehendaki."Jenis-jenis model media interaktif yang digunakan untuk tujuan pembelajaran diantaranya tutorial, drill and practice, simulasi, intruksional games, hybrid, socratic, inquiry dan informasi. Dengan memanfaatkan media interaktif akan lebih efektif dan mempermudah peserta didik untuk menerima apa yang disampaikan oleh guru dalam pembelajaran. Desain model pembelajaran portofolio berbasis media interaktif pada pembelajaran daring pendidikan jasmani olahraga dan kesehatan diharapkan peserta didik lebih mudah mendapatkan informasi/petunjuk yang jelas dan dapat mendeskripsikan apa yang dilakukan saat pembelajaran. Desain model pembelajaran portofolio berbasis media interaktif dapat modifikasi sesuai dengan kebutuhan dan tujuan pembelajaran. Salah satu contoh dalam desain ini, pada saat pembelajaran sudah didesain dengan suatu informasi/petunjuk pembelajaran. Setiap informasi/petunjuk pembelajaran peserta didik melakukan kegiatan pembelajaran yang sudah disetting durasi tiap tahapan pembelajaran. Dengan apa yang dilakukan peserta didik tiap tahapan pembelajaran, peserta didik mendeskripsikan pada lembar kerja yang disampaikan di media interaktif berupa URL untuk akses, apa yang ketahui dan pahami terkait informasi yang didapat oleh peserta didik. Dengan demikian peserta didik dapat dengan mudah 
mendapatkan informasi dan mempertajam analisis dalam memahami informasi yang didapat dalam pembelajaran. $* * *$

\section{DAFTAR PUSTAKA}

Darmawati, D., Rahayu, T., \& Achmad Rifai. (2017). Leadership Guru Pendidikan Jasmani Olahraga dan Kesehatan di SMP Ogan Komering Ulu Timur Sumatera Selatan. Journal of Physical Education and Sports, 6(2), 108-116. https://journal.unnes.ac.id/sju/index.php/jpes/a rticle/view/17359

Diah, I., \& Nita, S. (2018). Pembuatan Video Sebagai Media Pembelajaran untuk Meningkatkan Pemahaman Mahasiswa. Doubleclick: Journal of Computer and Information Technology, 1(2), 6875.

Gustiawati, R. (2017). Implementasi Model-Model Pembelajaran Penjas dalam Meningkatkan Kemampuan Guru Memilih dan Mengembangkan Strategi Pembelajaran Pendidikan Jasmani Olahraga dan Kesehatan. JOSSAE : Journal of Sport Science and Education, 1(1), 27. https://doi.org/10.26740/jossae.v1n1.p27-31

Khoerunnisa, P., \& Aqwal, S. M. (2020). Analisis Modelmodel Pembelajaran. Fondatia, 4(1), 1-27. https://doi.org/10.36088/fondatia.v4i1.441

Kokom, K. (2010). Pembelajaran Kontekstual : Konsep dan Aplikasi. Bandung : Refika Aditama.

Mirdad, J. (2020). Model-Model Pembelajaran (Empat Rumpun Model Pembelajaran). Jurnal Pendidikan Dan Sosial Islam, 2(1), 1-10. 
Prabarini, I. D. A. R., Tastra, I. D. K., \& Murda, I. N. (2015). Penerapan Model Pembelajaran Berbasis Portofolio PKn Siswa Kelas V. E-Journal PGSD Universitas Pendidikan Ganesha Jurusan PGSD, 3(1), 1-10. 
192 | Akademisi dalam Lingkaran Daring 


\section{STRATEGI PEMBELAJARAN PENDIDIKAN JASMANI BERBASIS DARING DI ERA NEW NORMAL}

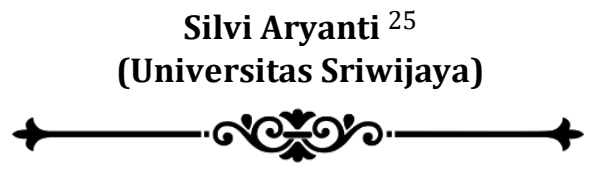

"memiliki strategi dalam pembelajaran daring di era new normal yaitu menyiapkan bahan ajar berbasis digital, menggunakan aplikasi zoom, google meet atau aplikasi

lainnya untuk pembelajaran tatap muka. Pendidik memberikan informasi pembelajaran menggunakan Whatsapp (WA) group, dan untuk pengumpulan tugas menggunakan google classroom dan email."

$\mathrm{P}$ embelajaran adanya interaksi antara peserta didik dengan pendidik dan sumber belajar di lingkungan belajar. Pendidik memberikan pembelajaran bertujuan agar dapat terjadi proses perolehan ilmu dan pengetahuan, penguasaan materi, serta pembentukan sikap kepada peserta didik. Pembelajaran membantu

25 Penulis lahir di Palembang, 21 Juli 1991, penulis merupakan Dosen Program Studi Pendidikan Jasmani, Kesehatan, dan Rekreasi Fakultas Keguruan dan Ilmu Pendidikan Universitas Sriwijaya, penulis menyelesaikan pendidikan Sarjana (S1) Pendidikan Prodi Penjaskes di FKIP Universitas Sriwijaya (2012), dan menyelesaikan pendidikan S2 di Universitas Negeri Yogyakarta Ilmu Keolahragaan Konsentrasi Pendidikan Olahraga (2015). 
peserta didik agar dapat belajar dengan baik. Pembelajaran di era sekarang dilakukan tidak secara tatap muka di kelas.

Hal ini sesuai dengan Keputusan Menteri Pendidikan dan Kebudayaan Republik Indonesia mengeluarkan Surat Edaran Nomor 4 Tahun 2020 Pelaksanaan Kebijakan Pendidikan dalam Masa Darurat Penyebaran Coronavirus Disease yaitu pembelajaran dilakukan secara online di rumah masing-masing, dan proses belajar dari rumah melaksanakan dengan ketentuanketentuan salah satunya adalah pembelajaran daring bertujuan untuk pengalaman belajar yang bermakna bagi peserta didik. Oleh sebab itu, pembelajaran di tingkat satuan pendidikan dilaksanakan secara daring karena adanya Covid-19 sesuai dengan keputusan menteri pendidikan. Menurut Poon (2013) peserta didik memungkinkan saat pembelajaran daring untuk menjadi lebih termotivasi dan lebih terlibat dalam proses pembelajaran. Komitmen dan ketekunan peserta didik dapat ditingkatkan saat pembelajaran.

Pelaksanaan pembelajaran daring membutuhkan strategi pembelajaran yang didesain oleh pendidik. Menurut Warista (2018) strategi pembelajaran adalah adalah proses pemilihan dan penyusunan kegiatan dalam suatu unit pembelajaran seperti urutan, sifat materi, ruang lingkup materi, metode dan media yang paling sesuai. Bertujuan untuk mencapai kompetensi pembelajaran. Megawati (2020) memperoleh hasil bahwa strategi pembelajaran di era New Normal saat ini media sosial banyak digunakan seperti google classroom, whatsapp, zoom, dan e-learning. Media sosial digunakan agar dapat penyebaran virus Covid 19 dicegah khususnya di Indonesia.

Pembelajaran pendidikan jasmani pada tingkat satuan pendidikan dilakukan secara daring. Pendidik 
memiliki strategi dalam pembelajaran daring di era new normal yaitu menyiapkan bahan ajar berbasis digital, menggunakan aplikasi zoom, google meet atau aplikasi lainnya untuk pembelajaran tatap muka. Pendidik memberikan informasi pembelajaran menggunakan Whatsapp (WA) group, dan untuk pengumpulan tugas menggunakan google classroom dan email. Hal ini akan membantu proses pembelajaran dan tetap dapat berinteraksi antara pendidik dan peserta didik walaupun tidak dapat bertemu secara langsung di sekolah. Pemilihan strategi pembelajaran pendidikan jasmani disaat pembelajaran dari yang tepat dapat memberikan kemudahan antara pendidik dan peserta didik dalam mencapai tujuan pembelajaran.

\section{A. Pembahasan}

Pembelajaran daring saat pelaksanaan mempertimbangkan dengan kondisi yaitu mahasiswa dan dosen. Hal ini akan terbiasa disesuaikan dengan sistem daring, pembelajaran dapat dilaksanakan dengan baik, selain itu sistem daring memberikan pengalaman tambahan bagi mahasiswa sebagai calon guru di masa depan (Jamaludin, 2020).

Hasil penelitian diperoleh bahwa dosen kebanyakan memiliki strategi untuk melakukan pembelajaran new normal dengan cara kuisioner dipersiapkan dan membuat suatu video dengan bahan ajar. Hal ini bertujuan membantu mahasiswa agar materi dapat dipahami yang telah disampaikan oleh dosen melalui zoom (Nisa \& Anim, 2020). Hasil penelitian menunjukan bahwa pembelajaran daring aplikasi permainan digunakan sangat efektif saat pembelajaran. Mahasiswa merasa senang dengan adanya metode pembelajaran permainan sehingga menambah wawasan mahasiswa. Adanya sistem pembelajaran berbasis permainan, 
membuat mahasiswa merasa tidak bosan (Handriyantini, 2020).

Berdasarkan hasil penelitian yang terdahulu bahwa strategi pembelajaran saat daring dapat memanfaatkan aplikasi yang tersedia secara online. Bahan ajar yang sudah disiapkan oleh pendidik didesain secara digital sehingga dapat diakses oleh peserta didik saat pembelajaran. Pemilihan aplikasi yang efektif digunakan selama proses pembelajaran yaitu aplikasi yang tidak membutuhkan kuota yang besar dan dapat menampung peserta menyesuaikan jumlah peserta didik.

\section{B. Penutup}

Berdasarkan pembahasan dapat disimpulkan bahwa strategi dalam pembelajaran pendidikan jasmani berbasis daring di era new normal sangat penting untuk dapat mencapai tujuan pembelajaran. Pendidik dapat menyiapkan bahan ajar secara digital yang dikemas dengan menarik dan dapat mudah diakses oleh peserta didik. Selain itu, strategi pembelajaran yang dilakukan guru dengan memilih aplikasi yang tidak membutuhkan kuota yang besar dan menyesuaikan dengan jumlah peserta didik.

\section{Referensi}

Handriyantini, E. (2020). Strategi Pembelajaran Daring Aktif, Kreatif dan Menyenangkan. Malang: Seribu Bintang.

Jamaluddin, D., Ratnasih, T., Gunawan, H., \& Paujiah, E. (2020). Pembelajaran daring masa pandemik Covid-19 pada calon guru: hambatan, solusi dan proyeksi. $L P 2 M$. 
Megawati, M. M. (2021). Strategi Pembelajaran Di Era New Normal. Al-Ulum: Jurnal Pendidikan Islam, 1(3).

Nisa, K., \& Anim. (2020). Refleksi Dan Strategi Pembelajaran Melalui Media Daring Pada Era New Normal. Proseding Seminar Nasional Multi Disiplin Ilmu, Universitas Asahan., 134-138.

Poon, J. (2013). Blended Learning: An Institutional Approach for Enhancing Students' Learning Experiences. MERLOT Journal of Online Learning $\begin{array}{llll}\text { and } & \text { Teaching, } 9 & \text { (2). }\end{array}$ (http://jolt.merlot.org/vol9no2/poon_0613.pdf), diakses tanggal 9 februari 2017.

Pusdiklat Kemdikbud. (2020). SURAT EDARAN MENDIKBUD NO 4 TAHUN 2020 TENTANG PELAKSANAAN KEBIJAKAN PENDIDIKAN DALAM MASA DARURAT PENYEBARAN CORONA VIRUS DISEASE (COVID- 1 9) - Pusdiklat Pegawai Kementerian Pendidikan dan Kebudayaan. Https://Pusdiklat.Kemdikbud.Go.Id/.

Rahadian, A. (2020). INOVASI TEKNOLOGI PEMBELAJARAN PENJAS DALAM JARINGAN PADA MASA PANDEMIK COVID-19.Bunga Rampai, 29.

Warsita, B. (2018). STRATEGI PEMBELAJARAN DAN IMPLIKASINYA PADA PENINGKATAN EFEKTIVITAS PEMBELAJARAN. Jurnal Teknodik, 13(1), 064-076. 
198 | Akademisi dalam Lingkaran Daring 


\section{TIPS DAN TRIK MENGAJAR MATA KULIAH PRAKTIK (PEMBELAJARAN SENAM) SELAMA PANDEMI}

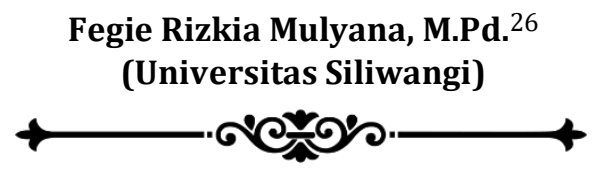

"Upaya yang dilakukan untuk tetap bisa menyampaikan konten perkuliahan dengan tidak menghilangkan makna tujuan pembelajaran selama pembelajaran daring, yaitu dengan cara menyederhanakan konten pembelajaran senam, mendesain pembelajaran semenarik dan semudah mungkin, Menentukan Platform yang digunakan, Evaluasi belajar yang menitikberatkan kepada proses dan upaya yang dilakukan siswa/mahasiswa"

$\mathrm{T}$ ahun 2020 merupakan awal perubahan bagi dunia pendidikan khususnya di Indonesia. Merebaknya Virus Covid-19 berdampak pada semua sektor dan

${ }^{26}$ Penulis lahir di Garut, 12 Juni 1989, penulis merupakan Dosen Universitas Siliwangi dalam bidang ilmu Pendidikan Jasmani, penulis menyelesaikan gelar Sarjana Pendidikan Jasmani, Kesehatan, dan Rekreasi di Universitas Siliwangi (2012), sedangkan gelar Magister Pendidikan Olahraga diselesaikan di Universitas Negeri Jakarta Program Studi Pendidikan Olahraga (2015). Penulis aktif dalam organisasi keolahragaan, baik olahraga prestasi dan olahraga rekreasi. Penulis juga aktif sebagai anggota di Asosiasi Pelatih Mental Olahraga Indonesia (APMOI). 
tatanan kehidupan. Akibat dari pandemi tersebut pendidikan di Indonesia mengalami evolusi baik dari segi teknis maupun dalam tatanan kebijakan pembelajaran. Teknis pembelajaran pun dilaksanakan secara daring (dalam jaringan), dengan kondisi tersebut Dosen harus mampu beradaptasi, berinovasi terlebih harus bisa menaklukan tantangan dan tuntutan yang menjadi kewajiban sebagai seorang instructor. Disatu sisi tujuan pembelajaran (kognitif, afektif dan psikomotor) harus tercapai, disisi lain dengan keadaan seperti ini sulit rasanya harus menyampaikan mata kuliah praktik jika melalui platform online.

Berdasarkan bukti empiris saat perkuliahan berlangsung begitu banyak kendala yang dialami, seperti terbatasnya pengetahuan dosen dan mahasiswa ihwal penggunaan platform pembelajaran online, , jaringan, apalagi permasalahan yang datang dari mahasiswa itu sendiri dengan berbagai alasan yang beragam salah satunya seperti kurang stabilnya jaringan di daerah mereka masing-masing. Hal ini sejalan dengan hasil penelitian yang diungkapkan (Azhari\&Fajri, 2021) yaitu,

Kendala yang dihadapi guru saat proses pembelajaran jarak jauh diantaranya sulit untuk mengimplementasikan pendekatan dan metode pembelajaran karena sebagian guru tidak dapat secara langsung memanfaatkan dan mengoperasikan berbagai Teknologi Informasi dan Komunikasi (TIK) seperti platform pembelajaran online yang banyak tersedia dalam mendukung pelaksanaan jarak jauh. Faktor lain seperti keterbatasan ekonomi orang tua, akses internet yang terbatas, dan tidak adanya panduan.

Mata kuliah Pembelajaran Senam merupakan mata kuliah utama Jurusan Pendidikan Jasmani, Universitas 
Siliwangi dengan bobot 0-2 Sistem Kredit Semester. Adapun capaian pembelajaran mata kuliah (CPMK) yaitu mampu merumuskan pengetahuan terkait pembelajaran senam, serta mampu mempraktikkan berbagai teknik dasar senam lantai dan senam menggunakan alat. Konten pembelajaran yang disuguhkan meliputi seputar senam artistik (Artistic Gymnastics). Menurut (Werner,2012) senam secara umum dapat didefinisikan sebagai latihan fisik di lantai atau pun menggunakan peralatan yang meningkatkan daya tahan, kekuatan, kelenturan, kelincahan, koordinasi, dan kontrol tubuh. Ada beberapa nomor atau alat dalam disiplin senam kompetitif, untuk Artistik Putera terdapat 6 (enam) alat seperti : nomor lantai (floor exercise), meja lompat (vaulting table), kuda pelana (pommel horse), palang sejajar (parallel bars), gelang-gelang (rings), dan palang tunggal (horizontal bars).

Sedangkan Artistik Puteri terdapat 4 alat yaitu: nomor lantai (floor exercise), meja lompat (vaulting table), balok keseimbangan (balance beam), dan palang bertingkat (uneven bars). Senam yang diajarkan baik di jenjang Sekolah Dasar, Sekolah Menengah Pertama, Sekolah Menengah Atas, dan Perguruan Tinggi dinamakan senam kependidikan. Senam kependidikan merupakan senam yang diterapkan pada kegiatan proses belajar mengajar (PBM) dengan sasaran utama untuk mencapai tujuan pendidikan.(Mahendra, 2000). Konten pembelajaran senam mengalami perubahan selama masa pandemi, hal tersebut berkaca pada keputusan Menteri Pendidikan dan Kebudayaan Republik Indonesia Nomor 719/P/2020 tentang Pedoman Pelaksanaan Kurikulum pada Satuan Pendidikan dalam Kondisi Khusus. Pelaksanaan kurikulum pada kondisi khusus bertujuan untuk memberikan fleksibilitas bagi satuan pendidikan untuk 
menentukan kurikulum yang sesuai dengan kebutuhan pembelajaran peserta didik. (Kepmendikbud, 2020). Kami pun sebagai team teaching di mata kuliah pembelajaran senam menyederhanakan konten perkuliahan disesuaikan dengan kebutuhan dan kondisi saat pandemi.

Kendala yang dirasakan saat pembelajaran senam secara daring, yaitu; (1) mata kuliah senam merupakan mata kuliah praktik, (2) keterampilan dalam pembelajaran senam merupakan teknik dasar sampai teknik yang kompleks, (3) mata kuliah senam memerlukan pendampingan dan pertolongan saat melakukan tugas gerak, (4) memerlukan peralatan atau sarana yang cukup sulit dan langka untuk dicari, tidak semua daerah atau sekolah mempunyai peralatan senam, seperti matras tebal, meja lompat, dll.

Upaya yang dilakukan untuk tetap bisa menyampaikan konten perkuliahan dengan tidak menghilangkan makna tujuan pembelajaran selama pembelajaran daring, yaitu dengan cara:

1. Menyederhanakan konten pembelajaran senam

Konten pembelajaran senam hanya disampaikan 70\% dari konten pembelajaran saat luring. Materi yang terlampau kompleks dan memerlukan sarana yang lengkap tidak dimasukkan ke dalam konten pembelajaran. Hal tersebut akan menghambat proses pembelajaran dan akan menyulitkan mahasiswa dalam mengerjakan setiap tugas gerak. Materi senam yang menggunakan alat disampaikan secara pengenalan dan bahasan teoretis serta diharapkan mahasiswa mampu menganalisis teknik gerak dalam materi tersebut. Capaian pembelajaran yang diharapkan hanya sebatas ranah kognitif saja. 
2. Mendesain pembelajaran semenarik dan semudah mungkin

Proses perkuliahan dirancang agar tidak memberatkan mahasiswa, baik materi yang disampaikan setiap pertemuan, tingkat kesulitan tugas, serta masa tenggat tugas. Selain itu usahakan meminimalisasi pertemuan maya seperti penggunaan zoom cloud meeting, bukan berarti membatasi akan tetapi untuk menekan cost yang dikeluarkan mahasiswa terkait penggunaan kuota. Disarankan pertemuan ke-1 s.d pertemuan ke-3 (sesuaikan dengan kebutuhan) menyampaikan materi yang bersifat teoretis untuk menunjang dan mengantarkan pemahaman mahasiswa dalam menerima materi selanjutnya. Setiap pertemuan zoom di sesi akhir pembelajaran, berikan tes formatif sebanyak sepuluh soal untuk mengetahui sejauh mana pemahaman mahasiswa dalam menyimak materi yang disampaikan. Materi perkuliahan sebelumnya sudah disiapkan/diunggah dalam kanal youtube (Fegie Rizkia Mulyana - YouTube), materi yang bersifat praktik alangkah baiknya ditugaskan melalui classroom dengan mentautkan link video yang terintegrasi dengan channel youtube, menekankan dan meng-explore pengetahuan mahasiswa agar mampu menganalisis teknik dasar gerak, mampu menjelaskan pengertian teknik tersebut dan mampu mendeskripsikan cara melakukan teknik tersebut.

Setiap intruksi tugas yang disampaikan di classroom usahakan menggunakan kata-kata persuasif, memotivasi, menantang, dan disampaikan secara jelas. Setiap informasi perkuliahan dan intruksi tugas Dosen sampaikan 
melalui Whats App Group dan membagikan melalui flyer yang di desain sedemikian rupa agar menarik minat mahasiswa. Tugas yang sudah disampaikan, kemudian dibahas dan di diskusikan dalam pertemuan maya (zoom) yang terintegrasi live streaming ke kanal youtube, hal ini dimaksudkan untuk mendokumentasikan perkuliahan agar suatu saat mahasiswa bisa melihat dan mengulang kembali materi yang disampaikan, serta sebagai share pengetahuan dan informasi kepada masyarakat maya. Teknis pembahasan tugas memalui zoom dengan menampilkan cuplikan video teknik dasar, dan cara menolong teknik dasar tersebut dilengkapi dengan teks penjelasan (pengertian, deskripsi gerak, kesalahan umum, dan teknik menolong).

3. Menentukan Platform yang digunakan

Begitu banyak LMS (Learning Management System) yang bisa kita temukan dan gunakan dalam proses pembelajaran daring, akan tetapi semua itu kembali kepada Dosen sebagai pengguna aplikasi tersebut. Platform mana yang lebih representatif dan mudah digunakan baik oleh dosen juga mahasiswa. Adapun platform yang digunakan dalam perkuliahan daring pembelajaran senam yaitu: (1) Zoom cloud meeting, untuk menyampaikan kajian teoretis perkuliahan, merefleksi dan mengevaluasi tugas gerak yang diberikan kepada mahasiswa, (2) Google Classroom, untuk mentransfer dan menggunggah material perkuliahan seperti kontrak perkuliahan, bahan ajar, tugas, soal UTS dan UAS, selain itu sebagai media dalam mengumpulkan tugas mahasiswa baik berupa dokumen ataupun video. Ketika mahasiswa mengumpulkan tugas praktik dalam bentuk video, 
usahakan durasi video tidak terlalu panjang, hal tersebut agar lebih mengefisienkan waktu kita dalam mengevaluasi tugas mahasiswa. Kenyamanan yang Penulis rasakan dalam menggunakan classroom sebagai media pengumpulan tugas, yaitu kita bisa lebih mobile dalam mengevaluasi tugas, bisa kapan pun dan dimana pun. Berbeda dengan googleform kita harus terpaku disatu tempat dan harus menggunakan laptop sebagai perangkat dalam memeriksa tugas, belum lagi harus menyediakan sheet seperti Ms.Excel untuk merekap nilai yang kita berikan ke mahasiswa (3) Youtube, sebagai platform video online untuk mengintegrasikan konten perkuliahan yang dilaksanakan lewat zoom sekaligus sebagai referensi mahasiswa agar bisa mengulas kembali apa yang telah kita sampaikan saat perkuliahan, (4) Googleform, sebagai platform untuk mengisi presensi perkuliahan, menyampaikan dan mengelola tes formatif dan soal-soal UTS dan UAS. Adapun aplikasi lain sebagai pendukung untuk mengemas konten dan informasi terkait perkuliahan agar semenarik mungkin yaitu Wondershare Filmora 9 untuk editing video konten pembelajaran dan Canva untuk membuat flyer sebagai alat informasi ke mahasiswa.

4. Evaluasi belajar

Penilaian lebih menekankan pada proses bukan hasil atau keterampilan yang dicapai. Artinya kita harus lebih menghargai usaha mahasiswa dibanding hasil keterampilannya. Karena dari setiap mahasiswa berbeda kemampuan dan keadaan baik lingkungan keluarganya maupun keadaan ekonominya. Pandai-pandailah menjadi motivator bagi mereka, posisikan kita bukan hanya 
sebagai pengajar saja, melainkan sebagai pendidik yang mengajarkan mereka sikap disiplin, tanggungjawab, menghargai waktu, diri sendiri dan orang lain melalui strategi pembelajaran yang kita terapkan (pola pemberian tugas, tepat waktu dalam menyerahkan tugas, kesesuaian tugas dengan intruksi yang disampaikan).

\section{DAFTAR PUSTAKA}

Agus Mahendra. 2000. Senam. Yogyakarta: Departemen Pendidikan Nasional.

Budi Azhari \& Iwan Fajri 2021. Distance learning during the COVID-19 pandemic: School closure in Indonesia. International Journal of Mathematical Education in Science and Technology. DOI: 10.1080/0020739X.2021.1875072.

KEPMENDIKBUD Nomor 719/P/2020. Pedoman Pelaksanaan Kurikulum Pada Satuan Pendidikan Dalam Kondisi Khusus. 7 Agustus 2020. Menteri Pendidikan dan Kebudayaan Republik Indonesia. Jakarta Pusat.

Werner, H.P. 2012. Teaching Children Gynmastics. United States: Human Kinetic. 


\title{
EVALUASI PEMBELAJARAN PJOK MELALUI PORTFOLIO ASSESMENT DI MASA PANDEMI
}

\author{
Andi Fepriyanto, M.Pd. ${ }^{27}$ \\ (STKIP PGRI Sumenep)

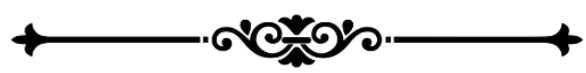

"Penilaian yang dapat kita gunakan dalam pembelajaran PJOK di masa pandemi ini dapat menggunakan penilaian portofolio assesment atau penilaian fortofolio, yang tetap menilai aspek kognitif, afektif dan psikomotorik"

$\mathrm{I}^{\mathrm{n}}$

mbas adanya pandemi covid-19 atau yang biasa disebut juga dengan virus corona salah satunya adalah pendidikan. Pendidikan dari jenjang taman kanak-kanak sampai perguruan tinggi dilakukan pembelajaran jarak jauh (PJJ), bahkan sampai semester ganjil tahun ajaran baru 2020-2021 proses pembelajaran masih tetap menggunakan pembelajaran dari rumah. Hal ini sesuai dengan surat edaran Menteri Pendidikan dan Kebudayaan yang telah dikeluarkan

27 Penulis lahir di Sumenep, 07 Februari 1989, penulis merupakan Dosen STKIP PGRI Sumenep dalam bidang ilmu Pendidikan Jasmani Kesehatan dan Rekreasi, penulis menyelesaikan gelar Sarjana Pendidikan Jasmani dan Kesehatan di Universitas Negeri Malang (2011), sedangkan gelar Magister Pendidikan diselesaikan di Universitas Negeri Surabaya Program Studi Pendidikan Olahraga (2014). Menjadi Asesor Pelatih Olahraga sejak (2015) di bawah naungan BNSP LSP-POR. 
yaitu Nomor 4 Tahun 2020 yang mengatur tentang Pelaksanaan Kebijakan Pendidikan dalam Masa Darurat Penyebaran Covid-19. Pembelajaran daring/online merupakan hal baru bagi sebagian sekolah yang ada di indonesia khususnya sekolah sekolah yang berada di daerah pedesaan dan plosok desa. Namun hal ini harus dilakukan agar pendidikan tetap berjalan meskipun dilakukan dari rumah masing-masing. Sehingga dibutuhkan inovasi serta pendekatan-pendekatan baru dan metode pembelajaran yang sesuai dengan pembelajaran daring/online.

Pembelajaran daring adalah pembelajaran jarak jauh yang cara pengantaran bahan ajar dan interaksinya dilakukan dengan perantara teknologi internet (Agus sumantri dkk. 2020: 6). Meskipun tidak semua sekolah dan daerah memiliki akses internet yang bagus namun secara umum berdasarkan hasil penelitian yang dilakukan oleh Ali Sadikin dkk (2020:220) pembelajaran daring efektif untuk mengatasi pembelajaran yang memungkinan dosen dan mahasiswa berinteraksi dalam kelas virual yang dapat diakses dimana saja dan kapan saja. Pembelajaran yang dilakukan secara online dari rumah masing masing membuat siswa dapat belajar lebih mandiri. Namun yang menjadi kekurangan dari pembelajaran daring yaitu guru tidak bisa mengawasi kegiatan pembelajaran yang dilakukan dari rumah masing-masing, sehingga butuh kerja sama dengan orang tua agar pembelajaran yang dilakukan lebih maksimal.

Pembelajaran Pendidikan Jasmani Olahraga dan Kesehatan (PJOK) merupakan pembelajaran yang lebih banyak menekankan pada aspek psikomotor atau keterampilan gerak dan dilakukan dilapangan. Berbeda dengan mata pelajaran yang lainnya yang dilakukan di dalam kelas dan menekankan pada aspek kogitif atau 
pengetahuan. Depdiknas (2006:131) mengartikan pendidikan jasmani olahraga dan kesehatan merupakan satu mata ajar yang diberikan di suatu jenjang sekolah tertentu yang merupakan salah satu bagian dari pendidikan keseluruhan yang mengutamakan aktivitas jasmani dan pembinaan hidup sehat untuk bertumbuh dan perkembangan jasmani, mental, sosial dan emosional yang serasi, selaras dan seimbang. Sehingga jika pembelajaran yang dilakukan adalah pembelajaran online atau daring maka pembelajaran harus disesuaikan begitu juga dengan evaluasi atau penilaian yang dilakukan. Sehingga tujuan pembelajaran tetap tercapai.

Aspek-aspek yang digunakan dalam penilaian pembelajaran PJOK terdiri dari tiga aspek sama hal nya dengan mata pelajaran lainnya yaitu aspek kognitif, afektif dan psikomotor dalam kurikulum K-13 menggunakan istilah pengetahuan, sosial dan keterampilan. Istilah yang digunakan berbeda namun maknanya tetap sama. Penilaian sendiri merupankan proses pengumpulan dan pengolahan informasi untuk mengukur pencapaian hasil belajar peserta didik dalam ranah sikap (spiritual dan sosial), ranah pengetahuan, dan ranah keterampilan yang dilakukan secara terencana dan sistematis, selama dan setelah proses pembelajaran suatu kompetensi muatan pembelajaran untuk kurun waktu tertentu (Nurdin, Ahmad. 2019:1). Penilaian yang dapat kita gunakan dalam pembelajaran PJOK di masa pandemi ini menyesuaikan dengan pembelajaran daring/online yang dilakukan maka penilaian yang dapat digunakan yaitu portofolio assesment atau penilaian fortofolio.

\section{Penilaian Afektif/ Sosial}

Penilaian Afektif dalam pembelajaran PJOK merupakan bagian dari hasil proses belajar melalui 
gerak. Pembelajaran PJOK tidak hanya belajar bergerak tapi juga belajar melalui gerak sehingga sikap sikap yang dipelajari dilakukan penilaian melalui observasi. Penilian afektif dalam pendidikan jasmani seharusnya juga dilakukan secara objektif seperti penilaian kognitif dan psikomotor (Winarno, 2014:162). Sikap-sikap yang dipelajari melalui gerak diantaranya tanggung jawab, sportivitas bekerjasama, percaya diri, disiplin, menghargai dan tolong menolong dan sikap sosial lainnya menyesuaikan dengan KI dan KD yang muncul.

Adanya pandemi covid-19 yang tidak memungkinkan pembelajaran dilakukan secara tatap muka namun dilakukan secara daring/online maka penilaian afektif tidak semua sikap dapat dinilai karena tidak dapat diamati atau diobservasi secara langsung yang dapat dilakukan guru yaitu menilai sikap-sikap yang ada seperti kedisiplinan siswa mengumpulkan tugas, rasa tanggung jawab dari siswa serta guru juga dapat menjalin kerjasama dengan orang tua di rumah untuk mengamati sikap-sikap selama di rumah. Berikut tahapan yang dapat guru lakukan dalam penilaia sikap selama pandemi covid-19.

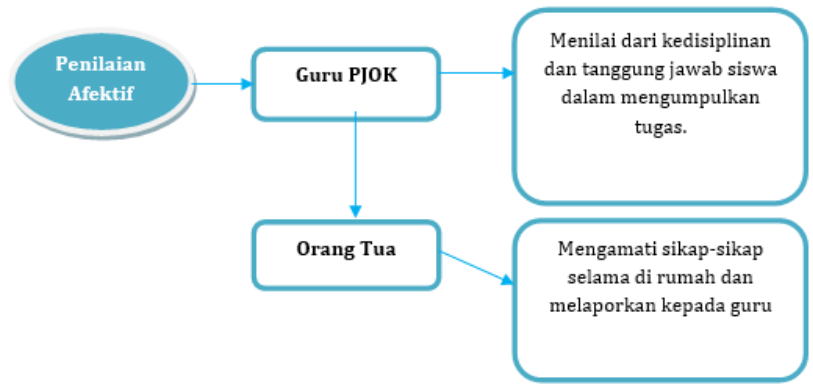

Gambar 1. Skema Penilaian Afektif 


\section{Penilaian Kognitif/ Pengetahuan}

Penilaian kognitif atau pengetahuan merupakan panilaian yang dilakukan untuk mengetahui seberapa jauh pemahaman siswa terhadap pembelajaran PJOK yang sudah terlaksana. Penilaian ranah pengetahuan dilakukan melalui berbagai teknik, antara lain tes tulis (pilihan ganda beralasan, isian), tes lisan, penugasan, dan portofolio (Nurdin, Ahmad. 2019:9). Dalam pembelajaran daring banyak pilihan yang dapat kita gunakan dari quiz secara online atau memberikan penugasan dan portofolio. Namun tidak semua tempat dan wilayah memiliki akses internet dan memiliki smartphone yang bagus sehingga guru harus menyesuaikan dengan lingkungan tempat kerja. Sehingga guru dapat memilih dan menyesuaikan berikut skemah penilaian kognitif pembelajaran PJOK di masa pandemi covid-19.

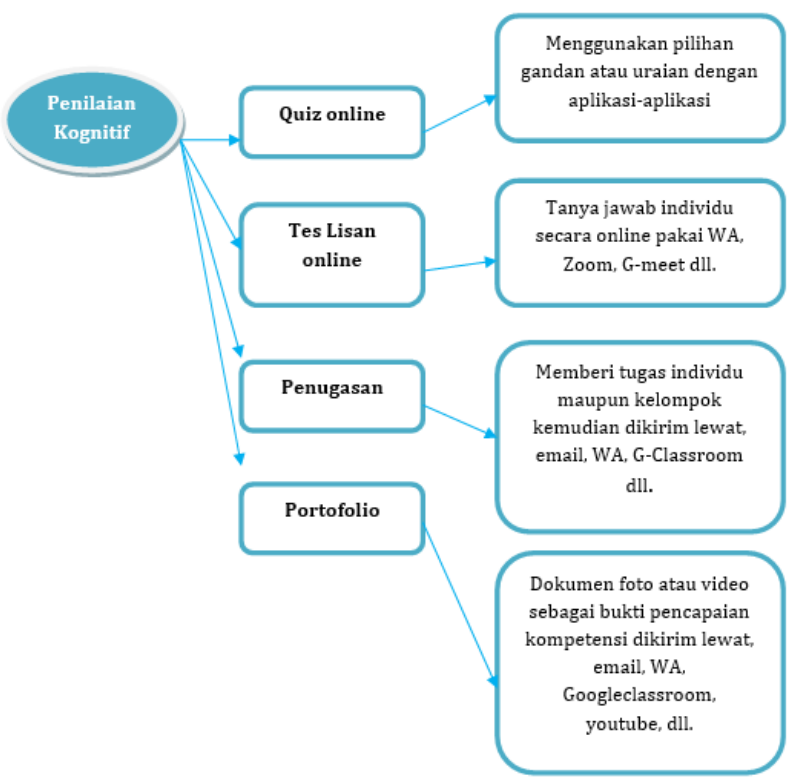

Gambar 2. Teknik Penilaian Kognitif 


\section{Penilaian Psikomotor/ Keterampilan}

Penilaian Psikomotor atau keterampilan menjadi penilaian yang utama dalam pembelajaran PJOK karena pembelajaran PJOK secara khusus merupakan pembelajaran yang dilakukan melalui gerak tubuh. Sehingga penilaian yang dilakukan merupakan peilaian psikomotor. Hasil penelitian yang dilakukan oleh Taufik dkk (dalam Winarno, 2006: 17) menyebutkan bahwa bobot penilaian yang diinginkan guru PJOK memiliki komposisi psikomotor 48,27\%, Kognitif 22,91\% dan Afektif 26,52\%. Sehingga penilaian Psikomotor merupakan penentu dari tinggi rendahnya hasil evaluasi pembelajaran siswa. Penilaian keterampilan cenderung pada kemampuan fisik dalam melakukan gerakangerakan teknik dasar suatu cabang olahraga yang telah dipelajari sesuai dengan KD. covid-19 memaksa kita untuk melakukan pembelajaran jarak-jauh (PJJ) sehingga guru PJOK sempat kebingungan bagaimana cara menilai aspek psikomotor karena biasanya dilakukan tes keterampilan secara langsung setiap individu maupun kelompok. Namun seiring berjalannya waktu guru dapat melakukan penilaia psikomotor dengan portofolio.

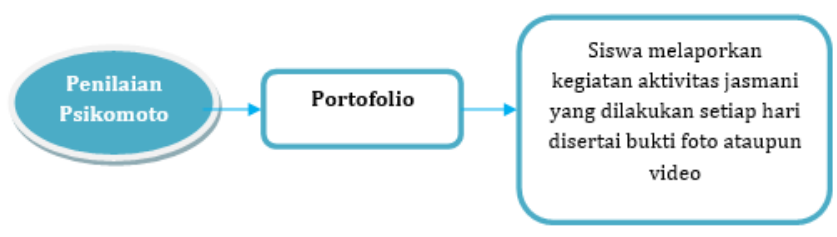

Gambar 3. Teknik Penilaian Psikomotor 


\section{DAFTAR PUSTAKA}

Agus Sumantri dkk. 2020. Booklet Pembelajaran Daring. Jakarta: Direktorat Jenderal Pendidikan Tinggi Kemdikbud RI.

Ali Sadikin dan Afreni Hamidah. 2020. Pembelajaran Daring di Tengah Wabah Covid-19 (Online Learning in the Middle of the Covid-19 Pandemic). Jurnal Ilmiah Pendidikan Biologi ISSN 2580-0922 (online), ISSN 2460-2612 (print) Volume 6, Nomor 02, Tahun 2020, Hal. 214-224 Available online at: https://onlinejournal.unja.ac.id/biodik.

BNSP. 2006. Ruang Lingkup Penjasorkes. Jakarta: Depdiknas.

Depdiknas. 2006. Permendiknas.No.22 tentang Tujuan Pendidikan Jasmani Olahraga dan Kesehatan. Jakarta: Depdiknas.

Nurdin, Ahmad. 2019. Peningkatan Mutu Penilaian Perencanaan Pembelajaran Berbasis Hots (High Order Thinking Skill) Materi: Analisis Penilaian Hasil Belajar. Bandung: Kementerian Pendidikan dan Kebudayaan R.I Direktorat jenderal guru dan tenaga kependidikan.

Winarno, M.E. 2014. Evaluasi Hasil Belajar Pendidikan jasmani Olahraga dan Kesehatan. Malang: Universitas Negeri Malang. 
214 | Akademisi dalam Lingkaran Daring 


\title{
IMPLEMENTASI PERMAINAN TRADISIONAL RAB-KERRABEN SAPE DALAM MENINGKATKAN MOTORIK SISWA DI MASA PANDEMI
}

\author{
Arief Wildan Jufri, S.Pd ${ }^{28}$ \\ (SDN Pangarangan III Kec. Kota Sumenep)

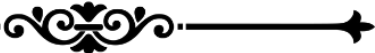

"Permainan tradisional Rab-Kerraben Sape dapat diimplementasikan pada pembelajaran PJOK di sekolah dasar sesuai dengan kompetensi dasar 4.2

Mempraktikkan kombinasi gerak dasar jalan, lari, lompat, dan lempar melalui permainan/olahraga yang dimodifikasidan atau olahraga tradisional"

\footnotetext{
Dandemi Virus corona atau Covid-19 sudah satu tahun lebih melanda negera-negara di dunia dari negara maju maupun negara berkembang. Virus yang pertama di temukan di negara China dengan cepat menyebar dan meluas hampir kurang lebih dari 216 negara dengan jumlah pasien yang positif sebanyak

28 Penulis lahir di Sumenep, 23 Juli 1988, penulis merupakan guru PJOK di SDN Pangarangan III Kecamatan Kota Sumenep, penulis menyelesaikan gelar Sarjana Pendidikan Jasmani dan Kesehatan di Universitas Negeri Malang pada tahun 2010 dan menyelesaikan Pendidikan Profesi Guru (PPG) di Universitas Negeri Malang pada tahun 2018.
} 
8.844.171 orang dan pasien yang meninggal sebanyak 465.460 orang akibat terjangkit corona virus tersebut (Organization World Health 2020), di Indonesia sendiri total yang terkonfirmasi positif terkena covid-19 adalah sebanyak 46.845 orang dan korban meninggal sebanyak 2.500 orang (covid19 2020) dan terus bertambah setiap harinya. Begitu mudahnya virus covid-19 ini menyebar maka dari perkantoran, sekolah, mall dan tempat liburan di tutup oleh pemerintah. Seluruh kegiatan dilakukan Work From Home (WFH) atau bekerja dari rumah tanpa terkecuali juga sekolah, guru harus mengajar dari rumah masing-masing dan murid melakukan belajar dari rumah (BDR). Selain itu pemerintah indonesia melalui satgas covid-19 juga mewajibkan 3M (mencuci tangan dengan sabun, memakai masker, menjaga jarak) untuk seluruh rakyat indonesia kapanpun dan dimanapun berada. Memang tidak mudah untuk melakukan hal-hal seperti di atas menjadi kebiasaan baru di masa new normal. Meskipun vaksinasi sudah berjalan namun kewaspadaan kita terhadap penyebaran virus covid-19 jangan sampai lengah dan kendor karena yang kita hadapi makhluk kecil yang tidak nampak oleh mata telanjang.

Kegiatan belajar dari rumah (BDR) atau dikenal juga dengan istilah pembelajaran daring merupakan pembelajaran online yang dilakukan dengan menggunakan tatap maya ataupun aplikasi-aplikasi media sosial yang ada saat ini, seperti wa, zoom, googleclassroom, youtube dan aplikasi yang lainnya digunakan guru dalam membantu atau menunjang pembelajaran online selama pandemi virus covid-19 ini. Berdasarkan penelitian yang dilakukan oleh Oktafia Ika Handarini dan Siti Sri Wulandari (2020:502) menyimpulkan bahwa pembelajaran daring merupakan salah satu solusi untuk menerapkan social distancing guna mencegah mata rantai penyebaran wabah covid- 
19, sehingga dapat menghindari kerumunan yang dianggap sebagai salah satu cara untuk menerapkan social distancing. namun meskipun demikian siswa harus di dukung dengan kemampuan telpon-telpon pinter dan akses internet yang mendukung. Kemampuan laptop dan telepon pintar untuk mengakses internet memungkinkan pelajar untuk mengikuti kegiatan belajar mengajar yang dilaksanakan dalam bentuk konferensi video maupun yang dilaksanakan dalam kelas-kelas online menggunakan layanan aplikasi-aplikasi pembelajaran yang tersedia secara online (Kay \& Lauricella dalam Firman \& Sari, 2020:83).

Pembelajaran PJOK di sekolah dasar merupakan salah satu pembelajaran yang dapat meningkatkan motorik atau gerak dan kebugaran jasmani siswa, sekalipun pembelajaran dilakukan secara daring namun guru PJOK harus tetap memperhatikan aspek psikomotor atau keterampilan dalam pembelajaran yang menjadi ciri khas pembeda dari matapelajaran yang lain dan juga agar membantu menjaga kondisi imun tubuh siswa sehingga terhindar dari virus covid19. Pembelajaran PJOK yang dilakukan secara daring butuh kerja sama dengan orang tua agar tetap mengawasi kegiatan pembelajaran yang dilakukan dari rumah. Perkembangan motorik siswa sekolah dasar sangatlah penting karena usia anak sekolah dasar merupakan masa-masa pertumbuhan dan perkembangan motorik anak usia sekolah dasar. Perkembangan motorik merupakan perkembangan dari segala bentuk perubahan yang terjadi secara progresif pada kemampuan anak untuk dapat melakukan berbagai gerakan yang diperoleh melalui interaksi antara faktor kematangan (maturation) dan latihan atau pengalaman (experiences) selama kehidupan yang dapat dilihat melalui perubahan/pergerakan yang 
dilakukan (Hascita Istiqomah dan Suyadi, 2019:166167). Perkembangan motorik terdiri dari motorik halus dan motorik kasar. Perkembangan motorik halus terdiri dari aktiivtas gerak yang melibatkan otot-otot kecil dengan koordinasi anggota tubuh seperti mata dan tangan. Sementara motorik kasar sendiri terdiri dari aktivitas gerak tubuh yang lebih kompleks yang meliputi keseimbangan, koordinasi antar anggota tubuh seperti berlari, melompat. Perkembangan motorik halus dan motorik kasar untuk usia anak sekolah dasar sangat banyak dipengaruhi oleh aktivitas ligkungan yang menunjang maka dari itu pembelajaran PJOK di sekolah dasar sangatlah berperan dalam meningkatkan perkembangan motorik siswa.

Karakteristik siswa sekolah dasar yang menjadi kebutuhan mereka salah satunya adalah senang bermain. Masa anak-anak adalah masa yang seharusnya menyenangkan dan masa yang dipenuhi dengan kegembiraan, banyak waktu yang digunakan untuk bermain dengan berbagai permainan yang menyenangkan (Komainan, Anton. 2019:125). Sehingga menuntut guru untuk merancang pembelajaran yang menyenangkan sambil bermain. upaya apapun yang dipilih dan dilakukan oleh guru dan perancang pembelajaran jika tidak bertumpu pada karakteristik perseorangan siswa sebagai subjek belajar, pembelajaran yang dikembangkannya tidak akan bermakna bagi siswa (Nevi Septianti \& Rara Afiani. 2020:16). Sehingga melalui permainan terutama permainan tradisional dari berbagai suku dan budaya yang ada di Indonesia dalam pembelajaran PJOK di sekolah dasar dapat digunakan utuk meningkatkan motorik siswa sekaligus melestarikan seni dan budaya bangsa indonesia. 
Indonesia memiliki keberagaman seni dan budaya yang menjadi kekayaan tersendiri bagi bangsa ini. Tak terkecuali dengan Pulau Madura yang sampai saat ini masih terus melestarikan kerapan sapi. Tentu kita tahu bahwa perlombaan kerapan sapi yang menjadi daya tarik bagi penonton adalah kecepatan berlari dari sapi tersebut. Hal ini menjadi motivasi bagi anak-anak di Pulau Madura untuk bisa beraksi layaknya sapi yang mampu berlari kencang.

Berawal dari kerapan sapi inilah terdapat permainan tradisional madura yang biasa mereka sebut permainan ini dengan sebutan rab-kerraben sape karena mengadopsi dari tardisi kerapan sapi di madura. Permainan ini dapat dimainkan oleh 3 (tiga) orang pada masing-masing kelompoknya. Dua orang bertugas sebagai sapi yang saling berpegangan dan seorang lainnya berada ditengah berperan sebagai joki. Dengan salah satu kaki diangkat dan kedua tangan memegang bahu temannya, mereka berlari sekencang mungkin mencapai garis finish yang telah ditentukan sebelumnya. Kelompok yang terlebih dahulu menyentuh garis finish dialah pemenangnya.

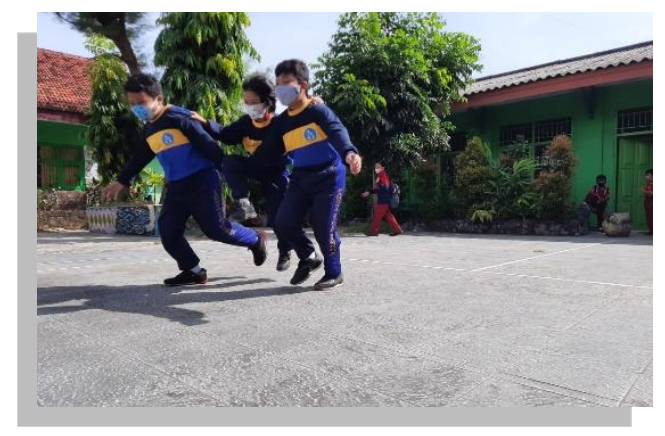

Gambar 1. Permainan Rab-Kerrapan Sape

(sumber: Dokumen Pribadi) 
Permainan rab-kerraben sape ini biasa dimainkan anak-anak pada waktu pagi ataupun sore hari. Rumahrumah di madura sangat terkenal dengan istilah "tanian lanjang" atau halaman yang panjang karena kekerabatan orang madura yang sangat erat maka mereka mendirikan rumah-rumah yang berjejer dan memiliki halaman yang panjang sehingga halaman rumah ini dapat mereka jadikan sebagai lintasan permainan tradisional rab-kerraben sape. Tanpa harus ke lapangan mereka dapat menyiapkan berbagai atribut yang bisa digunakan ketika memainkan permainan ini. Salah satunya adalah menggunakan kaleng bekas yang terlebih dahulu dilubangi dan diisi dengan kerikil untuk menghasilkan bunyi-bunyian untuk menambah semarak ketika berlari. Kaleng tersebut dikalungkan kepada joki dengan daun pisang yang kering atau tali rafia sebagai pengikatnya.

Permainan tradisional Rab-Kerraben Sape dapat diimplementasikan pada pembelajaran PJOK di sekolah dasar sesuai dengan kompetensi dasar 4.2 "Mempraktikkan kombinasi gerak dasar jalan, lari, lompat, dan lempar melalui permainan/olahraga yang dimodifikasi dan atau olahraga tradisional". Tujuan dari permainan ini adalah selain untuk melestarikan budaya lokal Madura, dari segi fisik juga dapat meningkatkan kebugaran dan kecepatan anak yang merupakan bagian dari perkembangan motorik siswa sekolah dasar. Sedangkan dari segi sosial dapat melatih kerjasama, kepedulian antar sesama dan mempererat tali persaudaraan. Namun tetap dalam pengawasan orang tua di rumah. Karena dilakukan di halaman rumah sendiri dan dengan kerabat sendiri maka orang tua lebih mudah mengawasi aktivitas siswa tentunya dengan tetap memperhatikan protokol kesehatan yang diterapkan. ${ }^{* * *}$ 


\section{DAFTAR PUSTAKA}

Firman \& Sari. (2020). Pembelajaran Online di Tengah Pandemi Covid-19. Indonesian Journal of Educational Science (IJES), Volume 02 No 02.

Hascita Istiqomah dan Suyadi. 2019. Perkembangan Fisik Motorik Anak Usia Sekolah Dasar dalam Pembelajaran (Studi Kasus pada SD Muhammadiyah Karangbendo Yogyakarta). :Jurnal PGMI Vol.11 No.2 Desember 2019 p. 155 168

website: http://journal.uinmataram.ac.id/index.php/elmi dad p-ISSN 2087-8389 e-ISSN 2656-4289.

Komainan, Anton. 2019. Kemampuan Motorik Anak Usia Dini. Depok : PT Rajagrafindo Persada.

Nevi Septianti \& Rara Afiani. 2020. Pentingnya Memahami Karakteristik Siswa Sekolah Dasar Di Sdn Cikokol 2. As-Sabiqun: Jurnal Pendidikan Islam Anak Usia Dini Volume 2, Nomor 1, Maret 2020; https://ejournal.stitpn.ac.id/index.php/assabiqu n.

Oktafia Ika Handarini dan Siti Sri Wulandari, 2020. Pembelajaran Daring Sebagai Upaya Study From Home (SFH) Selama Pandemi Covid 19. Jurnal Pendidikan Administrasi Perkantoran (JPAP) Volume 8, Nomor 3, E-ISSN: 23389621. 
222 | Akademisi dalam Lingkaran Daring 


\title{
TEKNIK PRAKTIS BELAJAR PENJASORKES DI MASA PANDEMIC 19
}

\author{
Dr. Idris Moh. Latar, S.Pd, M.Pd. ${ }^{29}$ \\ (Program Studi Penjaskesrek FKIP Unpatti)

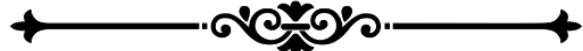

"Teknik Kolaboratif group grid dan teknik Pembelajaran POE Predict Observe Explaint menekankan siswa untuk belajar dengan mengembangkan dan menemukan pengetahuan penjasorkes yang selaras dengan pengetahuan yang dimiliki siswa"

Dandemic covid 19 telah memberi dampak yang kurang baik terhadap pelaksanaan pembelajaran penjasorkes. Pelaksanaan pembelajaran penjasorkes di sekolah idealnya memfasilitasi proses pembelajaran gerak dan keterampilan gerak yang relevan dengan tujuan pembelajaran. Suryobroto (2004:8) menjelaskan beberapa tujuan dari pendidikan jasmani yang terkait dengan pembentukan kemandirian siswa buat kehidupan di masa depan mulai dari kecerdasan fisik, nilai atau sikap, keterampilan motorik dan keterampilan gerak dasar. Hal ini perlu disikapi oleh pendidik namun

29 Penulis lahir di Banda Ely, 19 Mei 1974 Maluku. Menempuh pendidikan S1 Olahraga di FKIP Uhalu 2001, S2 Manajemen Olahraga UNJ 2009, dan S3 Doktor Pendidikan Olahraga di UNJ 2017. Mengabdi sebagai Dosen ASN di FKIP, Program Studi Pendidikan Jasmani Kesehatan dan Rekreasi UNPATTI dari tahun 2003- sampai sekarang 
fakta di lapangan menunjukan bahwa pembelajaran penjasorkes belum terlaksana sebagaimana mestinya. Di tambah dengan kondisi covid yang secara langsung merubah tatanan dan pola pembelajaran yang ideal yang dilaksanakan guru. Hal ini berdampak secara signifikan terhadap kualitas guru. Hasil temuan Taqwim dkk (2020) dalam pelaksanaan pembelajaran guru masih jarang melakukan kegiatan evaluasi pembelajaran pada saat penutupan yang dialihkan menjadi waktu pergantian seragam menuju tahap persiapan mengikuti kegiatan pembelajaran selanjutnya dan tidak adanya kegiatan pendinginan yang dilakukan oleh seorang guru pendidikan jasmani kesehatan dan lahraga kepada siswa. Pelaksanaan pembelajaran, guru hendaknya meningkatkan kreatifitas, mengembangkan kurikulum, menigkatkan kompetensi, mengembangkan kegiatan pembelajaran yang sesuai dengan silabus, mengenal karakteristik peserta didik dan memanfaatkan sarana di sekolah dan lingkungan dan melakukan evaluasi pembelajaran guna meningkatkan hasil pembelajaran siswa.

Guru dalam pelaksaaan pembelajaran perlu memperhatikan ketercapian tujuan pembelajaran yang dapat membentuk karater dan menjadi contoh yang baik bagi siswa (Darmawati et al, 2017). Aspek-aspek yang terkait dengan kelengkapan berkas pembelajaran perlu di persiapkan dengan baik oleh guru seperti RPP, Media, metode, teknik pembelajaran dan lain-lain. Pambudi (2019) menjelaskan tiga aspek yang harus menjadi perhatian ketika pelaksanaan pembelajaran pendidikan jasmani yaitu kegiatan pendahuluan, inti dan penutup. Aspek-aspek ini perlu di perhatikan dengan baik oleh guru mulai dari perencanaan, pelakasanaan dan evaluasi. 
Pembelajaran penjasorkes seyogyanya dilakukan harus memprhatikan teknik-teknik yang sesuai sehingga sehingga aktifitas pembelajaran penjasorkes sesuai dengan tujuan pembelajaran. Banyak teknik pembelajaran yang dapat digunakan guru dalam aktifitas pembelajaran penjasorkes. Namun keterbatasan pengetahuan dan pengalaman guru penjasorkes selama ini masih terpaku pada pola pembelajaran yang menekannkan pada model ceramah, mendemonstrasikan yang berdampak terhadap minat dan kemauan siswa dalam pembelajaran penjasorkes. Hal ini perlu disikapi dengan baik salah satunya adalah menerapkan teknik-teknik pembelajaran yang praktis.

\section{A. Pembahasan}

\section{Teknik Pembelajaran Penjasorkes}

Teknik pembelajaran adalah cara-cara yang digunakan guru dalam pembelajaran penjasorkes. Banyak defenisi tentang teknik pembelajaran yang dikemukan oleh ahli, namun semuanya dirangkum dalam makna yang sama bahwa teknik berkaitan dengan cara atau usaha yang dilakukan yang melibatkan banyak aspek pendukung yang relevan dengan kebutuhan pembelajaran. Konsep teknik dari Sanjaya (2010), Joni dalam Abimayu (2018) menjelaskan bahwa teknik merupakan implementasi yang spesifik daari metode yang terkait erat dengan potensi atau kemampuan guru dalam melaksanakan pembelajaran yang ada hubungan dengan kondisi awal atau latar, adanya sarana dan prasarana yang mendukung, kemampuan dan kesiapan siswa dalam melaksanakan pembelajaran. Dalam melaksanakan teknik pembelajaran penjasorkes guru sebaiknya memperhatikan tujuan dan ketersedian unsure pendukung lainnya seperti sarana untuk melakukan 
aktiftas berbagai permainan sebagaimana yang tercantum dalam kurikulumnya.

Lain lagi dengan pendapat yang dikemukan oleh Sudjana (2005) yang menekankan pada aspek gabungan antara seni dan keterampilan yang dilakukan secara sistematis. Sementara itu Gerlach dan Ely dalam Uno (2009) menjelaskan teknik adalah usaha atau jalan yang dilakukan guru yang terkait dengan alat dan media untuk mencapai tujuan pembelajaran. Dalam melaksanakan teknik pembelajaran guru perlu memperhatikan cara-cara yang tepat, efektif, dan efisien dalam pembelajarannya sehingga pembelajaran dapat dilaksanakan dengan lebih tepat dan akurat. Sehingga dengan demikian tujuan pembelajarannya dapat tercapai dengan baik dan relevan dengan kebutuhan institusi dan siswa.

Berdasarkan jabaran defenisi tentang teknik pembelajaran di atas dapat disimpulkan bahwa teknik berkaitan dengan kiat-kiat atau cara yang dapat dilakukan oleh seorang guru dalam aktifitas pembelajaran. Aktifitas ini harus memperhatikan banyak aspek mulai dari perencanaan-pelaksanaan-dan evaluasi. Pelaksanaan yang baik akan memberi dampak bagi kenyamanan dan motivasi siswa dalam belajar. Sehubungan dengan ini Suprihatiningrum (2016:158) menjelaskan beberapa unsure yang harus diperhatikan dalam teknik pembelajaran yaitu: (1) teknik merupakan implementasi dari metode, (2) jabaran operasional dari metode, dan (3) prosedur pelaksanaan kegiatan pembelajaran. Berdasarkan kisi-kisi ini guru dapat mengembangkan dan melaksanakan pembelajaran yang lebih terarah dan terstruktur secara sistematis.

\section{Teknik Pembelajaran Praktis}

Ada kata kunci utama dalam pelaksanaan teknik pembelajaran praktis yaitu; efektif dan efisien. Efektif 
dan efisien disini mengandung makna mudah diterapkan oleh guru dan siswa. Banyak teknik pembelejaran praktis yang dapat di terapkan guru dalam pembelajaran penjasorkes diantaranya adalah teknik pembelajaran kolaboratif dalam bentuk group grid dan Predict Observe Explaint. Masing-masing memiliki ciri khas dan penekanan yang berbeda. Masing-masing dijelaskan sebagai berikut:

a. Teknik Kolaboratif group grid.

Dalam teknik kolaboratif group grid siswa di arahkan untuk belajar penjasorkes dalam bentuk kelompok dengan teknik memberikan informasi yang terpotong-potong. Informasi inilah nantinya akan dikembangkan oleh siswa berdasarkan pengetahuan yang dimilikinya. Keaktiftan siswa menjadi penentu dalam kegiatan ini, siswa dapat berkolaborasi dengan siswa lainnya. Guru dalam hal ini mengarahkan siswa untuk saling berbagi informasi dan menyeleksi informasi yang sesuai. Adapun langkah-langkah teknik pembelajaran kolaboratif group grid adalah sebagai berikut: (1) membagi siswa dalam beberapa kelompok, 3-4,-5 dst, (2) memberikan atau menampilkan lembar yang kosong untuk di isi siswa bersama dengan anggita kelompoknya, menyampaikan kompetensi yang harus dikuasai siswa setelah pembelajaran, (4) memberikan kesempatan kepada tiap kelompok untuk menjelaskan kembali materi sekitar 5 menit, (5) meminta untuk siswa mengisi sel-sel kosong yang ada pada kisi, (6) masingmasing kelompok mendiskusikan isian dari sel-sel yang kosong, (7) mempresentasikan hasil diskusi kelompok, dan (8) menarik kesimpulan secara keseluruhan dan melakukan umpan balik terhadap kegiatan yang dilakukan selama aktifitas pembelajaran. 
b. Teknik Pembelajaran POE (Predict Observe Explaint)

Teknik pembelajaran ini menekankan pada penemuan, siswa di arahkan untuk menemukan atau mengembangkan pengetahuan berdasarkan pengetahuan dasar yang dimiliki siswa. Siswa dirangsang untuk aktif dalam berdiskusi. Warsono (2014:93) Teknik ini bertujuan untuk mengungkap kemampuan siswa dalam melakukan predict (prediksi), observe (pengamatan) dan Explaint (penjelasan). Dalam konsep pembelajaran konstruktivis pembelajaran yang terbaik dilakukan dengan mengarahkan siswa untuk menenukan dan mengembangkan pengetahuannya sendiri. Fungsi guru di sini hanya memfasilitasi agar aktifita ini dapat berjalan dengan baik. Dalam teknik POE setiap siswa harus akfit membangun pengetahuan tentang penjasorkesnya dengan baik. Contoh: guru memberikan arahan tentang berbagai macam olahraga permainan tradisional yang ada di lingkungan sekitar. Teknik ini akan berhasil dengan baik jika para siswa diberi kesempatan untuk mengamati, mengemukankan dan demonstrasi berbagai permainan tradisional sesuai dengan pengetahuan, pengalaman yang pernah di laluinya. Pengalaman dapat memberikan antaran kepada siswa untuk membangun pengetahuanya sehingga terciptalah ruang belajar yang tepat bagi siswa dan guru dengan demikian tujuan pembelajaran akan dapat tercapai dengan baik.

\section{B. Penutup}

Teknik pembelajaran praktis adalah teknik pembelajaran yang menekankan pada kemudahan siswa dalam pembelajaran penjasorkes. Indikator praktis disini adalah efektif, efisien, dan mudah untuk 
diterapkan oleh guru dan siswa dalam pembelajaran penjasorkes.

\section{DAFTAR PUST AKA}

Agus N Cahyo. 2013. Panduan Aplikasi Teori-Teori Belajar Mengajar Aktual dan Terpopuler, DIVA Press, Jogjakarta.

Abimanyu, Soli. dkk. 2008. Strategi Pembelajaran. Jakarta: Direktorat Jendral. Pendidikan Tinggi Departemen Pendidikan Nasional.

Darmawati, D,T. Rahayu, A. R., \& R.C. (2017). Leadership Guru Pendidikan Jasmani Olahraga dan Kesehatan di SMP Ogan Komering Ulu Timur Sumatera Selatan. Journal of Physical Education and Sports, 6(2), 108-116. Diambil dari https://journal.unnes.ac.id/sju/index.php/jpes/a rticle/view/17359.

Hamzah B. Uno. 2009. Model Pembelajaran (Menciptakan Proses Belajar Mengajar yang Kreatif dan Efektif, Jakarta: Bumi Aksara .

Pambudi, M. I., Winarno, M. \& Dwiyogo, W, D. (2019). Perencanaan dan Pelaksanaan Pembelajaran Pendidikan Jasmani Olahraga Kesehatan. Jurnal Pendidikan Olahraga, Universitas Negeri Malang, 4(1), 110-116. Diambil dari http://journal.um.ac.id/index.php/jptpp/

Slameto,.1991. Proses Belajar Mengajar dalam Sistem Kredit Semester (SKS), Jakarta: Bumi Aksara.

Sanjaya, Wina. (2010). Strategi Pembelajaran Berorientasi Standar Proses. Pendidikan. Jakarta : Prenada Media Group. 
Suprihatiningrum, Jamil. 2016. Strategi Pembelajaran Teori dan Aplikasi. Yogyakarta: Ar-Ruzz Media.

Taqwim R. I, Winarno, M, E. \& Roesdianto. (2020). Pelaksanaan Pembelajaran Pendidikan 144 Jasmani ,. Jurnal Pendidikan, 5(3), 395-401.

Warsono. 2014. Pembelajaran Aktif Teori dan Asesmen, PT Remaja Rosdakarya, Bandung, 


\title{
KESADARAN HUKUM , KESEHATAN MASYARAKAT DALAM AGAMA HINDU DI TENGAH PANDEMI COVID-19
}

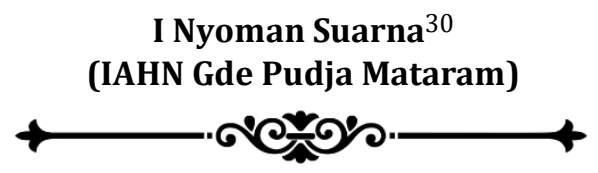

"Kedasaran hukum masyarakat yang dibangun secara kolektif untuk selalu mematuhi dan taat pada ajuran pemerintah untuk selalu mematuhi protokol kesehatan (Prokes) juga berada di luar rumah ini bentuk kesadaran dharma agama."

\begin{abstract}
Covid-19 adalah kondisi infeksi yang artinya dapat menyebar secara langsung atau tidak langsung dari satu orang ke orang lain. Infeksi ini meliputi ssaluran pernapsan atas (hidung, tenggorokan saluran udara, dan paru-paru. Disebabkan oleh Corona virus baru bernama novel corona virus, pertama kali diidentifikasi di Wuhan, China pada desember 2019 (buku panduan anti panik haladoc, $\mathrm{tt}: 10$ ). Covid-19 merupakan viris yang penyebaranya melelui udara, sentuhan, benda

${ }^{30}$ I Nyoman Suarna.,AMd.,SH.,MH Penulis lahir di pengendan, 31 Desember 1970,penulis merupakan dosen IAHN Gde Pudja Mataram dalam bidang hukum Hindu, menyelesaikan meyelesaian sarjana hukum Unram (1997)' gelar Diploma 3 Pendidikan Agama Hindu (2003) juga mengikuti Pendidikan AKTA IV FKIP Unram (2002) sedangkan Magister ILmu Hukum di Unram dengan peminatan Hukum pemerintahan (2010).
\end{abstract}


serta alat-lat lain yang dapat menghantarkan kepada manusia. Virus ini hampir sama dengan virus yang lain seperti TBC, DB, SARS dan MERS atau yang pernah seperti Plu Burung yang dapat mengakibatkan kematian jika penangan dan pengobatan tidak dilakukan secara maksimal.

Untuk itu perlu di jaga keseimbangan antara kegiatan fisik dan pikiran sehingga tubuh akan menjadi stabil dan pikiran akan berjalan seirama dan selaras demi untuk menjaga kesehatan. Jika kehidupan manusia diakaitkan dengan undang-udang kesehatan Pasal 1 poin 1 dalam undang-undang No. 36 tahun 2009 tentang Kesehatan ditegaskan "Kesehatan adalah keadaan sehat, baik secara fisik, mental, spritual maupun sosial yang memungkinkan setiap orang untuk hidup produktif secara sosial dan ekonomis". Dengan demikian keseimbangan hidup itu secara hukum negarapun memberikan perlindungan agar setiap warganegara untuk dapat menjaga kesehatan baik untuk diri sindiri (fisik) mental, juga spiritual serta juga menjaga kesehatan lingkungan dimana tempat tinggal baik fisk, biologis maupun sosial dan ekonomi.

Secara sosial, setiap individu harus dapat hidup produktif bersama individu yang lain untuk menjaga keharominisan dengan lingkungan dan alam semesta, juga dapat menjaga ketahanan ekonomi kelurga dan anggota masyarakat dengan membangun kesadaran sosial secara bersama dalam melawan wabah covid-19 ini. Dari pemaparan diatas" Bagaimana kesadaran Hukum dan kesehatan masyarakat dalam Hindu dalam menyikapi pandemi covid-19 dewasa ini". 


\section{A. Pembahasan}

\section{Pandangan Hindu terhadap wabah covid-19 dan kesehataan.}

Hindu memandang segala bentuk kejadian yang terjadi didunia ini memang tidak ada sesuatu kebetulan, akan tetapi sudah ada yang mengatur yaitu Maha Kuasa yaitu Brahman (Tuhan yang Maha Esa). Sehingga manusia sebagai mahkluh yang tertinggi yang memiliki kecerdasan serta kebijaksanaan harus dapat menjaga alam beserta isinya. Alam yang kita tempati ini merupakan titipan yang perlu di jaga dan dirawat agar dapat digunakaan untuk kelangsungan mahluk hidup dimuka bumi ini. Hindu memandang manusia merupakan satu keluarga "Wasudhaiwa kutumbakam". Hal ini ditegaskan dalam ajaran Tri Hita Karana, yaitu ada 3 (tiga) penyebab dunia ini menjadi harmonis dan serasi. Pertama menjaga keharonisan dengan parahyangan meluai bhakti kepada Brahaman (Tuhan) sebagai penyebab dari terciptanya dunia beserta isinya, melalui berbagai cara untuk mengagungkan kebesaran Brahman (Tuhan) seperti berdoa serta bersembahyang, berdana punia (bersedekah), dewa yadnya serta melaksanakan ajaran dan menjauhi larangan, kedua berhubungan yang harmonis dengan pawongan (manusia), artinya hidup dengan manusia yang lainnya. Ketiga berhubungan harmonis dengan palemahan (alam lingkungan) yang ada disekitar tempat tinggal termasuk alam lingkungan untuk dapat digunakan sebagai sumber kehidupan baik bahan pangan dan papan.

Untuk dapat menjaga keharmonisan melelui penerapaan ajaran Tri Kaya parisudha yaitu wacika, manacika dan kayika. Jika dikaitkan dengan covid-19 dalam hindu dapat dikategorikan sebagai kuman atau gering dalam sastra hindu yang datang darai alam, maka perlu dilakukan pengobatan, yang dalam hindu dikenal 
dengan Ayur Weda. Untuk dapat menyebuhkan penyakit yang diakibatkan oleh kuman yang keberadaan tidak dapat dipantau secara kasat mata yang dapat ditimbulkan dari dalam dan dari luar dan dari dalam diri manusia sehingga menimbulkan stress, susah tidur sehingga semua itu terakumulaasi menjadi penyakit yang dapat merugikan diri manusia. Penyakit yang diakibatkan oleh alam, sperti keadaan cuaca dan pergantian musim, seperti sekarang kenal dengan Covid-19 atau juga di sebut dengan virus corona.

Untuk mengahadapi penyakit tersebut harus menjaga lingkungan tempat tinggal terjaga kebesihannya dengan melakukan mencuci tangan dengan sabun di air yang mengalir, jaga jarak, hindari kerumunan, memakai masker jika diluar rumah dan bepergian dan hindari kontak langsung dengan sesama, agar terhindar dari penyakit seperti covid-19 ini. Sedangkan penyakait yang ditimbulkan dari dalam diri manusia, perlu melakukan menjaga asupan makan yang cukup, jangan lupa mengkonsumsi vitamin, tidur yang teratur, menjaga kesehatan mental seperti jangan cemas menghadapai wabah ini, harus tetap tenang dan selalu mendekatkan diri dengan Tuhan dengan cara berdoa, persebahyangan dirumah dan mengikuti protokol kesehatan seperti bepergian keluar rumah menggunakan masker, mandi dengan menggunakan sabun serta teratur mengganti pakaian sehabis digunakan keluar rumah. Juga dapat melakukan terapi yang murah miriah seperti berjemur dibawah sinar matahari dipagi hari jam 10.00 selam kurang lebih 15 menit, juga sore hari sekitar jam16.00. hal ini dilakukan agar dapat memberikan energi bagi tubuh kita yang ditimbulkan oleh sinar matahari yang mengandung vitamin d yang dapat dijadikan pengobatan. 
Pengobatan dalam hindu sebagaimana ditegaskan dalam (Titib,1998 : 552) bahwa ilmu pengobatan meliputu keperawatan, pemeriksaan dan pengobatan, perawatan dengan api, air, udara, sinar matahari, sentuhan, yadnya, racun, kuman-kuman, perwatan dengan binatang dan dengan tumbuh-tumbuhan. Artinya Hindu sudah mengatur ilmu tentang pengobatan baik dalam bentuk medis termasuk terapi semua sudah diatur dalam ajar hindu hal ini sejalan dengan regulasi yang dikelurkan oleh pemerintah dalam bentuk undang-undang kesehatan No. 36 tahun 2009 tantang kesehatan. Untuk menjaga kesehatan juga perlu mendapatkan sinar matahari melalui berjemur di bawah sinar matahari pagi dan sore agar dapat meningkatkan metabolism tubuh. Juga sakit dapat menghubungi dokter untuk memeriksa penyakit agar dapat segera diambil tindakan perawatan serta pengobatan agar segera disembuhkan penyakit. Hal ini ditegaskan dalam Weda sebagai ditegaskan oleh (Titib, 1998) berikut ini "Yatrausadhih samagmata Rajanah samitav-iva Viprah saucyate bhisag Raksoha-ami vacatanah (Rgveda x.97.6) Artinya: sarjana yang mengumpulkan semua jenis tumbuhan- tumbuhan ramuan obat, menyembuhkan penyakit-penyakit dan membasmi kuman-kuman penyakit, dinamakan seorang perawat kesehatan (dokter) (Titib, 1998:552).

Mantra diatas menjelaskan bahwa untuk mengatur perawatan kesehatan yang kenal di dunia kesehatan yaitu Dokter yang akan merawat serta pengobatan termasuk didalam melakukan terapi agar pasien segera sembuh dari penyakit yang disebabkan oleh kuman seperti covid-19 ini. Juga dalam penyembuhan diperlukan waktu istirahat selama 14 hari agar masa inkubasi dapat berakhir pengoabatan covid-19, juga sejalan dengan standar WHO dan Kementrian kesehatan di Indonesia termasuk gugus covid-19 yang ada 
didaerah. Akan tetapi pengobatan cara hindu tidak saja dilakukan dengan medis, juga pengobatan melalui terapi seperti menggunakan sinar matahari yang dapat membasmi penyakit, akan tetapi Hindu pengobatan juga dilakukan melalui Yadnya yaitu melalui ritual atau upacara ini bentuk pengobatan secara holistik yang dilakukan dalam hindu dengan maksud untuk memohon kepada Brahman (Tuhan) agar wabah penyakit yang melanda manusia pada saat covid-19 ini agar segera menghilang, dan manusia dapat beraktifitas secara normal.

\section{Kesadaran Hukum Masyarakat di era Pandemi covid-19.}

Masyarakat dikejutkan oleh covid-19 ini, untuk dapat melekukan perubahan sosial terhadap kehidupan masyarakat yang semula selalu hidup secara komunal seperti kegiatan pendidikan, bersama perayaan keagaamaan secara masal, seminar, berwisata bersama keluarga, saling mengunjungi dengan sanak keluarga yang lain, mengunakan tranportasi umum baik darat, laut dan udara. Kesemua ativitas masyarakat yang dilakukan secara komunal tadi lagi dapat dilakukan, tantu akan membawa konskwensi yang berubah dimasyarakat, hal ini akan berdampak pada perekonomia sudah barang tentu akan terjadi perubahan sosial. Perubahan ini akan berimplikasi terhadap kebiasaan-kebiasaan masyarkat yang semula kehidupan normal menjadi perubahan pola kehidupan yang baru. Seiring dengan itu pemerintah mengeluarkan regulasi agar masyarakat dapat diatur demi menjaga keselamatannya. Pemerintah mengeluarkan PERPRES No. 82 Tahun 2020 tentang Komite Penanganan Corona Virus Disease 2019 (COVID-19) dan Pemulihan Ekonomi Nasional dan KEPPRES No. 9 Tahun 2020 tentang Perubahan atas Keputusan Presiden Nomor 7 Tahun 2020 tentang Gugus Tugas Percepatan 
Penanganan Corona Virus Disease 2019 (Covid-19). Gugus tugas ini mempunyai tujuan: a) meningkatkan ketahanan nasional di bidang kesehatan; b) mempercepat dan pemerintah daerah; c) meningkatkan antisipasi perkembangan eskalasi penyebaran covid-19; d) meningkatkan sinergi pengambilan kebijakan operasional; dan e) meningkatkan kesiapan dan kemampuan dalam mencegah, mendeteksi, dan merespons terhadap covid-19.

Penaganan covid-19 ini perlu juga diikuti oleh kesadaran dari masyarakat secara kolektif untuk bersama membangun kesadaran hukum bagi masyarakat untuk taat pada anjuran pemerintah untuk tetap dirumah, menggunakan masker jika melakukan bepergian, jaga jarak dengan orang lain, membiasakan mencuci tangan dengan sabun dan air yang mengalir, jika sakit segera ke dokter untuk memerikasakan diri, semua ini dilakukan demi dapat menjaga manusia yang lainnya.

\section{B. Penutup}

Pada era pandemic covid -19 masyarakat hindu harus sadar akan kekuatan Tuhan dalam menjaga kesehatan manusia melalui pengobatan secara Hindu baik medis, juga terapi termasuk juga melalaui yadnya dengan berdoa Kepada Tuhan juga pengobatan dapat dilakukan secara holistik atau dharma negara. Kedasaran hukum masyarakat yang dibangun secara kolektif untuk selalu mematuhi dan taat pada ajuran pemerintah untuk selalu mematuhi protokol kesehatan (Prokes) juga berada di luar rumah ini bentuk kesadaran dharma negara. 


\section{DAFTAR PUSTAKA}

Titib, 1998.Weda Sabda Suci Tuhan Pedoma Parktis Kehidupan. Paramita Surabaya.

Wang Zhou, MD, 2020. Buku Panduan Pencegahan Coronavirus 101 Tips Berbasis Sains Yang Dapat Menyelamatkan Hidup Anda. Penerjemah Shan Zhu, Qing Chen, Jun Li. Chief Physician of Wuhan Center For Disease Control and Prevention

Kementrian Kesehatan Republik Indonesia, tt, Menghadapi Covid-19: Buku Panduan Anti Panik dari \#TemanHidupSehat

Undang-undang No. 36 tahun 2009 tentang Kesehatan.

PERPRES No. 82 Tahun 2020 tentang Komite Penanganan Corona Virus Disease 2019 (COVID19) dan Pemulihan Ekonomi Nasional.

KEPPRES No. 9 Tahun 2020 tentang Perubahan atas Keputusan Presiden Nomor 7 Tahun 2020 tentang Gugus Tugas Percepatan Penanganan Corona Virus Disease 2019 (Covid-19). 


\section{AKA DEMISI \\ DALAM \\ DINEKARAN \\ DARING

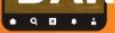

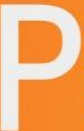

roses pendidikan yang sudah terbiasa dilakukan di sekolah dan perguruan tinggi harus mampu juga diwujudkan ketika harus belajar dari rumah. Kondisi ini tentu menjadi tantangan bagi profesi bidang pendidikan. Buku dengan judul "AKADEMISI DALAM LINGKARAN DARING" ini hadir tentunya untuk menjadi salah satu referensi bagaimana seharusnya para profesi bidang pendidikan menjalankan profesinya. Prediksi berbagai pihak bahwa belajar di rumah secara digital (online) diperkirakan relatif tidak dapat mewujudkan hasil belajar yang optimal, seperti diketahui bahwa hasil belajar di sekolah secara umum diukur melalui tiga domain yaitu kognitif (pengetahuan), psikomotor (keterampilan atau penguasaan gerak atau keahlian) dan afektif (perubahan sikap atau perilaku atau kharakter). Domain kognitif, afektif dan psikomotor diyakini masih dapat diwujudkan melátui online meskipun relatif kurang optimal hasil belajarnya.

Terobosan yang banyak disarankan melalui berbagai metode belajar daring (dalam jaringan) atau secara digital (online) di tengah badai Covid-19. Upaya untuk mempertahankan kualitas pendidikan yang diukur dari tingkat capaian hasil belajar di tengab Pandemi Covid-19 tentu menjadi target dari para penulis Bunga Rampairini yang dijabarkan dalam berbagai topik sebagaínana tututan kurikulum Merdeka Belajar di sekolah dimana ketiga domain tersebut saling terkait untuk mewujudkan capaian hasil belajar. Secara garis besar ukuran yang dapat digunakan dari tiga domain tersebut adalah meningkatnya pengetahuan murid-metalui apa yang dipelajari. Hal ini tidak luput dari pemikiran penulis untuk membahasnya sehingga buku Bunga Rampai menjadimenarik bagi setiap pembaca.

Akademia Pustaka

Perum. BMW Madani Kavling 16, Tulungagung

https://akademiapustaka.com/

redaksi.akademia.pustaka@gmail.com

f1@redaksi.akademia.pustaka

0]@akademiapustaka

081216178398
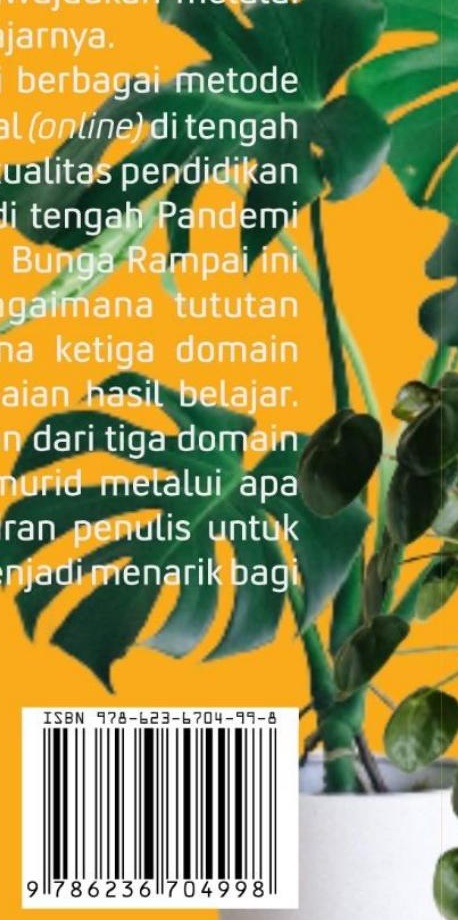